\title{
Data Preparation of the nuMoM2b Dataset
}

\author{
Anton Goretsky* $\quad$ Anastasia Dmitrienko ${ }^{\dagger} \quad$ Irene Tang $^{\ddagger} \quad$ Nicolae Lari $^{\dagger}$ \\ Owen Kunhardt* Raiyan Rashid Khan ${ }^{\dagger} \quad$ Cassandra Marcussen $^{\dagger}$ Adam Catto* \\ Daniel Mallia* Alisa Leshchenko* Adam (Yun Chao) Lin $^{\dagger} \quad$ Anita Raja*

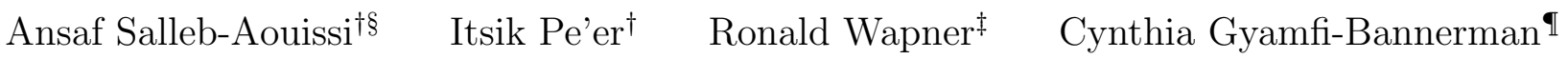

\begin{abstract}
In 2010, the Eunice Kennedy Shriver National Institute of Child Health and Human Development (NICHD) started the Nulliparous Pregnancy Outcomes Study: Monitoring Mothers-to-be (nuMoM2b), a prospective cohort study of a racially/ethnically/geographically diverse population of nulliparous women with singleton gestation. The nuMoM2b is a very large dataset, consisting of data for 10,038 patients with over 4,600 features per patient, spread out over 80 files. In this report, we share our experience preparing and working with this dataset. We present our data preprocessing of the nuMoM2b dataset to get a deeper understanding of the data, extract the most relevant features, make the fewest assumptions when filling in unknown values, and reducing the dimensionality of the data. We hope this report is useful to researchers interested in building machine learning and statistical models from the nuMoM2b dataset.
\end{abstract}

\section{Introduction to nuMoM2b and Data Processing}

The primary goal of the nuMoM2b study [1] was to determine the maternal characteristics, both clinical and genetic factors, physiological response to pregnancy and environmental factors that could be used to derive models that accurately predict adverse pregnancy outcomes (APOs). Our team has extensive prior experience working on medical data for preterm birth (PTB) prediction $[2,4,5]$.

As originally organized, the dataset is not immediately conducive to analysis to those unfamiliar with the medical background, nor is it conducive to quick placement into machine learning models. The ratio of instances to features would result in an inevitable model overfitting. Various medical categories exist within an individual file, data relevant to features exist throughout many different files, and dependencies and redundancies exist across the whole dataset. As such, nuMoM2b required extensive review and processing of features, their dependencies and relations in order to reduce the complexity of the dataset, and shape it in a form amenable to a variety of machine learning (ML) algorithms and exploratory data analysis (EDA).

The intended audience for this document is researchers interested in building machine learning and statistical models from the nuMoM2b dataset. Our aim is to share our experience preparing and working with this dataset. The intent is not to share the processed dataset nor the scripts that are specific to research aims.

Our specific research goal is to build machine learning models for the prediction and prevention of preterm birth in nulliparous women using the nuMoM2b dataset. This project is funded by the NIH/NLM (Project \# 1R01LM013327-01). The data review and processing work described in this document was conducted through the direct collaboration of the Computer Science departments at Hunter College and Columbia University, along with maternal and fetal medicine experts at the Columbia University Medical Center. The following are the goals of this collaborative effort:

- Significant reduction of the feature space for a better management of the data and a a reduction of the risk for overfitting.

\footnotetext{
${ }^{*}$ Department of Computer Science, CUNY Hunter College

$\dagger$ Department of Computer Science, Columbia University

$\ddagger$ Department of Obstetrics and Gynecology, Columbia University

$\S$ Contact author ansaf@cs.columbia.edu

IDepartment of Obstetrics, Gynecology, and Reproductive Sciences. UC San Diego Health Sciences
} 
medRxiv preprint doi: https://doi.org/10.1101/2021.08.24.21262142; this version posted August 26, 2021. The copyright holder for this preprint (which was not certified by peer review) is the author/funder, who has granted medRxiv a license to display the preprint in perpetuity.

It is made available under a CC-BY-NC-ND 4.0 International license .

- A reformatting of the dataset, to allow for easy configuration of the data, conducive to exploration and machine learning modeling.

- Extensive literature review of existing risk factors related to data categories and causal pathways of PTB.

- Exploratory data analysis of both the reduced and the unmodified feature space.

As a result of the effort, the dataset was reduced to 364 features at the most general level of complexity, and 465 features at a higher level of detail. Extensive filtering and imputation rules were created to accomplish this goal, along with a system for both human readability and easy script interpretation. An extensive literature review was performed documenting odds ratios. EDA was performed on the dataset, comparing calculated odds ratios to the literature review, and discovering and correcting data inconsistencies. Finally, we summarize our thoughts on data preprocessing and nuMoM2b in Section 7.

We summarize and visualize the PTB statistics in the dataset in Figure 1 and 2. See [3] for more details about the dataset.
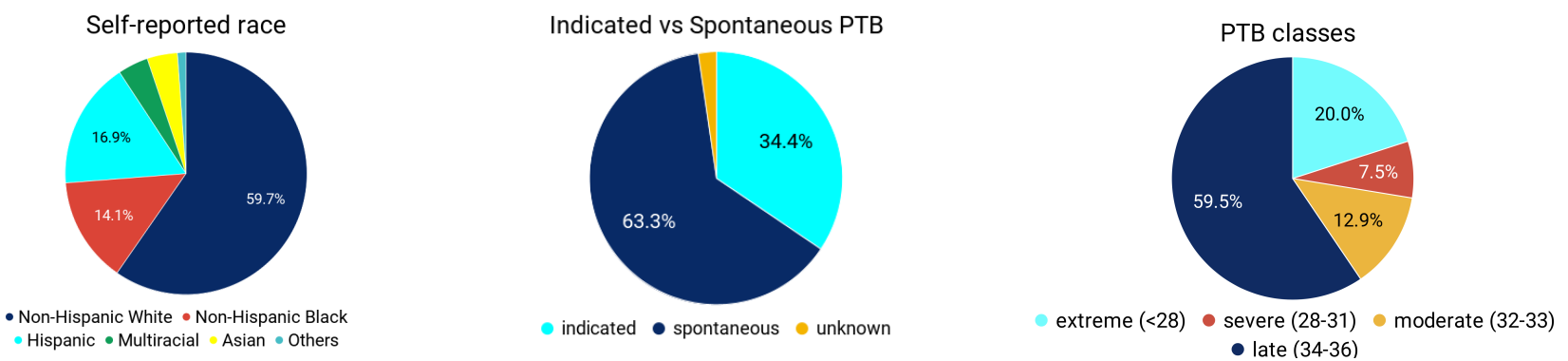

Figure 1: Preliminary statistics in the nuMoM2b data
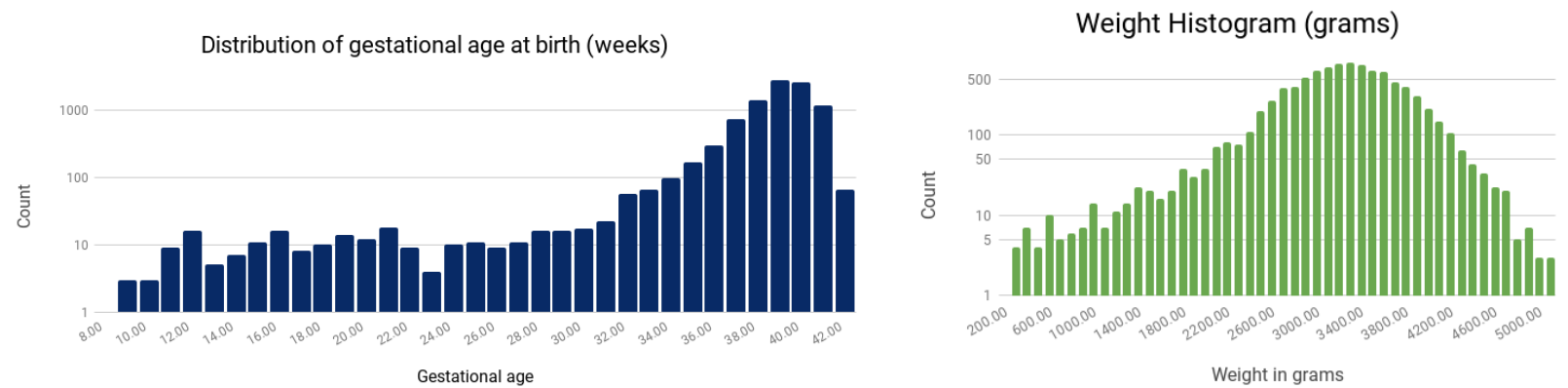

Figure 2: Distribution of gestational age and weight in the nuMoM2b data

\section{Preprocessing}

As part of the preprocessing stage, the information present in the provided codebooks on basic variable statistics, distribution, and type was transferred over via a script to a workable spreadsheet. Then to support our analysis, the following steps were taken:

- "Data type" was corrected to a more accurate label. Many variables were labeled "num" for numeric even though they actually represented categorical data. For example, Country of Birth (V1AF08) was labeled numeric. However, country cannot be treated as a numeric feature in modeling. Numeric, according to the codebook, simply meant the values used in labeling were numerals. This problem was repeated across the entire dataset. As such, each variable was looked at manually and categorized properly for typical modeling and analysis. Many variables labeled "num" were changed to "categorical". 
medRxiv preprint doi: https://doi.org/10.1101/2021.08.24.21262142; this version posted August 26, 2021. The copyright holder for this preprint (which was not certified by peer review) is the author/funder, who has granted medRxiv a license to display the preprint in perpetuity. It is made available under a CC-BY-NC-ND 4.0 International license .

- A "Missingness" metric was calculated using the variable statistics provided in the codebook to help with data analysis.

- A new "Temporal" label was added in order to label variables that appear at multiple unique time points throughout the study. nuMoM2b data was recorded at several distinct time points, and some variables are updated over time / questions are asked more than once. Temporal had values of True or False.

- A new "Temporal Detail" label was added in order to label at which time point a variable is relevant. Not all data collected are relevant only to the moment of collection in the study. For example, many demographic related questions were asked at Visit 2. However, those are static features and significant at all points in the study. This concept will be explained further under the section titled "Timeline".

Accuracy of action timing, such as treatment administration like medications, and the creation of these "temporal" labels are important for this team's goals of sequential treatment decision making modeling.

\section{Organization into Groups}

After the preprocessing stage, further organization was desired to better understand and manage the dataset. In order to better organize the data, Filtering Groups were created. The goal of these groups was to break down the dataset into more understandable portions for those unfamiliar with the detailed medical content, and for simpler processing of data in bulk. The following were the filtering groups created for the nuMoM2b dataset.

- Treatment - Variables relating to intervention in cases of potential or immediate PTB risk, such as progesterone administration, steroids, and last minute medical administrations at delivery.

- Psychological - Variables relating to the psychological state of the patient, through multiple scales.

- Physiological - Variables relating to instantaneous measurements of physiology, such as temperature, symptoms of flu-like illnesses, blood pressure, etc.

- Medical History - Variables relating to long term medical history and conditions, but also various tests performed on both the mother and the fetus or newborn found in the study.

- Demographics - Variables relating to the patient's demographic factors, such as race, income, education, etc.

- Ultrasound - Variables that were recorded from the research and clinical ultrasounds the patient went through and marked as such in the dataset.

- Outcomes - A metadata file containing various variables that are useful mainly as classifier labels, or are features that were collected post-delivery about the mother or newborn.

- Activity - Variables relating to the physical activity of the patient.

- Toxicology - Variables relating to the medications taken just before and during pregnancy, and / or their relations to particular reasons / conditions.

- Family History - Variables relating to family medical conditions and history.

- Food Frequency Analysis - Variables relating to food, diet and vitamins, in the three months prior to pregnancy.

- Sleep Substudy - Select variables from the two sleep substudies included in nuMoM2b. 


\section{Processing}

Now that the dataset was more simply organized, the process of feature reduction began. Filtering groups were divided among teams, who worked in consultation with the Columbia University Medical Center OB/GYN collaborators, to determine which features to keep as is, which features to summarize into scales, scores, or other aggregate forms, and which features to remove for redundancy or other reasons. As a result of this effort, a system was created to organize the efforts in a form both readable by people, and interpretable by scripts, to allow for easy updates. This system consists of the creation of Filtering and Imputation Rules, and Layering. Filtering rules serve to keep, drop, or summarize features, while imputation rules serve to impute missing data as required by many modeling algorithms. Layering served to organize the data into different levels of abstraction from the most general to the most specific level of information.

\subsection{Layers}

Layers were decided upon given the high feature complexity of nuMoM2b, even after much feature reduction. As many questions are structured around a format of a general question followed by several sub-questions, it was reasoned that the general question should in most cases be representative of the data points that follow. For example, V1AD06 asks, Have you had any 'flu-like illnesses', 'really bad colds', fever, a rash, or any muscle or joint aches since you became pregnant? This question is then followed by questions in regard to which symptoms are actually present in this 'flu-like illness'. V1AD06 covers all, and is such a more general question, and thus would be selected into a more general layer, while symptom specific questions would be reserved for the detailoriented layers, or dropped. If dropped, they may be brought back if desired, or if some significance is found in the most general feature. Internally, we decided upon 3 layers.

- Layer 0 would consist of known risk factors for PTB, along with variables shown to have high odds ratios in our EDA.

- Layer 1 would be the most general layer, consisting of L0 and all general questions that cover as much information as possible.

- Layer 2 would bring back detail that may have been lost, or not included given the generalization and simplicity of L0 and L1.

We will not go into variable-level detail in each layer, but we believe this concept can serve as an organizational method for large complex datasets.

\section{$4.2 \quad$ Filtering and Imputation Rules}

As part of the data cleaning process, data first passes through a general filtering script, with the rules shown in Table 1. It then passes through an imputation script, with the rules shown in Table 2. Throughout the processing of this dataset, we strived to hold to a set of generally applicable rules for imputation. Below is a sample of the imputation rules used for nuMoM2b.

- If a numeric-like feature is applicable to a vast majority of patients, and the missingness was relatively low, we attempted to impute with a value such as MEAN or MODE. If multiple measurements were made on the same information, the mean took into account all of them (excluding those marked as incomplete or inaccurate).

- If a feature serves as a general precursor to a list of follow-up questions, such as "Have you had any flu-like illnesses, 'really bad cold', fever, a rash..." followed by questions regarding symptoms, if data is present in the follow-up but the is missing for the general question, we impute the general question to whatever value represents True. Otherwise we often impute to an unknown or not applicable determiner such as 999, especially if assumption is misleading in the understanding of treatment. Often, these imputation rules looked at follow-up questions that were not included in the current layer or were excluded from modeling, due to the general question covering the topic. For the follow-up questions themselves, imputation may have been left at unknown or imputed to a value depending on the missingness and applicability.

- Negative one (-1) was often used to represent unknown or inapplicable for numeric features. 
Table 1: List of Filter Rules and their Descriptions

\begin{tabular}{|c|c|}
\hline Filter Type & Description \\
\hline TEMP & $\begin{array}{l}\text { Converts complementary Celsius and Fahrenheit temperature features } \\
\text { into one Fahrenheit feature }\end{array}$ \\
\hline WEIGHT & $\begin{array}{l}\text { Converts complementary LB and KG weight features into one LB fea- } \\
\text { ture }\end{array}$ \\
\hline ADD & Adds up given numeric features into one feature \\
\hline ONEHOT & Aggregates given binary features into one-hot vector \\
\hline MEAN & $\begin{array}{l}\text { Take the mean value across given numeric features and converts to one } \\
\text { feature }\end{array}$ \\
\hline GROUPCONDITION & $\begin{array}{l}\text { Categorizes } 9 \text { binary features corresponding to family history preva- } \\
\text { lence into } 3 \text { separate binary features: spontaneous, indicated, and fetal } \\
\text { conditions }\end{array}$ \\
\hline ALCSUM & $\begin{array}{l}\text { Combined drinking days/week and drinks/day into a single numeric } \\
\text { feature }\end{array}$ \\
\hline ALCSCALE1 & $\begin{array}{l}\text { Combines drinking days/week and drinks/day for one binary feature } \\
\text { representing }>7 \text { drinks per week }\end{array}$ \\
\hline CALC_POLYHYDRAMNIOS & Sum up the 4 quadrants \\
\hline WEEKSUM & $\begin{array}{l}\text { Converts three features (years, months, and weeks) into one weeks fea- } \\
\text { ture: } 52 * \text { years }+4 * \text { months }+ \text { weeks }\end{array}$ \\
\hline GROUPCOUNT & $\begin{array}{l}\text { Creates } 3 \text { scores among spontaneous, indicated, and fetal conditions for } \\
\text { family history risk factors by summing up the following prevalance: } 1 \\
\text { for mother, } 0.75 \text { for sister, } 0.5 \text { for half-sisters, } 0.25 \text { for cousins }\end{array}$ \\
\hline QUITSMOKE & $\begin{array}{l}\text { Combines smoking cessation features into a single binary feature for } \\
\text { attempted to quit smoking }\end{array}$ \\
\hline SECONDHAND & $\begin{array}{l}\text { Combines secondhand smoke exposure features into a single binary } \\
\text { yes/no feature for exposure }\end{array}$ \\
\hline SMOKESCALE & Creates 3 categories of cigarettes/day: $0 \mathrm{cpd}, 1$ to $19 \mathrm{cpd}$, or $20 \mathrm{cpd}$ \\
\hline DRUGSCALE & $\begin{array}{l}\text { Nonprescribed stimulants (cocaine, amphetamines), nonprescribed de- } \\
\text { pressants (narcotics, heroin all types), methadone (note this is not il- } \\
\text { licit), other nonprescribed (inhalants, hallucinogens) }\end{array}$ \\
\hline GEST_AGE & $\begin{array}{l}\text { Computes the average age of gestational loss for the first two pregnan- } \\
\text { cies }\end{array}$ \\
\hline SLEEP_AVG & $\begin{array}{l}\text { Computes the average hours of sleep per night combining across week- } \\
\text { days and weekends }\end{array}$ \\
\hline ADRENAL_MEASURE & $\begin{array}{l}\text { Computes adrenal gland measurements based on ultrasound data, ei- } \\
\text { ther averaging original and repeated measurements or using whichever } \\
\text { is available }\end{array}$ \\
\hline
\end{tabular}

- When there is parent feature and there are several related child features that are too detailed, DROP the child features.

\section{Timeline}

This timeline is meant to serve as a high level representation of the way we processed and organized data for internal analysis and modeling. This timeline does not cover all variables and is thus not an exhaustive representation of nuMoM2b. It serves rather as a quick glance into the data currently in use, accurate at time of publication, but subject to change. Each internal substudy may use a different collection of variables for their goals.

This timeline shows the existence of six unique time points that nuMoM2b represents. 5 of those time points are directly sequential, namely Before Pregnancy, Visit 1, Visit 2, Visit 3, Visit 4 (Delivery Visit), and Post Delivery. There also exists a Constant time point, which groups data that may have been collected at different points in the study, but applies at all times to the patient, such as race and pregnancy history. In an ideal full-term pregnancy, the patient would pass through all these time points, and have data recorded under the Constant point. However, if a birth was preterm, still, or a patient missed a visit, their timeline could skip some of either Visit 1, 2 or 3, and move straight to Visit 4, which represents data collected at delivery. This is represented 
medRxiv preprint doi: https://doi.org/10.1101/2021.08.24.21262142; this version posted August 26, 2021. The copyright holder for this preprint (which was not certified by peer review) is the author/funder, who has granted medRxiv a license to display the preprint in perpetuity.

It is made available under a CC-BY-NC-ND 4.0 International license .

Table 2: List of Imputation Rules and their Descriptions

\begin{tabular}{|l|l|}
\hline Imputation Name & Description \\
\hline MEAN & Imputes with the mean (average) of the existing values \\
\hline BMICAT & Imputes based on exising BMI \\
\hline ONEHOT & $\begin{array}{l}\text { Encodes current values by assigning each unique value to an index and } \\
\text { assigns a vector of zeros for missing values }\end{array}$ \\
\hline MULTI & $\begin{array}{l}\text { Imputes with a value of True if any of given features is present: False } \\
\text { otherwise }\end{array}$ \\
\hline SINGLE & $\begin{array}{l}\text { Imputes with a value of True if any of given features is present: False } \\
\text { otherwise (different internal organization, outcome same as ANY) }\end{array}$ \\
\hline NEG1 & $\begin{array}{l}\text { Imputes with a value of True if a given feature is present: False other- } \\
\text { wise }\end{array}$ \\
\hline NUMERIC & Imputes missing values with -1 \\
\hline MODE & Imputes missing values with the given numeric value \\
\hline SUM_LEQ & Imputes with the mode of the existing values \\
\hline
\end{tabular}

by the dashed arrow in the timeline. Variables in the timeline are organized by the Filtering Groups described earlier, and are abstractly summarized and simplified in the tables below. On the bottom right we see two boxed sections. These represent time points that occurred in between time points in this timeline. Antepartum evaluations may have occurred between visits, and enrollment screening occurred before visit 1. To reiterate, this timeline is not representative of all data available or used, but should rather serve as a quick guide.

Table 3: Amount of patients available at each visit. Present numbers are patients who filled out the main maternal interview form. Patients designated as other / missing may still have information available at that visit, especially under Chart Abstractions. Delivery outcomes are available for almost every patient except those withdrawn. Withdrawn patient counts were approximated using the interval at form A05 recording (official withdrawal). Other / Missing represents those not having taken the main maternal interview form, $(\mathrm{V} \# \mathrm{~A})$

\begin{tabular}{l|ccccc} 
& Visit 1 & Visit 2 & Visit 3 & Visit 4 (Delivery) & Post Delivery \\
\hline Present $(V \# A)$ & 10,028 & 9,412 & 9,217 & 7,167 & 9,430 \\
Withdrawn & 7 & 167 & 213 & 276 & 62 \\
Other or Missing & 2 & 407 & 489 & 2,595 & 608
\end{tabular}


medRxiv preprint doi: https://doi.org/10.1101/2021.08.24.21262142; this version posted August 26, 2021. The copyright holder for this preprint (which was not certified by peer review) is the author/funder, who has granted medRxiv a license to display the preprint in perpetuity.

It is made available under a CC-BY-NC-ND 4.0 International license.

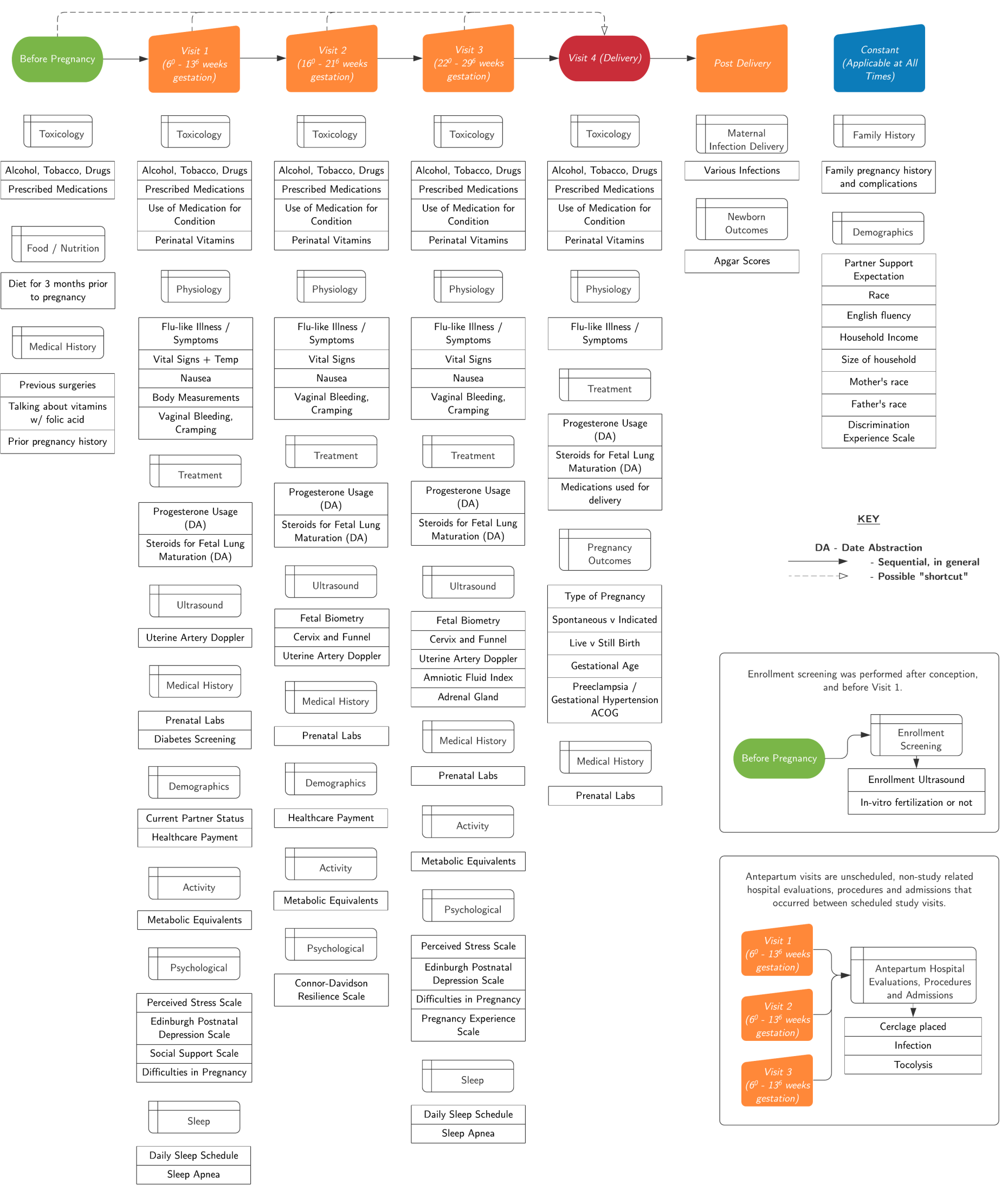

Figure 3: nuMoM2b Processed Data Timeline 


\section{$6 \quad$ Filtering Group Breakdown}

The following is a breakdown of the filtering groups our team decided upon at the time of writing. These groups are subject to change in name and organization, and simply serve to understand and organize the data in a simpler and more manageable fashion. Each group below contains a description of itself, the total number of features marked belonging to said group, the number of features used in layer 1 and layer 2, the files which comprise the group, and a general description of the features that were dropped from out modeling. Following each description, shown is a table of the features both compiled and used as-is. Features used as-is are at the top of the table. Compiled features - those constructed from other variables in the data - follow, and are surrounded by horizontal lines and bolded. Those below a compiled variable are used to construct it, using the rule listed next to the compiled feature. The column NAME represents the original or compiled variable name. FILE represents the file in the data from which the original feature comes from. RULE represents which filtering rule was used to compile a group of features. TEMPORAL represents at which point in the timeline this feature is relevant. TEMPORAL ranges from - 1 to 5, where 1 to 4 represent Visits 1 to 4 (delivery), -1 represents "applies at all time", 0 represents before pregnancy, and 5 represents post-pregnancy. IMPUTE represents which rule was used for imputation. MISSING represents the missingness value for each original feature. DESCRIPTION is a shortened description from the original data set of each variable.

\subsection{Family History}

The family history filtering compiled all of the questions regarding diagnoses of family members related to diabetes, blood clotting disorders, pregnancy complications, heart disease, and hypertension. The 9 pregnancy-related conditions were grouped into 3 categories:

Spontaneous

- Early or preterm rupture of the membranes

- Spontaneous preterm delivery (less than 37 weeks)

Indicated

- Delivery of a child more than 3 weeks before the expected due date

- Preeclampsia, eclampsia, toxemia or pregnancy-induced hypertension

Fetal Conditions

- Delivery of a child weighing less than 5 lb 8 oz (or 2500 grams)

- Stillbirth

- Delivery of an infant with a birth defect

- Other pregnancy complication

Layer 1 includes binary features indicating any presence of family history in the 3 categories. Layer 2 compiled a more detailed score in the 3 categories which aggregates a score based on the genetic proximity to the stated family member, based on the following scale: 1 for mother, 0.75 for sister, 0.5 for half-sisters or cousins.

Total \# Features: 113

Layer 1 \# Features: 3

Layer 2 \# Features: 3

Relevant Files: V2A

Dropped Features: We chose to discard family history related to diabetes, blood clotting disorders, heart disease, and hypertension, in order to focus on pregnancy-related conditions. Family history does NOT include the patient's own medical history. 
medRxiv preprint doi: https://doi.org/10.1101/2021.08.24.21262142; this version posted August 26, 2021. The copyright holder for this preprint (which was not certified by peer review) is the author/funder, who has granted medRxiv a license to display the preprint in perpetuity.

\section{It is made available under a CC-BY-NC-ND 4.0 International license .}

Table 4: Family History Filtering

\begin{tabular}{|c|c|c|c|c|c|c|}
\hline NAME & FILE & RULE & TEMPORAL & IMPUTE & MISSING & DESCRIPTION \\
\hline $\begin{array}{l}\text { V2A_spontaneous_risk, } \\
\text { V2A_indicated_risk, } \\
\text { V2A_fetal_condition_risk }\end{array}$ & $\mathrm{V} 2 \mathrm{~A}$ & GROUPCONDITION & -1 & GROUPMODE & & \\
\hline V2AE06a & $\mathrm{V} 2 \mathrm{~A}$ & & 2 & & 0.0395 & $\begin{array}{l}\text { (V2A) Have any of your biological mother, } \\
\text { sisters, half-sisters, or female first cousins } \\
\text { ever had: Delivery of a child more than } \\
3 \text { weeks before the expected due date }\end{array}$ \\
\hline V2AE06b & $\mathrm{V} 2 \mathrm{~A}$ & & 2 & & 0.0414 & $\begin{array}{l}\text { (V2A)' ' Delivery of a child weighing less } \\
\text { than } 5 \mathrm{lb} 8 \mathrm{oz} \text { (or } 2500 \text { grams) }\end{array}$ \\
\hline $\mathrm{V} 2 \mathrm{AE} 06 \mathrm{c}$ & $\mathrm{V} 2 \mathrm{~A}$ & & 2 & & 0.044 & $\begin{array}{l}(\mathrm{V} 2 \mathrm{~A})^{\prime}{ }^{\prime} ' \text { Spontaneous preterm delivery } \\
(<37 \text { weeks })\end{array}$ \\
\hline V2AE06d & $\mathrm{V} 2 \mathrm{~A}$ & & 2 & & 0.0639 & $\begin{array}{l}(\mathrm{V} 2 \mathrm{~A})^{\prime} \text { ' } \\
\text { membranes }\end{array}$ \\
\hline V2AE06e & $\mathrm{V} 2 \mathrm{~A}$ & & 2 & & 0.0542 & $\begin{array}{l}(\mathrm{V} 2 \mathrm{~A})^{\prime} \text { ' Preeclampsia, eclampsia, toxemia } \\
\text { or pregnancy induced hypertension }\end{array}$ \\
\hline V2AE06f & $\mathrm{V} 2 \mathrm{~A}$ & & 2 & & 0.0507 & $\begin{array}{l}\text { (V2A) ' ' Induction of labor due to low } \\
\text { amniotic fluid or poor fetal growth }\end{array}$ \\
\hline V2AE06g & $\mathrm{V} 2 \mathrm{~A}$ & & 2 & & 0.0268 & $(\mathrm{~V} 2 \mathrm{~A}))^{\prime}$ ' Stillbirth \\
\hline V2AE06h & $\mathrm{V} 2 \mathrm{~A}$ & & 2 & & 0.0227 & $\begin{array}{l}\text { (V2A) ' ' Delivery of an infant with } \\
\text { a birth defect }\end{array}$ \\
\hline V2AE06i & $\mathrm{V} 2 \mathrm{~A}$ & & 2 & & 0.0266 & $\begin{array}{l}\text { (V2A)' ' Other pregnancy complication, } \\
\text { specify }\end{array}$ \\
\hline $\begin{array}{l}\text { V2A_spontaneous_score, } \\
\text { V2A_indicated_score, } \\
\text { V2A_fetal_condition_score }\end{array}$ & $\mathrm{V} 2 \mathrm{~A}$ & GROUPCONDITION & -1 & GROUPMEAN & & \\
\hline V2AE07_1a & $\mathrm{V} 2 \mathrm{~A}$ & & 2 & & 0.6137 & $\begin{array}{l}\text { (V2A) Family members with pregnancy } \\
\text { complications - Family relation (1) }\end{array}$ \\
\hline V2AE07_1b1 & $\mathrm{V} 2 \mathrm{~A}$ & & 2 & & 0.6142 & $(\mathrm{~V} 2 \mathrm{~A}){ }^{\prime}$ ' Pregnancy complication $1(1)$ \\
\hline V2AE07_1b2 & $\mathrm{V} 2 \mathrm{~A}$ & & 2 & & 0.8259 & $(\mathrm{~V} 2 \mathrm{~A}){ }^{\prime}$ ' Pregnancy complication $2(1)$ \\
\hline V2AE07_1b3 & $\mathrm{V} 2 \mathrm{~A}$ & & 2 & & 0.9062 & $(\mathrm{~V} 2 \mathrm{~A}){ }^{\prime}$ ' Pregnancy complication $3(1)$ \\
\hline V2AE07_1b4 & $\mathrm{V} 2 \mathrm{~A}$ & & 2 & & 0.9629 & $($ V2A) ' ' Pregnancy complication 4 (1) \\
\hline V2AE07_1b5 & $\mathrm{V} 2 \mathrm{~A}$ & & 2 & & 0.9902 & $(\mathrm{~V} 2 \mathrm{~A}){ }^{\prime} '$ ' Pregnancy complication 5 (1) \\
\hline V2AE07_1c1 & $\mathrm{V} 2 \mathrm{~A}$ & & 2 & & 0.93 & $(\mathrm{~V} 2 \mathrm{~A}){ }^{\prime}{ }^{\prime}$ Pregnancy complication 6 , specify (1) \\
\hline V2AE07_1c2 & $\mathrm{V} 2 \mathrm{~A}$ & & 2 & & 0.9939 & $(\mathrm{~V} 2 \mathrm{~A}){ }^{\prime} \mid '$ Pregnancy complication 7 , specify (1) \\
\hline V2AE07_2a & $\mathrm{V} 2 \mathrm{~A}$ & & 2 & & 0.9261 & $(\mathrm{~V} 2 \mathrm{~A})$ ' 1 Family relation $(2)$ \\
\hline V2AE07_2b1 & $\mathrm{V} 2 \mathrm{~A}$ & & 2 & & 0.9269 & $(\mathrm{~V} 2 \mathrm{~A})$ ' ' Pregnancy complication $1(2)$ \\
\hline V2AE07_2b2 & $\mathrm{V} 2 \mathrm{~A}$ & & 2 & & 0.9833 & $(\mathrm{~V} 2 \mathrm{~A})$ ' ' Pregnancy complication $2(2)$ \\
\hline V2AE07_2b3 & $\mathrm{V} 2 \mathrm{~A}$ & & 2 & & 0.9925 & $(\mathrm{~V} 2 \mathrm{~A})$ ' ' Pregnancy complication $3(2)$ \\
\hline V2AE07_2b4 & $\mathrm{V} 2 \mathrm{~A}$ & & 2 & & 0.9973 & $(\mathrm{~V} 2 \mathrm{~A})$ ' ' Pregnancy complication $4(2)$ \\
\hline V2AE07_2b5 & $\mathrm{V} 2 \mathrm{~A}$ & & 2 & & 0.9993 & $(\mathrm{~V} 2 \mathrm{~A})$ ' ' Pregnancy complication $5(2)$ \\
\hline V2AE07_2c1 & $\mathrm{V} 2 \mathrm{~A}$ & & 2 & & 0.9873 & $(\mathrm{~V} 2 \mathrm{~A}){ }^{\prime}$ ' Pregnancy complication 6 , specify (2) \\
\hline V2AE07_2c2 & $\mathrm{V} 2 \mathrm{~A}$ & & 2 & & 0.9982 & 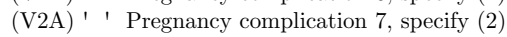 \\
\hline V2AE07_3a & $\mathrm{V} 2 \mathrm{~A}$ & & 2 & & 0.9849 & $(\mathrm{~V} 2 \mathrm{~A})$ ' ' Family relation (3) \\
\hline V2AE07_3b1 & $\mathrm{V} 2 \mathrm{~A}$ & & 2 & & 0.985 & $(\mathrm{~V} 2 \mathrm{~A}){ }^{\prime}$ ' Pregnancy complication $1(3)$ \\
\hline V2AE07_3b2 & $\mathrm{V} 2 \mathrm{~A}$ & & 2 & & 0.9985 & $(\mathrm{~V} 2 \mathrm{~A}){ }^{\prime}$ ' Pregnancy complication $2(3)$ \\
\hline V2AE07_3b3 & $\mathrm{V} 2 \mathrm{~A}$ & & 2 & & 0.9993 & $(\mathrm{~V} 2 \mathrm{~A})$ ' ' Pregnancy complication $3(3)$ \\
\hline V2AE07_3b4 & $\mathrm{V} 2 \mathrm{~A}$ & & 2 & & 0.9998 & $(\mathrm{~V} 2 \mathrm{~A})$ ' ' Pregnancy complication $4(3)$ \\
\hline V2AE07_3b5 & $\mathrm{V} 2 \mathrm{~A}$ & & 2 & & 1 & $(\mathrm{~V} 2 \mathrm{~A}){ }^{\prime}$ ' Pregnancy complication $5(3)$ \\
\hline V2AE07_3c1 & $\mathrm{V} 2 \mathrm{~A}$ & & 2 & & 0.9967 & $(\mathrm{~V} 2 \mathrm{~A}){ }^{\prime} '$ ' Pregnancy complication 6 , specify (3) \\
\hline V2AE07_3c2 & $\mathrm{V} 2 \mathrm{~A}$ & & 2 & & 0.9996 & $(\mathrm{~V} 2 \mathrm{~A}){ }^{\prime} \mid$ Pregnancy complication 7 , specify $(3)$ \\
\hline V2AE07_4a & $\mathrm{V} 2 \mathrm{~A}$ & & 2 & & 0.9964 & $(\mathrm{~V} 2 \mathrm{~A})$ ' ' Family relation (4) \\
\hline V2AE07_4b1 & $\mathrm{V} 2 \mathrm{~A}$ & & 2 & & 0.9964 & $(\mathrm{~V} 2 \mathrm{~A}){ }^{\prime}$, Pregnancy complication $1(4)$ \\
\hline V2AE07_4b2 & $\mathrm{V} 2 \mathrm{~A}$ & & 2 & & 0.9999 & $(\mathrm{~V} 2 \mathrm{~A})$ ' ' Pregnancy complication $2(4)$ \\
\hline V2AE07_4b3 & $\mathrm{V} 2 \mathrm{~A}$ & & 2 & & 1 & $(\mathrm{~V} 2 \mathrm{~A})$ ' ' Pregnancy complication $3(4)$ \\
\hline V2AE07_4b4 & $\mathrm{V} 2 \mathrm{~A}$ & & 2 & & 1 & $(\mathrm{~V} 2 \mathrm{~A})$ ' 1 Pregnancy complication $4(4)$ \\
\hline V2AE07_4b5 & $\mathrm{V} 2 \mathrm{~A}$ & & 2 & & 1 & $(\mathrm{~V} 2 \mathrm{~A})$ ' ' Pregnancy complication 5 (4) \\
\hline V2AE07_4c1 & $\mathrm{V} 2 \mathrm{~A}$ & & 2 & & 0.9995 & $(\mathrm{~V} 2 \mathrm{~A}){ }^{\prime} \mid$ Pregnancy complication 6, specify $(4)$ \\
\hline V2AE07_4c2 & $\mathrm{V} 2 \mathrm{~A}$ & & 2 & & 1 & $(\mathrm{~V} 2 \mathrm{~A}){ }^{\prime}{ }^{\prime}$ Pregnancy complication 7 , specify (4) \\
\hline V2AE07_5a & $\mathrm{V} 2 \mathrm{~A}$ & & 2 & & 0.9992 & $(\mathrm{~V} 2 \mathrm{~A}), \mid$ Family relation $(5)$ \\
\hline V2AE07_5b1 & $\mathrm{V} 2 \mathrm{~A}$ & & 2 & & 0.9992 & $(\mathrm{~V} 2 \mathrm{~A}){ }^{\prime} \mid$ Pregnancy complication $1(5)$ \\
\hline V2AE07_5b2 & $\mathrm{V} 2 \mathrm{~A}$ & & 2 & & 1 & $(\mathrm{~V} 2 \mathrm{~A}){ }^{\prime}$ ' Pregnancy complication $2(5)$ \\
\hline V2AE07_5b3 & $\mathrm{V} 2 \mathrm{~A}$ & & 2 & & 1 & $(\mathrm{~V} 2 \mathrm{~A}){ }^{\prime}$ ' Pregnancy complication $3(5)$ \\
\hline V2AE07_5b4 & $\mathrm{V} 2 \mathrm{~A}$ & & 2 & & 1 & $(\mathrm{~V} 2 \mathrm{~A}){ }^{\prime}$ ' Pregnancy complication $4(5)$ \\
\hline V2AE07_5b5 & $\mathrm{V} 2 \mathrm{~A}$ & & 2 & & 1 & $(\mathrm{~V} 2 \mathrm{~A}){ }^{\prime}{ }^{\prime}$ Pregnancy complication $5(5)$ \\
\hline V2AE07_5c1 & $\mathrm{V} 2 \mathrm{~A}$ & & 2 & & 1 & $(\mathrm{~V} 2 \mathrm{~A}){ }^{\prime}$ ' Pregnancy complication 6 , specify (5) \\
\hline V2AE07_5c2 & $\mathrm{V} 2 \mathrm{~A}$ & & 2 & & 0.9999 & $(\mathrm{~V} 2 \mathrm{~A}){ }^{\prime}{ }^{\prime}$ Pregnancy complication 7 , specify (5) \\
\hline
\end{tabular}




\subsection{Toxicology}

The toxicology filtering relates to questions and chart abstractions regarding any kind of drug use, prescription or non-prescription, by the patient. This includes questions regarding alcohol, tobacco usage, second-hand smoke, smoking cessation, illegal drugs, all prescription medications noted, vitamins, vaccines, and whether medication was being taken for a particular condition. The information used comes from both patient interviews and ancillary files, which corrected the medication information through consensus and chart review.

Total \# Features: 806

Layer 1 \# Features: 63

Layer 2 \# Features: 63

Relevant Files: drugs_in_pregnancy (ancillary), VXX, V1A, V2A, V3A, V4A

Dropped Features: General questions on if a class of drug (non-prescribed) was used were kept in L1. Some detail was saved for L2, such as illegal drug use breakdown. Prescription drugs were organized back into drug categories originally used by the nuMoM2b team in order to reduce dimensionality (see form VXX Section C), perinatal vitamins were separated from the vitamins group due to feature compiled feature Vitamin_Multi_Perinatal_Folate, covering that information as well. Metadata features were used to organize and preprocess data, and then dropped from modeling. "Medication taken for condition" features in VXX are dropped as prescribed drugs (as mentioned earlier) and "condition noted" features from VXX in medical history filtering cover said information.

Table 5: Toxicology Filtering

\begin{tabular}{|c|c|c|c|c|c|c|}
\hline NAME & FILE & RULE & TEMPORAL & IMPUTE & MISSING & DESCRIPTION \\
\hline V1AG01 & V1A & & 1 & 999 & 0.0007 & (V1A) Have you ever drunk alcohol? \\
\hline V1AG04 & $\mathrm{V} 1 \mathrm{~A}$ & & 1 & 999 & 0.0009 & $\begin{array}{l}\text { (V1A) Have you ever used any tobacco products including } \\
\text { cigarettes and smokeless tobacco? }\end{array}$ \\
\hline V1AG05 & V1A & & 1 & 999 & 0.5825 & $\begin{array}{l}\text { (V1A) Did you smoke any tobacco products in the three } \\
\text { months prior to this pregnancy? }\end{array}$ \\
\hline V1AG07 & $\mathrm{V} 1 \mathrm{~A}$ & & 1 & 999 & 0.584 & (V1A) Did you smoke any tobacco products in the last month? \\
\hline V1AG11 & V1A & & 1 & 999 & 0.0013 & $\begin{array}{l}\text { (V1A) Have you ever used illegal drugs or drugs not } \\
\text { prescribed for you? }\end{array}$ \\
\hline V2AH02 & $\mathrm{V} 2 \mathrm{~A}$ & & 2 & 999 & 0.0007 & (V2A) Did you smoke any tobacco products in the last month? \\
\hline V2AH06 & $\mathrm{V} 2 \mathrm{~A}$ & & 2 & 999 & 0.0008 & $\begin{array}{l}\text { (V2A) Have you used illegal drugs or drugs not prescribed } \\
\text { for you in the last month? }\end{array}$ \\
\hline V3AF02 & $\mathrm{V} 3 \mathrm{~A}$ & & 3 & 999 & 0.0001 & (V3A) Did you smoke any tobacco products in the last month? \\
\hline V3AF06 & $\mathrm{V} 3 \mathrm{~A}$ & & 3 & 999 & 0.0005 & $\begin{array}{l}\text { (V3A) Have you used illegal drugs or drugs not prescribed } \\
\text { for you in the last month? }\end{array}$ \\
\hline V4AF02 & $\mathrm{V} 4 \mathrm{~A}$ & & 4 & 999 & 0.0011 & $\begin{array}{l}\text { (V4A) Did you smoke any tobacco products in the month } \\
\text { before your delivery? }\end{array}$ \\
\hline V4AF06 & $\mathrm{V} 4 \mathrm{~A}$ & & 4 & 999 & 0.001 & $\begin{array}{l}\text { (V4A) Have you used illegal drugs or drugs not prescribed } \\
\text { for you in the month before delivery? }\end{array}$ \\
\hline DrugName & $\begin{array}{l}\text { drugs_in_ } \\
\text { pregnancy } \\
\text { (ancillary) }\end{array}$ & & $\begin{array}{l}\text { VXXC01g, } \\
\text { VXXC01h }\end{array}$ & $\mathrm{N} / \mathrm{A}$ & 0 & Drug Name corrected from VXXC01b value provided \\
\hline DrugCode & $\begin{array}{l}\text { drugs_in_- } \\
\text { pregnancy } \\
\text { (ancillary) }\end{array}$ & & $\begin{array}{l}\text { VXXC01g, } \\
\text { VXXC01h }\end{array}$ & $\mathrm{N} / \mathrm{A}$ & 0 & Drug Code corrected from VXXC01c value provided \\
\hline ReasonCode & $\begin{array}{l}\text { drugs_in_ } \\
\text { pregnancy } \\
\text { (ancillary) }\end{array}$ & & $\begin{array}{l}\text { VXXC01g, } \\
\text { VXXC01h }\end{array}$ & $\mathrm{N} / \mathrm{A}$ & 0 & Reason Code corrected from VXXC01e value provided \\
\hline VXXC01g & $\begin{array}{l}\text { drugs_in } \\
\text { pregnancy } \\
\text { (ancillary) }\end{array}$ & & Itself & $\mathrm{N} / \mathrm{A}$ & 0.0251 & (VXX) Medications and vaccinations - Start timing \\
\hline VXXC01h & $\begin{array}{l}\text { drugs_in_- } \\
\text { pregnancy } \\
\text { (ancillary) }\end{array}$ & & Itself & $\mathrm{N} / \mathrm{A}$ & 0.5536 & (VXX) Medications and vaccinations - Stopped timing \\
\hline V1AG05a & $\mathrm{V} 1 \mathrm{~A}$ & & 0 & 0 & 0.8234 & $\begin{array}{l}\text { (V1A) How many cigarettes did you smoke per day in the } \\
\text { three months prior to this pregnancy? - \# per day, }\end{array}$ \\
\hline V1AG07a & V1A & & 1 & 0 & 0.9413 & $\begin{array}{l}\text { (V1A) How many cigarettes did you smoke per day in the } \\
\text { last month? - \# per day, }\end{array}$ \\
\hline V2AH02a & $\mathrm{V} 2 \mathrm{~A}$ & & 2 & 0 & 0.9471 & $\begin{array}{l}\text { (V2A) How many cigarettes did you smoke per day? } \\
\text { - \# per day }\end{array}$ \\
\hline V3AF02a & V3A & & 3 & 0 & 0.9532 & $\begin{array}{l}\text { (V3A) How many cigarettes did you smoke per day? } \\
\text { - \# per day }\end{array}$ \\
\hline V4AF02a & $\mathrm{V} 4 \mathrm{~A}$ & & 4 & 0 & 0.9618 & $\begin{array}{l}\text { (V4A) In the month before delivery - How many cigarettes } \\
\text { did you smoke per day? \# per day }\end{array}$ \\
\hline V1AG10 & V1A & & 1 & 0 & 0.5834 & $\begin{array}{l}\text { (V1A) In the last month, did you use smokeless tobacco } \\
\text { (chew or snuff)?, }\end{array}$ \\
\hline
\end{tabular}




\begin{tabular}{|c|c|c|c|c|c|c|}
\hline NAME & FILE & RULE & TEMPORAL & IMPUTE & MISSING & DESCRIPTION \\
\hline V2AH05 & $\mathrm{V} 2 \mathrm{~A}$ & & 2 & 0 & 0.0045 & $\begin{array}{l}\text { (V2A) In the last month, did you use smokeless tobacco } \\
\text { (chew or snuff)? }\end{array}$ \\
\hline V3AF05 & $\mathrm{V} 3 \mathrm{~A}$ & & 3 & 0 & 0.004 & $\begin{array}{l}\text { (V3A) In the last month, did you use smokeless tobacco } \\
\text { (chew or snuff)? }\end{array}$ \\
\hline V4AF05 & $\mathrm{V} 4 \mathrm{~A}$ & & 4 & 0 & 0.0045 & $\begin{array}{l}\text { (V4A) In the month before your delivery - Did you use } \\
\text { smokeless tobacco (chew or snuff)? }\end{array}$ \\
\hline drug_category & $\begin{array}{l}\text { drugs_in_- } \\
\text { pregnancy } \\
\text { (ancillary) }\end{array}$ & $\begin{array}{l}\text { drug_cat_ } \\
\text { creation }\end{array}$ & $\begin{array}{l}\text { VXXC01g, } \\
\text { VXXC01h }\end{array}$ & $\mathrm{N} / \mathrm{A}$ & 0 & $\begin{array}{l}\text { Compilation of DrugCode's into the respective medication } \\
\text { categories as specified in VXX Section C. }\end{array}$ \\
\hline DrugCode & $\begin{array}{l}\text { drugs_in_- } \\
\text { pregnancy } \\
\text { (ancillary) }\end{array}$ & & $\begin{array}{l}\text { VXXC01g, } \\
\text { VXXC01h }\end{array}$ & & 0 & Drug Code corrected from VXXC01c value provided \\
\hline VXXC01k & $\begin{array}{l}\text { drugs_in_- } \\
\text { pregnancy } \\
\text { (ancillary) }\end{array}$ & & $\mathrm{N} / \mathrm{A}$ & & 0 & $\begin{array}{l}\text { (VXX) Medications and vaccinations - Final assessment: } \\
\text { Took medication/vaccine }\end{array}$ \\
\hline Alc_Usage_V0 & & AlcSum & 0 & 999 & & \\
\hline V1AG02a & V1A & & 0 & & 0.3559 & $\begin{array}{l}\text { (V1A) How many days per week did you drink in the } \\
\text { three months prior to this pregnancy? - days/week }\end{array}$ \\
\hline V1AG02b & $\mathrm{V} 1 \mathrm{~A}$ & & 0 & & 0.3558 & $\begin{array}{l}\text { (V1A) How many drinks did you drink per drinking } \\
\text { day in the three months prior to this pregnancy? - drinks }\end{array}$ \\
\hline Alc_Usage_V1 & & AlcSum & 1 & 999 & & \\
\hline V1AG03a & V1A & & 1 & & 0.9621 & $\begin{array}{l}\text { (V1A) How many days per week did you drink in the } \\
\text { last month? - days/week }\end{array}$ \\
\hline V1AG03b & $\mathrm{V} 1 \mathrm{~A}$ & & 1 & & 0.9621 & $\begin{array}{l}\text { (V1A) How many drinks did you drink per drinking } \\
\text { day in the last month? - drinks }\end{array}$ \\
\hline Quit_Smoke_V1 & & QuitSmoke & 1 & & & \\
\hline V1AG08 & $\mathrm{V} 1 \mathrm{~A}$ & & 1 & 2 & 0.5833 & $\begin{array}{l}\text { (V1A) In the last month, did you use nicotine gum, a } \\
\text { nicotine patch, a nicotine spray or a nicotine inhaler? } \\
\text { (V1A) In the last month, did you take a pill like Zyban }\end{array}$ \\
\hline V1AG09 & V1A & & 1 & 2 & 0.5833 & $\begin{array}{l}\text { (also known as Wellbutrin or Bupropion) to help you } \\
\text { quit smoking? }\end{array}$ \\
\hline SecH_Smoke_V1 & & SecondHand & 1 & & & \\
\hline V1AG07b & $\mathrm{V} 1 \mathrm{~A}$ & & 1 & 2 & 0.4472 & $\begin{array}{l}\text { (V1A) In the last month, on average how many hours } \\
\text { per week were you exposed to cigarette smoke because } \\
\text { of smoking... }\end{array}$ \\
\hline V1AG07c & $\mathrm{V} 1 \mathrm{~A}$ & & 1 & 2 & 0.4463 & $\begin{array}{l}\text { (V1A) In the last month, how many people (excluding } \\
\text { yourself) smoked cigarettes inside the home... }\end{array}$ \\
\hline Drug_Usage_V1 & & DrugScale & 1 & 999 & & \\
\hline V1AG12a & V1A & & 1 & & 0.6612 & (V1A) Every used any of these drugs - Marijuana (THC) \\
\hline V1AG12b & $\mathrm{V} 1 \mathrm{~A}$ & & 1 & & 0.6622 & (V1A) Every used any of these drugs - Cocaine \\
\hline V1AG12c & V1A & & 1 & & 0.6636 & \\
\hline V1AG12d & V1A & & 1 & & 0.6627 & (V1A) Every used any of these drugs - Heroin \\
\hline V1AG12d1 & V1A & & 1 & & 0.9899 & (V1A) Every used any of these drugs - Heroin, Snorted \\
\hline V1AG12d2 & V1A & & 1 & & 0.99 & (V1A) Every used any of these drugs - Heroin, Injected \\
\hline V1AG12d3 & V1A & & 1 & & 0.9907 & (V1A) Every used any of these drugs - Heroin, Smoked \\
\hline V1AG12d4 & $\mathrm{V} 1 \mathrm{~A}$ & & 1 & & 0.9906 & (V1A) Every used any of these drugs - Heroin, Other \\
\hline $\begin{array}{l}\text { V1AG12d4 } \\
\text { _SP }\end{array}$ & V1A & & 1 & & 0.9999 & (V1A) Every used any of these drugs - Heroin, Other, specify \\
\hline V1AG12e & $\mathrm{V} 1 \mathrm{~A}$ & & 1 & & 0.6692 & (V1A) Every used any of these drugs - Methadone \\
\hline V1AG12f & $\mathrm{V} 1 \mathrm{~A}$ & & 1 & & 0.666 & $\begin{array}{l}\text { (V1A) Every used any of these drugs - Amphetamines } \\
\text { (speed) not prescribed for you }\end{array}$ \\
\hline V1AG12g & V1A & & 1 & & 0.6665 & $\begin{array}{l}\text { (V1A) Every used any of these drugs - Inhalants not } \\
\text { prescribed for you }\end{array}$ \\
\hline V1AG12h & $\mathrm{V} 1 \mathrm{~A}$ & & 1 & & 0.6658 & (V1A) Every used any of these drugs - Hallucinogens \\
\hline V1AG12i & V1A & & 1 & & 0.6702 & (V1A) Every used any of these drugs - Other \\
\hline V1AG12i_SP & V1A & & 1 & & 0.9765 & (V1A) Every used any of these drugs - Other, specify \\
\hline Alc_Usage_V2 & & AlcSum & 2 & 999 & & \\
\hline V2AH01a & V2A & & 2 & & 0.9439 & (V2A) How many days per week did you drink? - days/week \\
\hline V2AH01b & $\mathrm{V} 2 \mathrm{~A}$ & & 2 & & 0.9443 & $\begin{array}{l}\text { (V2A) How many drinks did you drink per drinking day? } \\
\text { - drinks }\end{array}$ \\
\hline Quit_Smoke_V2 & & QuitSmoke & 2 & & & \\
\hline V2AH03 & $\mathrm{V} 2 \mathrm{~A}$ & & 2 & 2 & 0.0046 & $\begin{array}{l}\text { (V2A) In the last month, did you use nicotine gum, a } \\
\text { nicotine patch, a nicotine spray or a nicotine inhaler? } \\
\text { (V2A) In the last month, did you take a pill like Zyban }\end{array}$ \\
\hline V2AH04 & $\mathrm{V} 2 \mathrm{~A}$ & & 2 & 2 & 0.0044 & $\begin{array}{l}\text { (also known as Wellbutrin or Bupropion) to help you } \\
\text { quit smoking? }\end{array}$ \\
\hline
\end{tabular}


medRxiv preprint doi: https://doi.org/10.1101/2021.08.24.21262142; this version posted August 26, 2021. The copyright holder for this preprint (which was not certified by peer review) is the author/funder, who has granted medRxiv a license to display the preprint in perpetuity.

\section{It is made available under a CC-BY-NC-ND 4.0 International license .}

\begin{tabular}{|c|c|c|c|c|c|c|}
\hline NAME & FILE & RULE & TEMPORAL & IMPUTE & MISSING & DESCRIPTION \\
\hline SecH_Smoke_V2 & & SecondHand & 2 & & & \\
\hline V2AH02b & $\mathrm{V} 2 \mathrm{~A}$ & & 2 & 2 & 0.0045 & $\begin{array}{l}\text { (V2A) In the last month, on average how many hours } \\
\text { per week were you exposed to cigarette smoke because } \\
\text { of smoking... }\end{array}$ \\
\hline $\mathrm{V} 2 \mathrm{AH} 02 \mathrm{c}$ & $\mathrm{V} 2 \mathrm{~A}$ & & 2 & 2 & 0.0008 & $\begin{array}{l}\text { (V2A) In the last month, how many people (excluding } \\
\text { yourself) smoked cigarettes inside the home... }\end{array}$ \\
\hline Drug_Usage_V2 & & DrugScale & 2 & 999 & & \\
\hline V2AH07a & $\mathrm{V} 2 \mathrm{~A}$ & & 2 & & 0.9888 & (V2A) Drug use in the past month - Marijuana (THC) \\
\hline V2AH07b & $\mathrm{V} 2 \mathrm{~A}$ & & 2 & & 0.989 & (V2A) Drug use in the past month - Cocaine \\
\hline V2AH07c & $\mathrm{V} 2 \mathrm{~A}$ & & 2 & & 0.989 & $\begin{array}{l}\text { (V2A) Drug use in the past month - Prescription } \\
\text { narcotics that were not prescribed for you }\end{array}$ \\
\hline V2AH07d & $\mathrm{V} 2 \mathrm{~A}$ & & 2 & & 0.989 & (V2A) Drug use in the past month - Heroin \\
\hline V2AH07d1 & $\mathrm{V} 2 \mathrm{~A}$ & & 2 & & 0.9998 & (V2A) Drug use in the past month - Heroin, Snorted \\
\hline V2AH07d2 & $\mathrm{V} 2 \mathrm{~A}$ & & 2 & & 0.9998 & (V2A) Drug use in the past month - Heroin, Injected \\
\hline V2AH07d3 & $\mathrm{V} 2 \mathrm{~A}$ & & 2 & & 0.9998 & (V2A) Drug use in the past month - Heroin, Smoked \\
\hline V2AH07d4 & $\mathrm{V} 2 \mathrm{~A}$ & & 2 & & 0.9998 & (V2A) Drug use in the past month - Heroin, Other \\
\hline $\begin{array}{l}\text { V } 2 \mathrm{AH} 07 \mathrm{~d} 4 \\
\text { SPP }\end{array}$ & $\mathrm{V} 2 \mathrm{~A}$ & & 2 & & 1 & (V2A) Drug use in the past month - Heroin, Other, specify \\
\hline V2AH07e & $\mathrm{V} 2 \mathrm{~A}$ & & 2 & & 0.9891 & (V2A) Drug use in the past month - Methadone \\
\hline V2AH07f & $\mathrm{V} 2 \mathrm{~A}$ & & 2 & & 0.9891 & $\begin{array}{l}\text { (V2A) Drug use in the past month - Amphetamines } \\
\text { (speed) not prescribed for you }\end{array}$ \\
\hline V2AH07g & $\mathrm{V} 2 \mathrm{~A}$ & & 2 & & 0.9891 & $\begin{array}{l}\text { (V2A) Drug use in the past month - Inhalants not } \\
\text { prescribed for you }\end{array}$ \\
\hline V2AH07h & $\mathrm{V} 2 \mathrm{~A}$ & & 2 & & 0.9891 & (V2A) Drug use in the past month - Hallucinogens \\
\hline V2AH07i & $\mathrm{V} 2 \mathrm{~A}$ & & 2 & & 0.9891 & (V2A) Drug use in the past month - Other \\
\hline V2AH07i_SP & $\mathrm{V} 2 \mathrm{~A}$ & & 2 & & 0.9998 & (V2A) Drug use in the past month - Other, specify \\
\hline Alc_Usage_V3 & & AlcSum & 3 & 999 & & \\
\hline V3AF01a & V3A & & 3 & & 0.9303 & (V3A) How many days per week did you drink? - days/week \\
\hline V3AF01b & V3A & & 3 & & 0.9308 & $\begin{array}{l}\text { (V3A) How many drinks did you drink per drinking day? } \\
\text { - drinks }\end{array}$ \\
\hline Quit_Smoke_V3 & & QuitSmoke & 3 & & & \\
\hline V3AF04 & $\mathrm{V} 3 \mathrm{~A}$ & & 3 & 2 & 0.0041 & $\begin{array}{l}\text { (V3A) In the last month, did you use nicotine gum, a } \\
\text { nicotine patch, a nicotine spray or a nicotine inhaler? } \\
\text { (V3A) In the last month, did you take a pill like Zyban } \\
\text { (also known as Wellbutrin or Bupropion) to help } \\
\text { you quit smoking? }\end{array}$ \\
\hline SecH_Smoke_V3 & & SecondHand & 3 & & & \\
\hline V3AF02b & V3A & & 3 & 2 & 0.3266 & $\begin{array}{l}\text { (V3A) In the last month, on average how many hours } \\
\text { per week were you exposed to cigarette smoke because } \\
\text { of smoking... }\end{array}$ \\
\hline V3AF02c & V3A & & 3 & 2 & 0.3262 & $\begin{array}{l}\text { (V3A) In the last month, how many people (excluding } \\
\text { yourself) smoked cigarettes inside the home... }\end{array}$ \\
\hline Drug_Usage_V3 & & DrugScale & 3 & 999 & & \\
\hline V3AF07a & V3A & & 3 & & 0.9932 & (V3A) Drug use in the past month - Marijuana (THC) \\
\hline V3AF07b & $\mathrm{V} 3 \mathrm{~A}$ & & 3 & & 0.9932 & (V3A) Drug use in the past month - Cocaine \\
\hline V3AF07c & $\mathrm{V} 3 \mathrm{~A}$ & & 3 & & 0.9932 & $\begin{array}{l}\text { (V3A) Drug use in the past month - Prescription } \\
\text { narcotics that were not prescribed for you }\end{array}$ \\
\hline V3AF07d & $\mathrm{V} 3 \mathrm{~A}$ & & 3 & & 0.9932 & (V3A) Drug use in the past month - Heroin \\
\hline V3AF07d1 & $\mathrm{V} 3 \mathrm{~A}$ & & 3 & & 1 & (V3A) Drug use in the past month - Heroin, Snorted \\
\hline V3AF07d2 & $\mathrm{V} 3 \mathrm{~A}$ & & 3 & & 1 & (V3A) Drug use in the past month - Heroin, Injected \\
\hline V3AF07d3 & $\mathrm{V} 3 \mathrm{~A}$ & & 3 & & 1 & (V3A) Drug use in the past month - Heroin, Smoked \\
\hline V3AF07d4 & $\mathrm{V} 3 \mathrm{~A}$ & & 3 & & 1 & (V3A) Drug use in the past month - Heroin, Other \\
\hline $\begin{array}{l}\text { V3AF07d4 } \\
\text { _SP }\end{array}$ & $\mathrm{V} 3 \mathrm{~A}$ & & 3 & & 1 & (V3A) Drug use in the past month - Heroin, Other, specify \\
\hline V3AF07e & $\mathrm{V} 3 \mathrm{~A}$ & & 3 & & 0.9932 & (V3A) Drug use in the past month - Methadone \\
\hline V3AF07f & $\mathrm{V} 3 \mathrm{~A}$ & & 3 & & 0.9932 & $\begin{array}{l}\text { (V3A) Drug use in the past month - Amphetamines } \\
\text { (speed) not prescribed for you }\end{array}$ \\
\hline V3AF07g & V3A & & 3 & & 0.9932 & $\begin{array}{l}\text { (V3A) Drug use in the past month - Inhalants not } \\
\text { prescribed for you }\end{array}$ \\
\hline V3AF07h & V3A & & 3 & & 0.9932 & (V3A) Drug use in the past month - Hallucinogens \\
\hline V3AF07i & $\mathrm{V} 3 \mathrm{~A}$ & & 3 & & 0.9932 & (V3A) Drug use in the past month - Other \\
\hline V3AF07i_SP & V3A & & 3 & & 0.9998 & (V3A) Drug use in the past month - Other, specify \\
\hline Alc_Usage_V4 & & AlcSum & 4 & 999 & & \\
\hline V4AF01a & $\mathrm{V} 4 \mathrm{~A}$ & & 4 & & 0.9399 & $\begin{array}{l}\text { (V4A) In the month before delivery - How many } \\
\text { days per week did you drink? days/week }\end{array}$ \\
\hline V4AF01b & $\mathrm{V} 4 \mathrm{~A}$ & & 4 & & 0.94 & $\begin{array}{l}\text { (V4A) In the month before delivery - How many } \\
\text { drinks did you drink per drinking day? }\end{array}$ \\
\hline
\end{tabular}


medRxiv preprint doi: https://doi.org/10.1101/2021.08.24.21262142; this version posted August 26, 2021. The copyright holder for this preprint (which was not certified by peer review) is the author/funder, who has granted medRxiv a license to display the preprint in perpetuity.

\section{It is made available under a CC-BY-NC-ND 4.0 International license .}

\begin{tabular}{|c|c|c|c|c|c|c|}
\hline NAME & FILE & RULE & TEMPORAL & IMPUTE & MISSING & DESCRIPTION \\
\hline Quit_Smoke_V4 & & QuitSmoke & 4 & & & \multirow{3}{*}{$\begin{array}{l}\text { (V4A) In the month before your delivery - Did you } \\
\text { use nicotine gum, a nicotine patch, a nicotine } \\
\text { spray or a nicotine inhaler? } \\
\text { (V4A) In the month before your delivery - Did you } \\
\text { take a pill like Zyban (also known as Wellbutrin } \\
\text { or Bupropion) to help you quit smoking? }\end{array}$} \\
\hline V4AF03 & $\mathrm{V} 4 \mathrm{~A}$ & & 4 & 2 & 0.0045 & \\
\hline V4AF04 & $\mathrm{V} 4 \mathrm{~A}$ & & 4 & 2 & 0.0045 & \\
\hline SecH_Smoke_V4 & & SecondHand & 4 & & & \multirow{3}{*}{$\begin{array}{l}\text { (V4A) In the last month, on average how many } \\
\text { hours per week were you exposed to cigarette } \\
\text { smoke because of smoking... } \\
\text { (V4A) In the last month, how many people } \\
\text { (excluding yourself) smoked cigarettes inside } \\
\text { the home... }\end{array}$} \\
\hline $\mathrm{V} 4 \mathrm{AF} 02 \mathrm{~b}$ & $\mathrm{~V} 4 \mathrm{~A}$ & & 4 & 2 & 0.2594 & \\
\hline $\mathrm{V} 4 \mathrm{AF} 02 \mathrm{c}$ & $\mathrm{V} 4 \mathrm{~A}$ & & 4 & 2 & 0.2591 & \\
\hline Drug_Usage_V4 & & DrugScale & 4 & 999 & & \\
\hline V4AF07a & V4A & & 4 & & 0.9964 & \multirow{15}{*}{$\begin{array}{l}\text { (V4A) Drug use in the last month - Marijuana (THC) } \\
\text { (V4A) Drug use in the last month - Cocaine } \\
\text { (V4A) Drug use in the last month - Prescription } \\
\text { narcotics that were not prescribed for you } \\
\text { (V4A) Drug use in the last month - Heroin } \\
\text { (V4A) Drug use in the last month - Heroin, Snorted } \\
\text { (V4A) Drug use in the last month - Heroin, Injected } \\
\text { (V4A) Drug use in the last month - Heroin, Smoked } \\
\text { (V4A) Drug use in the last month - Heroin, Other } \\
\text { (V4A) Drug use in the last month - Heroin, Other, specify } \\
\text { (V4A) Drug use in the last month - Methadone } \\
\text { (V4A) Drug use in the last month - Amphetamines } \\
\text { (speed) not prescribed for you } \\
\text { (V4A) Drug use in the last month - Inhalants not } \\
\text { prescribed for you } \\
\text { (V4A) Drug use in the last month - Hallucinogens } \\
\text { (V4A) Drug use in the last month - Other } \\
\text { (V4A) Drug use in the last month - Other, specify }\end{array}$} \\
\hline V4AF07b & $\mathrm{V} 4 \mathrm{~A}$ & & 4 & & 0.9964 & \\
\hline $\mathrm{V} 4 \mathrm{AF} 07 \mathrm{c}$ & $\mathrm{V} 4 \mathrm{~A}$ & & 4 & & 0.9964 & \\
\hline V4AF07d & $\mathrm{V} 4 \mathrm{~A}$ & & 4 & & 0.9964 & \\
\hline V4AF07d1 & $\mathrm{V} 4 \mathrm{~A}$ & & 4 & & 0.9996 & \\
\hline V4AF07d2 & V4A & & 4 & & 0.9996 & \\
\hline V4AF07d3 & V4A & & 4 & & 0.9996 & \\
\hline V4AF07d4 & $\mathrm{V} 4 \mathrm{~A}$ & & 4 & & 0.9996 & \\
\hline $\begin{array}{l}\text { V4AF07d4 } \\
\text { _SP }\end{array}$ & $\mathrm{V} 4 \mathrm{~A}$ & & 4 & & 1 & \\
\hline V4AF07e & $\mathrm{V} 4 \mathrm{~A}$ & & 4 & & 0.9964 & \\
\hline V4AF07f & $\mathrm{V} 4 \mathrm{~A}$ & & 4 & & 0.9964 & \\
\hline V4AF07g & V4A & & 4 & & 0.9964 & \\
\hline V4AF07h & $\mathrm{V} 4 \mathrm{~A}$ & & 4 & & 0.9964 & \\
\hline V4AF07i & $\mathrm{V} 4 \mathrm{~A}$ & & 4 & & 0.9964 & \\
\hline V4AF07i_SP & $\mathrm{V} 4 \mathrm{~A}$ & & 4 & & 0.9997 & \\
\hline $\begin{array}{l}\text { Vitamin_Multi_ } \\
\text { Perinatal_Folate }\end{array}$ & & WeekSum & $\mathrm{N} / \mathrm{A}$ & Mean & & \\
\hline VXXC02a & vXX & & $\mathrm{N} / \mathrm{A}$ & & 0.7405 & \multirow{3}{*}{$\begin{array}{l}\text { (VXX) How long have you been taking [perinatal } \\
\text { vitamins/other multivitamins/ folate supplements]? - wks } \\
\text { (VXX) How long have you been taking [perinatal } \\
\text { vitamins/other multivitamins/ folate supplements]? - months } \\
\text { (VXX) How long have you been taking [perinatal } \\
\text { vitamins/other multivitamins/ folate supplements]? - years }\end{array}$} \\
\hline $\mathrm{VXXC02b}$ & vXX & & $\mathrm{N} / \mathrm{A}$ & & 0.499 & \\
\hline $\mathrm{VXXC02c}$ & vXX & & $\mathrm{N} / \mathrm{A}$ & & 0.8739 & \\
\hline
\end{tabular}

Toxicology Filtering 
medRxiv preprint doi: https://doi.org/10.1101/2021.08.24.21262142; this version posted August 26, 2021. The copyright holder for this preprint (which was not certified by peer review) is the author/funder, who has granted medRxiv a license to display the preprint in perpetuity.

\section{It is made available under a CC-BY-NC-ND 4.0 International license .}

\subsection{Psychological}

The psychological filtering compiled all of the features relating to psychological health and wellbeing, including previous treatment for mental health conditions in addition to surveys about factors related to depression, stress, resiliency and social support at the 3 visits.

Total \# Features: 172

Layer 1 \# Features: 8

Layer 2 \# Features: 8

Relevant Files: CMA, V1A, V2A, V1C, V1E, V1G, V1H, V2I, V3A, V3C, V3E, V3J

Dropped Features: We chose to discard features related to prenatal and postpartum treatment for mental health conditions, in the case that some conditions were not diagnosed, to focus on the current state of mind throughout the pregnancy as measured by the surveys.

Table 6: Psychological Filtering

\begin{tabular}{|c|c|c|c|c|c|c|}
\hline NAME & FILE & RULE & TEMPORAL & IMPUTE & MISSING & DESCRIPTION \\
\hline V1EA01 & V1E & & 1 & ONEHOT & 0.0887 & $\begin{array}{l}\text { (V1E) Are you feeling bothered, upset } \\
\text { or worried at this point in your } \\
\text { pregnancy? }\end{array}$ \\
\hline V3EA01 & V3E & & 3 & ONEHOT & 0.0826 & $\begin{array}{l}\text { (V3E) Are you feeling bothered, upset } \\
\text { or worried at this point in your } \\
\text { pregnancy? }\end{array}$ \\
\hline V1A_STRESS_SUMMARY & V1A & ADD & 1 & MEAN & & \\
\hline V1AH01 & $\mathrm{V} 1 \mathrm{~A}$ & & 1 & & 0.0039 & $\begin{array}{l}\text { (V1A) In the last month, how often have } \\
\text { you been upset because of something } \\
\text { that happened unexpectedly? }\end{array}$ \\
\hline V1AH02 & $\mathrm{V} 1 \mathrm{~A}$ & & 1 & & 0.004 & $\begin{array}{l}\text { (V1A) In the last month, how often have } \\
\text { you felt that you were unable to control } \\
\text { the important things in your life? }\end{array}$ \\
\hline V1AH03 & $\mathrm{V} 1 \mathrm{~A}$ & & 1 & & 0.0043 & $\begin{array}{l}\text { (V1A) In the last month, how often have } \\
\text { you felt nervous and 'stressed'? } \\
\text { (V1A) In the last month, how often have }\end{array}$ \\
\hline V1AH04 & $\mathrm{V} 1 \mathrm{~A}$ & & 1 & & 0.0041 & $\begin{array}{l}\text { you felt confident about your ability to } \\
\text { handle your personal problems? }\end{array}$ \\
\hline V1AH05 & $\mathrm{V} 1 \mathrm{~A}$ & & 1 & & 0.0045 & $\begin{array}{l}\text { (V1A) In the last month, how often have } \\
\text { you felt that things were going your way? } \\
\text { (V1A) In the last month, how often have }\end{array}$ \\
\hline V1AH06 & $\mathrm{V} 1 \mathrm{~A}$ & & 1 & & 0.0041 & $\begin{array}{l}\text { you found that you could not cope with } \\
\text { all the things that you had to do? } \\
\text { (V1A) In the last month, how often have }\end{array}$ \\
\hline V1AH07 & $\mathrm{V} 1 \mathrm{~A}$ & & 1 & & 0.0048 & $\begin{array}{l}\text { you been able to control irritations } \\
\text { in your life? }\end{array}$ \\
\hline V1AH08 & $\mathrm{V} 1 \mathrm{~A}$ & & 1 & & 0.0048 & $\begin{array}{l}\text { (V1A) In the last month, how often have } \\
\text { you felt that you were on top of things? } \\
\text { (V1A) In the last month, how often have }\end{array}$ \\
\hline V1AH09 & $\mathrm{V} 1 \mathrm{~A}$ & & 1 & & 0.0045 & $\begin{array}{l}\text { you been angered because of things that } \\
\text { were outside of your control? }\end{array}$ \\
\hline V1AH10 & V1A & & 1 & & 0.0043 & $\begin{array}{l}\text { (V1A) In the last month, how often have } \\
\text { you felt difficulties were piling up so } \\
\text { high that you could not overcome them? }\end{array}$ \\
\hline
\end{tabular}


medRxiv preprint doi: https://doi.org/10.1101/2021.08.24.21262142; this version posted August 26, 2021. The copyright holder for this preprint (which was not certified by peer review) is the author/funder, who has granted medRxiv a license to display the preprint in perpetuity.

It is made available under a CC-BY-NC-ND 4.0 International license.

\begin{tabular}{|c|c|c|c|c|c|c|}
\hline NAME & FILE & RULE & TEMPORAL & IMPUTE & MISSING & DESCRIPTION \\
\hline V1C_DEPRESSION_SUMMARY & $\mathrm{V} 1 \mathrm{C}$ & ADD & 1 & MEAN & & \\
\hline V1CA01 & $\mathrm{V} 1 \mathrm{C}$ & & 1 & & 0.0003 & $\begin{array}{l}\text { (V1C) Edinburgh Postnatal Depression } \\
\text { Scale - I have been able to laugh } \\
\text { and see the funny side of things } \\
\text { (V1C) Edinburgh Postnatal Depression }\end{array}$ \\
\hline V1CA02 & $\mathrm{V} 1 \mathrm{C}$ & & 1 & & 0.0004 & $\begin{array}{l}\text { Scale - I have looked forward } \\
\text { with enjoyment to things. } \\
\text { (V1C) Edinburgh Postnatal Depression }\end{array}$ \\
\hline V1CA03 & $\mathrm{V} 1 \mathrm{C}$ & & 1 & & 0.0005 & $\begin{array}{l}\text { Scale - I have blamed myself } \\
\text { unnecessarily when things went wrong. } \\
\text { (V1C) Edinburgh Postnatal Depression }\end{array}$ \\
\hline V1CA04 & $\mathrm{V} 1 \mathrm{C}$ & & 1 & & 0.0006 & $\begin{array}{l}\text { Scale - I have been anxious or } \\
\text { worried for no good reason. } \\
\text { (V1C) Edinburgh Postnatal Depression }\end{array}$ \\
\hline V1CA05 & $\mathrm{V} 1 \mathrm{C}$ & & 1 & & 0.0003 & $\begin{array}{l}\text { Scale - I have felt scared or panicky } \\
\text { for no very good reason. } \\
\text { (V1C) Edinburgh Postnatal Depression }\end{array}$ \\
\hline V1CA06 & V1C & & 1 & & 0.0041 & $\begin{array}{l}\text { Scale - Things have been getting } \\
\text { on top of me. } \\
\text { (V1C) Edinburgh Postnatal Depression }\end{array}$ \\
\hline V1CA07 & $\mathrm{V} 1 \mathrm{C}$ & & 1 & & 0.004 & $\begin{array}{l}\text { Scale - I have been so unhappy that I } \\
\text { have had difficulty sleeping. }\end{array}$ \\
\hline V1CA08 & $\mathrm{V} 1 \mathrm{C}$ & & 1 & & 0.004 & $\begin{array}{l}\text { (V1C) Edinburgh Postnatal Depression } \\
\text { Scale - I have felt sad or miserable. } \\
\text { (V1C) Edinburgh Postnatal Depression }\end{array}$ \\
\hline V1CA09 & $\mathrm{V} 1 \mathrm{C}$ & & 1 & & 0.004 & $\begin{array}{l}\text { Scale - I have been so unhappy that } \\
\text { I have been crying. } \\
\text { (V1C) Edinburgh Postnatal Depression }\end{array}$ \\
\hline V1CA10 & $\mathrm{V} 1 \mathrm{C}$ & & 1 & & 0.0038 & $\begin{array}{l}\text { Scale - The thought of harming myself } \\
\text { has occurred to me. }\end{array}$ \\
\hline V1G_SOCIAL_SCALE & V1G & ADD & 1 & MEAN & & \\
\hline V1GA01 & V1G & & 1 & & 0.0008 & $\begin{array}{l}\text { (V1G) Social Support - There is a } \\
\text { special person who is around } \\
\text { when I am in need }\end{array}$ \\
\hline V1GA02 & V1G & & 1 & & 0.0005 & $\begin{array}{l}\text { (V1G) Social Support - There is a } \\
\text { special person with whom I can } \\
\text { share my joys and sorrows }\end{array}$ \\
\hline V1GA03 & V1G & & 1 & & 0.0019 & $\begin{array}{l}\text { (V1G) Social Support - My family } \\
\text { really tries to help me } \\
\text { (V1G) Social Support - I get the }\end{array}$ \\
\hline V1GA04 & V1G & & 1 & & 0.0008 & $\begin{array}{l}\text { emotional help and support } \\
\text { I need from my family }\end{array}$ \\
\hline V1GA05 & V1G & & 1 & & 0.0009 & $\begin{array}{l}\text { (V1G) Social Support - I have a } \\
\text { special person who is a real } \\
\text { source of comfort to me }\end{array}$ \\
\hline V1GA06 & $\mathrm{V} 1 \mathrm{G}$ & & 1 & & 0.0006 & $\begin{array}{l}\text { (V1G) Social Support - My friends } \\
\text { really try to help me }\end{array}$ \\
\hline V1GA07 & V1G & & 1 & & 0.001 & $\begin{array}{l}\text { (V1G) Social Support - I can count } \\
\text { on my friends when things go wrong }\end{array}$ \\
\hline V1GA08 & V1G & & 1 & & 0.0006 & $\begin{array}{l}\text { (V1G) Social Support - I can talk } \\
\text { about my problems with my family } \\
\text { (V1G) Social Support - I have friends }\end{array}$ \\
\hline V1GA09 & V1G & & 1 & & 0.0013 & $\begin{array}{l}\text { with whom I can share my } \\
\text { joys and sorrows }\end{array}$ \\
\hline V1GA10 & V1G & & 1 & & 0.0007 & $\begin{array}{l}\text { (V1G) Social Support - There is a } \\
\text { special person in my life who } \\
\text { cares about my feelings }\end{array}$ \\
\hline V1GA11 & V1G & & 1 & & 0.0013 & $\begin{array}{l}\text { (V1G) Social Support - My family } \\
\text { is willing to help me make decisions }\end{array}$ \\
\hline V1GA12 & V1G & & 1 & & 0.0006 & $\begin{array}{l}\text { (V1G) Social Support - I can talk } \\
\text { about my problems with my friends }\end{array}$ \\
\hline
\end{tabular}


medRxiv preprint doi: https://doi.org/10.1101/2021.08.24.21262142; this version posted August 26, 2021. The copyright holder for this preprint (which was not certified by peer review) is the author/funder, who has granted medRxiv a license to display the preprint in perpetuity.

It is made available under a CC-BY-NC-ND 4.0 International license .

\begin{tabular}{|c|c|c|c|c|c|c|}
\hline NAME & FILE & RULE & TEMPORAL & IMPUTE & MISSING & DESCRIPTION \\
\hline V2I_RESELIENCE_SUMMARY & V2I & ADD & 2 & MEAN & & \\
\hline V2IA01 & V2I & & 2 & & 0.0006 & (V2I) Able to adapt to change \\
\hline V2IA02 & V2I & & 2 & & 0.0004 & (V2I) Close and secure relationships \\
\hline V2IA03 & V2I & & 2 & & 0.0021 & (V2I) Sometimes fate or God can help \\
\hline V2IA04 & V2I & & 2 & & 0.0004 & (V2I) Can deal with whatever comes \\
\hline V2IA05 & V2I & & 2 & & 0.0015 & $\begin{array}{l}\text { (V2I) Past success gives confidence } \\
\text { for new challenge }\end{array}$ \\
\hline V2IA06 & V2I & & 2 & & 0.0009 & (V2I) See the humorous side of things \\
\hline V2IA07 & V2I & & 2 & & 0.001 & (V2I) Coping with stress strengthens \\
\hline V2IA08 & V2I & & 2 & & 0.0008 & $\begin{array}{l}\text { (V2I) Tend to bounce back after } \\
\text { illness or hardship }\end{array}$ \\
\hline V2IA09 & V2I & & 2 & & 0.0013 & (V2I) Things happen for a reason \\
\hline V2IA10 & V2I & & 2 & & 0.0004 & (V2I) Best effort no matter what \\
\hline V2IA11 & $\mathrm{V} 2 \mathrm{I}$ & & 2 & & 0.0006 & (V2I) You can achieve your goals \\
\hline V2IA12 & V2I & & 2 & & 0.0004 & $\begin{array}{l}\text { (V2I) When things look hopeless, } \\
\text { I don't give up }\end{array}$ \\
\hline V2IA13 & V2I & & 2 & & 0.0006 & (V2I) Know where to turn for help \\
\hline V2IA14 & V2I & & 2 & & 0.0006 & $\begin{array}{l}\text { (V2I) Under pressure, focus and } \\
\text { think clearly }\end{array}$ \\
\hline V2IA15 & V2I & & 2 & & 0.0059 & $\begin{array}{l}\text { (V2I) Prefer to take the lead in } \\
\text { problem solving }\end{array}$ \\
\hline V2IA16 & V2I & & 2 & & 0.0063 & (V2I) Not easily discouraged by failure \\
\hline V2IA17 & V2I & & 2 & & 0.0083 & (V2I) Think of self as strong person \\
\hline V2IA18 & V2I & & 2 & & 0.0064 & $\begin{array}{l}\text { (V2I) Make unpopular or difficult } \\
\text { decisions }\end{array}$ \\
\hline V2IA19 & V2I & & 2 & & 0.0062 & (V2I) Can handle unpleasant feelings \\
\hline V2IA20 & V2I & & 2 & & 0.0063 & (V2I) Have to act on a hunch \\
\hline V2IA21 & V2I & & 2 & & 0.0062 & (V2I) Strong sense of purpose \\
\hline V2IA22 & V2I & & 2 & & 0.0061 & (V2I) In control of your life \\
\hline V2IA23 & V2I & & 2 & & 0.0063 & (V2I) I like challenges \\
\hline V2IA24 & V2I & & 2 & & 0.006 & (V2I) You work to attain your goals \\
\hline V2IA25 & V2I & & 2 & & 0.0061 & (V2I) Pride in your achievements \\
\hline V3A_STRESS_SUMMARY & V3A & ADD & 3 & MEAN & & \\
\hline V3AG01 & V3A & & 3 & & 0.0016 & $\begin{array}{l}\text { (V3A) Perceived Stress Scale - In the } \\
\text { last month, how often have you been } \\
\text { upset because of something that } \\
\text { happened unexpectedly? }\end{array}$ \\
\hline V3AG02 & V3A & & 3 & & 0.0014 & $\begin{array}{l}\text { (V3A) Perceived Stress Scale - In the } \\
\text { last month, how often have you felt } \\
\text { that you were unable to control the } \\
\text { important things in your life? }\end{array}$ \\
\hline V3AG03 & V3A & & 3 & & 0.0014 & $\begin{array}{l}\text { (V3A) Perceived Stress Scale - In the } \\
\text { last month, how often have you } \\
\text { felt nervous and 'stressed'? }\end{array}$ \\
\hline V3AG04 & V3A & & 3 & & 0.0016 & $\begin{array}{l}\text { (V3A) Perceived Stress Scale - In the } \\
\text { last month, how often have you felt } \\
\text { confident about your ability to } \\
\text { handle your personal problems? } \\
\text { (V3A) Perceived Stress Scale - In the }\end{array}$ \\
\hline V3AG05 & V3A & & 3 & & 0.0016 & $\begin{array}{l}\text { last month, how often have you felt } \\
\text { that things were going your way? } \\
\text { (V3A) Perceived Stress Scale - In the }\end{array}$ \\
\hline V3AG06 & V3A & & 3 & & 0.0017 & $\begin{array}{l}\text { last month, how often have you } \\
\text { found that you could not cope with } \\
\text { all the things that you had to do? } \\
\text { (V3A) Perceived Stress Scale - In the }\end{array}$ \\
\hline V3AG07 & V3A & & 3 & & 0.0028 & $\begin{array}{l}\text { last month, how often have you been } \\
\text { able to control irritations in your life? } \\
\text { (V3A) Perceived Stress Scale - In the }\end{array}$ \\
\hline V3AG08 & V3A & & 3 & & 0.002 & $\begin{array}{l}\text { last month, how often have you felt } \\
\text { that you were on top of things? }\end{array}$ \\
\hline V3AG09 & V3A & & 3 & & 0.0015 & $\begin{array}{l}\text { (V3A) Perceived Stress Scale - In the } \\
\text { last month, how often have you been } \\
\text { angered because of things that } \\
\text { were outside of your control? }\end{array}$ \\
\hline V3AG10 & V3A & & 3 & & 0.0015 & $\begin{array}{l}\text { (V3A) Perceived Stress Scale - In the } \\
\text { last month, how often have you felt } \\
\text { difficulties were piling up so high } \\
\text { that you could not overcome them? }\end{array}$ \\
\hline
\end{tabular}


medRxiv preprint doi: https://doi.org/10.1101/2021.08.24.21262142; this version posted August 26, 2021. The copyright holder for this preprint (which was not certified by peer review) is the author/funder, who has granted medRxiv a license to display the preprint in perpetuity.

\section{It is made available under a CC-BY-NC-ND 4.0 International license .}

\begin{tabular}{|c|c|c|c|c|c|c|}
\hline NAME & FILE & RULE & TEMPORAL & IMPUTE & MISSING & DESCRIPTION \\
\hline V3C_DEPRESSION_SUMMARY & V3C & ADD & 3 & MEAN & & \\
\hline V3CA01 & $\mathrm{V} 3 \mathrm{C}$ & & 3 & & 0.0007 & $\begin{array}{l}\text { (V3C) Edinburgh Postnatal Depression } \\
\text { Scale - I have been able to laugh and } \\
\text { see the funny side of things } \\
\text { (V3C) Edinburgh Postnatal Depression }\end{array}$ \\
\hline V3CA02 & $\mathrm{V} 3 \mathrm{C}$ & & 3 & & 0.0007 & $\begin{array}{l}\text { Scale - I have looked forward with } \\
\text { enjoyment to things. } \\
\text { (V3C) Edinburgh Postnatal Depression }\end{array}$ \\
\hline V3CA03 & V3C & & 3 & & 0.0007 & $\begin{array}{l}\text { Scale - I have blamed myself } \\
\text { unnecessarily when things went wrong. } \\
\text { (V3C) Edinburgh Postnatal Depression }\end{array}$ \\
\hline V3CA04 & V3C & & 3 & & 0.0008 & $\begin{array}{l}\text { Scale - I have been anxious or worried } \\
\text { for no good reason. } \\
\text { (V3C) Edinburgh Postnatal Depression }\end{array}$ \\
\hline V3CA05 & $\mathrm{V} 3 \mathrm{C}$ & & 3 & & 0.0009 & $\begin{array}{l}\text { Scale - I have felt scared or panicky } \\
\text { for no very good reason. } \\
\text { (V3C) Edinburgh Postnatal Depression }\end{array}$ \\
\hline V3CA06 & V3C & & 3 & & 0.0064 & $\begin{array}{l}\text { Scale - Things have been getting } \\
\text { on top of me. } \\
\text { (V3C) Edinburgh Postnatal Depression }\end{array}$ \\
\hline V3CA07 & V3C & & 3 & & 0.006 & $\begin{array}{l}\text { Scale - I have been so unhappy that } \\
\text { I have had difficulty sleeping. }\end{array}$ \\
\hline V3CA08 & $\mathrm{V} 3 \mathrm{C}$ & & 3 & & 0.0059 & $\begin{array}{l}\text { (V3C) Edinburgh Postnatal Depression } \\
\text { Scale - I have felt sad or miserable. } \\
\text { (V3C) Edinburgh Postnatal Depression }\end{array}$ \\
\hline V3CA09 & $\mathrm{V} 3 \mathrm{C}$ & & 3 & & 0.0059 & $\begin{array}{l}\text { Scale - I have been so unhappy } \\
\text { that I have been crying. } \\
\text { (V3C) Edinburgh Postnatal Depression }\end{array}$ \\
\hline V3CA10 & V3C & & 3 & & 0.0059 & $\begin{array}{l}\text { Scale - The thought of harming myself } \\
\text { has occurred to me. }\end{array}$ \\
\hline
\end{tabular}

Psychological Filtering 


\subsection{Activity}

The activity filtering related to details about participant physical activity prior to and during pregnancy. The activities were measured in METs, or metabolic equivalents, for Layer 1 and expanded upon in further detail, namely activity type, minutes, miles and duration in Layer 2. Activity restriction information available at V3 and V4 was also included, to account for influence on the MET score.

Total \# Features: 131

Layer 1 \# Features: 3

Layer 2 \# Features: 22

Relevant Files: physical_activity (ancillary), V1A, V2A, V3A, V4A

Dropped Features: We chose to discard features relating to any personal or care provider weight change goals, as these were suggestions that would merely be reflected in the actual activity data.

Table 7: Activity Filtering

\begin{tabular}{|c|c|c|c|c|c|c|}
\hline NAME & FILE & RULE & TEMPORAL & IMPUTE & MISSING & DESCRIPTION \\
\hline Visit1_MET & physical_activity & & 1 & mean & 0 & Visit 1 MET Equivalents \\
\hline Visit2_MET & physical_activity & & 2 & mean & 0 & Visit 2 MET Equivalents \\
\hline Visit3_MET & physical_activity & & 3 & mean & 0 & Visit 3 MET Equivalents \\
\hline V1A_ACTIVITY_1 & V1A & V1AI01 & 1 & onehot & 0.001 & $\begin{array}{l}\text { During the past } 4 \text { weeks, did } \\
\text { you participate in any } \\
\text { physical activities? }\end{array}$ \\
\hline V1A_ACTIVITY_1_code & $\mathrm{V} 1 \mathrm{~A}$ & V1AI01a & 1 & onehot & 0.2987 & $\begin{array}{l}\text { (Activity \#1) - Code } \\
\text { How many times per week did }\end{array}$ \\
\hline V1A_ACTIVITY_1_weekly & V1A & V1AI01a1 & 1 & mean & 0.2991 & $\begin{array}{l}\text { you take part in this activity } \\
\text { during the past } 4 \text { weeks? }\end{array}$ \\
\hline V1A_ACTIVITY_1_minutes & V1A & V1AI01a2 & 1 & mean & 0.3063 & $\begin{array}{l}\text { And when you took part in this } \\
\text { activity, for how many minutes } \\
\text { did you usually keep at it? }\end{array}$ \\
\hline V1A_ACTIVITY_1_miles & V1A & V1AI01a3 & 1 & mean & 0.6079 & $\begin{array}{l}\text { How far do you usually } \\
\text { walk/run/jog/cycle/swim? } \\
\text { (Activity \#1) - miles }\end{array}$ \\
\hline V1A_ACTIVITY_2 & V1A & V1AI02 & 1 & onehot & 0.3016 & $\begin{array}{l}\text { During the past } 4 \text { weeks, did } \\
\text { you participate in any } \\
\text { physical activities? }\end{array}$ \\
\hline V1A_ACTIVITY_2_code & V1A & V1AI02a & 1 & onehot & 0.7045 & (Activity \#2) - Code \\
\hline V1A_ACTIVITY_2_weekly & V1A & V1AI02a1 & 1 & mean & 0.7051 & $\begin{array}{l}\text { How many times per week did } \\
\text { you take part in this activity } \\
\text { during the past } 4 \text { weeks? }\end{array}$ \\
\hline V1A_ACTIVITY_2_minutes & V1A & V1AI02a2 & 1 & mean & 0.7074 & $\begin{array}{l}\text { And when you took part in this } \\
\text { activity, for how many minutes } \\
\text { did you usually keep at it? }\end{array}$ \\
\hline V1A_ACTIVITY_2_miles & $\mathrm{V} 1 \mathrm{~A}$ & V1AI02a3 & 1 & mean & 0.9092 & $\begin{array}{l}\text { How far do you usually } \\
\text { walk/run/jog/cycle/swim? } \\
\text { (Activity \#2) - miles }\end{array}$ \\
\hline V1A_ACTIVITY_3 & V1A & V1AI03 & 1 & onehot & 0.7083 & $\begin{array}{l}\text { During the past } 4 \text { weeks, did } \\
\text { you participate in any } \\
\text { physical activities? }\end{array}$ \\
\hline V1A_ACTIVITY_3_code & $\mathrm{V} 1 \mathrm{~A}$ & V1AI03a & 1 & onehot & 0.8957 & (Activity \#3) - Code \\
\hline V1A_ACTIVITY_3_weekly & V1A & V1AI03a1 & 1 & mean & 0.8961 & $\begin{array}{l}\text { How many times per week did } \\
\text { you take part in this } \\
\text { activity during the past } 4 \text { weeks? }\end{array}$ \\
\hline V1A_ACTIVITY_3_minutes & $\mathrm{V} 1 \mathrm{~A}$ & V1AI03a2 & 1 & mean & 0.8965 & $\begin{array}{l}\text { And when you took part in this } \\
\text { activity, for how many minutes } \\
\text { did you usually keep at it? }\end{array}$ \\
\hline V1A_ACTIVITY_3_miles & V1A & V1AI03a3 & 1 & mean & 0.9733 & $\begin{array}{l}\text { How far do you usually } \\
\text { walk/run/jog/cycle/swim? } \\
\text { (Activity \#3) - miles }\end{array}$ \\
\hline V2A_ACTIVITY_1 & $\mathrm{V} 2 \mathrm{~A}$ & V2AJ01 & 2 & onehot & 0.0003 & $\begin{array}{l}\text { During the past } 4 \text { weeks, did } \\
\text { you participate in any } \\
\text { physical activities? }\end{array}$ \\
\hline V2A_ACTIVITY_1_code & $\mathrm{V} 2 \mathrm{~A}$ & V2AJ01a & 2 & onehot & 0.2581 & (Activity \#1) - Code \\
\hline V2A_ACTIVITY_1_weekly & $\mathrm{V} 2 \mathrm{~A}$ & V2AJ01a1 & 2 & mean & 0.2592 & $\begin{array}{l}\text { How many times per week did } \\
\text { you take part in this activity } \\
\text { during the past } 4 \text { weeks? }\end{array}$ \\
\hline
\end{tabular}


medRxiv preprint doi: https://doi.org/10.1101/2021.08.24.21262142; this version posted August 26, 2021. The copyright holder for this preprint (which was not certified by peer review) is the author/funder, who has granted medRxiv a license to display the preprint in perpetuity.

It is made available under a CC-BY-NC-ND 4.0 International license .

\begin{tabular}{|c|c|c|c|c|c|c|}
\hline NAME & FILE & RULE & TEMPORAL & IMPUTE & MISSING & DESCRIPTION \\
\hline V2A_ACTIVITY_1_minutes & $\mathrm{V} 2 \mathrm{~A}$ & V2AJ01a2 & 2 & mean & 0.2695 & $\begin{array}{l}\text { And when you took part in this } \\
\text { activity, for how many minutes } \\
\text { did you usually keep at it? }\end{array}$ \\
\hline V2A_ACTIVITY_1_miles & $\mathrm{V} 2 \mathrm{~A}$ & V2AJ01a3 & 2 & mean & 0.5907 & $\begin{array}{l}\text { How far do you usually } \\
\text { walk/run/jog/cycle/swim? } \\
\text { (Activity \#1) - miles }\end{array}$ \\
\hline V2A_ACTIVITY_2 & $\mathrm{V} 2 \mathrm{~A}$ & V2AJ02 & 2 & onehot & 0.258 & $\begin{array}{l}\text { During the past } 4 \text { weeks, did } \\
\text { you participate in any } \\
\text { physical activities? }\end{array}$ \\
\hline V2A_ACTIVITY_2_code & $\mathrm{V} 2 \mathrm{~A}$ & V2AJ02a & 2 & onehot & 0.696 & (Activity \#2) - Code \\
\hline V2A_ACTIVITY_2_weekly & $\mathrm{V} 2 \mathrm{~A}$ & V2AJ02a1 & 2 & mean & 0.6972 & $\begin{array}{l}\text { How many times per week did } \\
\text { you take part in this activity } \\
\text { during the past } 4 \text { weeks? }\end{array}$ \\
\hline V2A_ACTIVITY_2_minutes & $\mathrm{V} 2 \mathrm{~A}$ & V2AJ02a2 & 2 & mean & 0.7003 & $\begin{array}{l}\text { And when you took part in this } \\
\text { activity, for how many minutes } \\
\text { did you usually keep at it? }\end{array}$ \\
\hline V2A_ACTIVITY_2_miles & $\mathrm{V} 2 \mathrm{~A}$ & V2AJ02a3 & 2 & mean & 0.911 & $\begin{array}{l}\text { How far do you usually } \\
\text { walk/run/jog/cycle/swim? } \\
\text { (Activity \#2) - miles }\end{array}$ \\
\hline V2A_ACTIVITY_3 & $\mathrm{V} 2 \mathrm{~A}$ & V2AJ03 & 2 & onehot & 0.6924 & $\begin{array}{l}\text { During the past } 4 \text { weeks, did } \\
\text { you participate in any } \\
\text { physical activities? }\end{array}$ \\
\hline V2A_ACTIVITY_3_code & $\mathrm{V} 2 \mathrm{~A}$ & V2AJ03a & 2 & onehot & 0.9019 & (Activity \#3) - Code \\
\hline V2A_ACTIVITY_3_weekly & $\mathrm{V} 2 \mathrm{~A}$ & V2AJ03a1 & 2 & mean & 0.902 & $\begin{array}{l}\text { How many times per week did } \\
\text { you take part in this activity } \\
\text { during the past } 4 \text { weeks? }\end{array}$ \\
\hline V2A_ACTIVITY_3_minutes & $\mathrm{V} 2 \mathrm{~A}$ & V2AJ03a2 & 2 & mean & 0.9031 & $\begin{array}{l}\text { And when you took part in this } \\
\text { activity, for how many minutes } \\
\text { did you usually keep at it? }\end{array}$ \\
\hline V2A_ACTIVITY_3_miles & $\mathrm{V} 2 \mathrm{~A}$ & V2AJ03a3 & 2 & mean & 0.978 & $\begin{array}{l}\text { How far do you usually } \\
\text { walk/run/jog/cycle/swim? } \\
\text { (Activity \#3) - miles }\end{array}$ \\
\hline V3A_ACTIVITY_1 & V3A & V3AH01 & 3 & onehot & 0.0002 & $\begin{array}{l}\text { During the past } 4 \text { weeks, did } \\
\text { you participate in any } \\
\text { physical activities? }\end{array}$ \\
\hline V3A_ACTIVITY_1_code & V3A & V3AH01a & 3 & onehot & 0.2896 & (Activity \#1) - Code \\
\hline V3A_ACTIVITY_1_weekly & V3A & V3AH01a1 & 3 & mean & 0.2906 & $\begin{array}{l}\text { How many times per week did } \\
\text { you take part in this activity } \\
\text { during the past } 4 \text { weeks? }\end{array}$ \\
\hline V3A_ACTIVITY_1_minutes & $\mathrm{V} 3 \mathrm{~A}$ & V3AH01a2 & 3 & mean & 0.3001 & $\begin{array}{l}\text { And when you took part in this } \\
\text { activity, for how many minutes } \\
\text { did you usually keep at it? }\end{array}$ \\
\hline V3A_ACTIVITY_1_miles & V3A & V3AH01a3 & 3 & mean & 0.6231 & $\begin{array}{l}\text { How far do you usually } \\
\text { walk/run/jog/cycle/swim? } \\
\text { (Activity \#1) - miles }\end{array}$ \\
\hline V3A_ACTIVITY_2 & V3A & V3AH02 & 3 & onehot & 0.289 & $\begin{array}{l}\text { During the past } 4 \text { weeks, did } \\
\text { you participate in any } \\
\text { physical activities? }\end{array}$ \\
\hline V3A_ACTIVITY_2_code & V3A & V3AH02a & 3 & onehot & 0.739 & (Activity \#2) - Code \\
\hline V3A_ACTIVITY_2_weekly & V3A & V3AH02a1 & 3 & mean & 0.7392 & $\begin{array}{l}\text { How many times per week did } \\
\text { you take part in this activity } \\
\text { during the past } 4 \text { weeks? }\end{array}$ \\
\hline V3A_ACTIVITY_2_minutes & $\mathrm{V} 3 \mathrm{~A}$ & V3AH02a2 & 3 & mean & 0.7411 & $\begin{array}{l}\text { And when you took part in this } \\
\text { activity, for how many minutes } \\
\text { did you usually keep at it? }\end{array}$ \\
\hline V3A_ACTIVITY_2_miles & $\mathrm{V} 3 \mathrm{~A}$ & V3AH02a3 & 3 & mean & 0.9277 & $\begin{array}{l}\text { How far do you usually } \\
\text { walk/run/jog/cycle/swim? } \\
\text { (Activity \#2) - miles }\end{array}$ \\
\hline V3A_ACTIVITY_3 & $\mathrm{V} 3 \mathrm{~A}$ & V3AH03 & 3 & onehot & 0.7376 & $\begin{array}{l}\text { During the past } 4 \text { weeks, did } \\
\text { you participate in any } \\
\text { physical activities? }\end{array}$ \\
\hline V3A_ACTIVITY_3_code & $\mathrm{V} 3 \mathrm{~A}$ & V3AH03a & 3 & onehot & 0.923 & (Activity \#3) - Code \\
\hline V3A_ACTIVITY_3_weekly & V3A & V3AH03a1 & 3 & mean & 0.923 & $\begin{array}{l}\text { How many times per week did } \\
\text { you take part in this activity } \\
\text { during the past } 4 \text { weeks? }\end{array}$ \\
\hline
\end{tabular}


medRxiv preprint doi: https://doi.org/10.1101/2021.08.24.21262142; this version posted August 26, 2021. The copyright holder for this preprint (which was not certified by peer review) is the author/funder, who has granted medRxiv a license to display the preprint in perpetuity.

It is made available under a CC-BY-NC-ND 4.0 International license.

\begin{tabular}{lcccccl} 
NAME & FILE & RULE & TEMPORAL & IMPUTE & MISSING & DESCRIPTION \\
\hline V3A_ACTIVITY_3_minutes & V3A & V3AH03a2 & 3 & mean & 0.9234 & $\begin{array}{l}\text { And when you took part in this } \\
\text { activity, for how many minutes } \\
\text { did you usually keep at it? }\end{array}$ \\
V3A_ACTIVITY_3_miles & V3A & V3AH03a3 & 3 & mean & 0.9817 & $\begin{array}{l}\text { How far do you usually } \\
\text { walk/run/jog/cycle/swim? } \\
\text { (Activity } \# 3) \text { miles } \\
\text { (V3A) Has a care provider } \\
\text { told you to restrict your }\end{array}$ \\
V3AD07 & V3A & & 3 & mode & 0.0435 & $\begin{array}{l}\text { activity in any way? } \\
\text { (V4A) Before delivery, did a } \\
\text { care provider tell you to } \\
\text { restrict your activity in any way? }\end{array}$
\end{tabular}

Activity Filtering 
medRxiv preprint doi: https://doi.org/10.1101/2021.08.24.21262142; this version posted August 26, 2021. The copyright holder for this preprint (which was not certified by peer review) is the author/funder, who has granted medRxiv a license to display the preprint in perpetuity.

It is made available under a CC-BY-NC-ND 4.0 International license .

\subsection{Demographics}

The demographics filtering includes details about social factors including education and marital status, in addition to the more medically relevant factors of race, healthcare access and stress levels related to partner support.

Total \# Features: 170

Layer 1 \# Features: 21

Layer 2 \# Features: 22

Relevant Files: V1A, V2A

Dropped Features: We chose to discard redundant features such as the racial background of the mother's parents since that information is inherently stored in the mother's race herself. Social constructs like ethnicity and perceived race (by others) were not deemed medically relevant, so those were also removed. Experiences in discrimination would further account for some of their social effects. We also believed that expectations for partner support was a more relevant proxy of social support than questions about the nature of the relationship such as length of relationship.

Table 8: Demographics Filtering

\begin{tabular}{|c|c|c|c|c|c|c|}
\hline NAME & FILE & RULE & TEMPORAL & IMPUTE & MISSING & DESCRIPTION \\
\hline V1AF02 & V1A & & 1 & Mean & 0.0008 & $\begin{array}{l}\text { (V1A) How many years of } \\
\text { education have you completed? }\end{array}$ \\
\hline V1AF03 & V1A & & 1 & Onehot & 0.0015 & $\begin{array}{l}\text { (V1A) Do you currently have a } \\
\text { partner or 'significant other'? }\end{array}$ \\
\hline V1AF04 & V1A & & 1 & Onehot & 0.0015 & $\begin{array}{l}\text { (V1A) What is your current } \\
\text { marital status? }\end{array}$ \\
\hline V1AF05 & V1A & & -1 & Onehot & 0.0001 & $\begin{array}{l}\text { (V1A) Are you of Hispanic or } \\
\text { Latino origin or descent? } \\
\text { (V1A) How many years have }\end{array}$ \\
\hline V1AF09 & V1A & & -1 & Mean & 0.0057 & $\begin{array}{l}\text { you lived in the United States? } \\
\text { - years, } \\
\text { (V1A) How would you rate your }\end{array}$ \\
\hline V1AF10 & V1A & & -1 & Onehot & 0.0005 & \\
\hline V1AF13 & V1A & & -1 & Mean & 0.0018 & $\begin{array}{l}\text { (V1A) Counting yourself, how } \\
\text { many people live in your } \\
\text { household? - people }\end{array}$ \\
\hline V1AF14 & V1A & & -1 & Mean & 0.1893 & $\begin{array}{l}\text { (V1A) Total family income } \\
\text { for the past } 12 \text { months }\end{array}$ \\
\hline V2AF02 & $\mathrm{V} 2 \mathrm{~A}$ & & 2 & Onehot & 0.0007 & $\begin{array}{l}\text { (V2A) Do you currently have a } \\
\text { partner or 'significant other'? }\end{array}$ \\
\hline V2AF02a & $\mathrm{V} 2 \mathrm{~A}$ & & 2 & Onehot & 0.0611 & $\begin{array}{l}\text { (V2A) Are you currently living } \\
\text { with your partner? }\end{array}$ \\
\hline V2AF03 & $\mathrm{V} 2 \mathrm{~A}$ & & 2 & Onehot & 0.0007 & $\begin{array}{l}\text { (V2A) What is your current } \\
\text { marital status? }\end{array}$ \\
\hline V2AF04 & $\mathrm{V} 2 \mathrm{~A}$ & & -1 & Onehot & 0.0048 & $\begin{array}{l}\text { (V2A) Is your mother of Hispanic } \\
\text { or Latino origin or descent? }\end{array}$ \\
\hline V2AF13 & $\mathrm{V} 2 \mathrm{~A}$ & & 2 & Mean & 0.0283 & $\begin{array}{l}\text { (V2A) How old is the father } \\
\text { of the baby? - years }\end{array}$ \\
\hline V2AG01 & $\mathrm{V} 2 \mathrm{~A}$ & & -1 & Onehot & 0.0017 & $\begin{array}{l}\text { treated unfairly, do you usually } \\
\text { accept it as a fact of life and } \\
\text { keep it to yourself? }\end{array}$ \\
\hline V2AG02 & $\mathrm{V} 2 \mathrm{~A}$ & & -1 & Onehot & 0.0019 & $\begin{array}{l}\text { (V2A) If you have been treated } \\
\text { unfairly, do you usually talk to }\end{array}$ \\
\hline
\end{tabular}


medRxiv preprint doi: https://doi.org/10.1101/2021.08.24.21262142; this version posted August 26, 2021. The copyright holder for this preprint (which was not certified by peer review) is the author/funder, who has granted medRxiv a license to display the preprint in perpetuity.

It is made available under a CC-BY-NC-ND 4.0 International license .

\begin{tabular}{|c|c|c|c|c|c|c|}
\hline NAME & FILE & RULE & TEMPORAL & IMPUTE & MISSING & DESCRIPTION \\
\hline V1A & & & & & & \\
\hline $\begin{array}{l}\text { PATIENT } \\
\text { RACE }\end{array}$ & $\mathrm{V} 1 \mathrm{~A}$ & ONEHOT & -1 & Onehot & & \\
\hline V1AF07a & V1A & & -1 & & 0.0004 & \multirow{7}{*}{$\begin{array}{l}\text { (V1A) Racial background - White } \\
\text { (V1A) Racial background - Black, } \\
\text { African American or African Descent } \\
\text { (V1A) Racial background - } \\
\text { American Indian or Alaska Native } \\
\text { (V1A) Racial background - } \\
\text { Asian Indian } \\
\text { (V1A) Racial background - }\end{array}$} \\
\hline V1AF07b & V1A & & -1 & & 0.0004 & \\
\hline $\mathrm{V} 1 \mathrm{AF} 07 \mathrm{c}$ & V1A & & -1 & & 0.0004 & \\
\hline V1AF07d & V1A & & -1 & & 0.0004 & \\
\hline V1AF07e & $\mathrm{V} 1 \mathrm{~A}$ & & -1 & & 0.0004 & \\
\hline V1AF07f & $\mathrm{V} 1 \mathrm{~A}$ & & -1 & & 0.0004 & \\
\hline V1AF07g & $\mathrm{V} 1 \mathrm{~A}$ & & -1 & & 0.0004 & \\
\hline
\end{tabular}

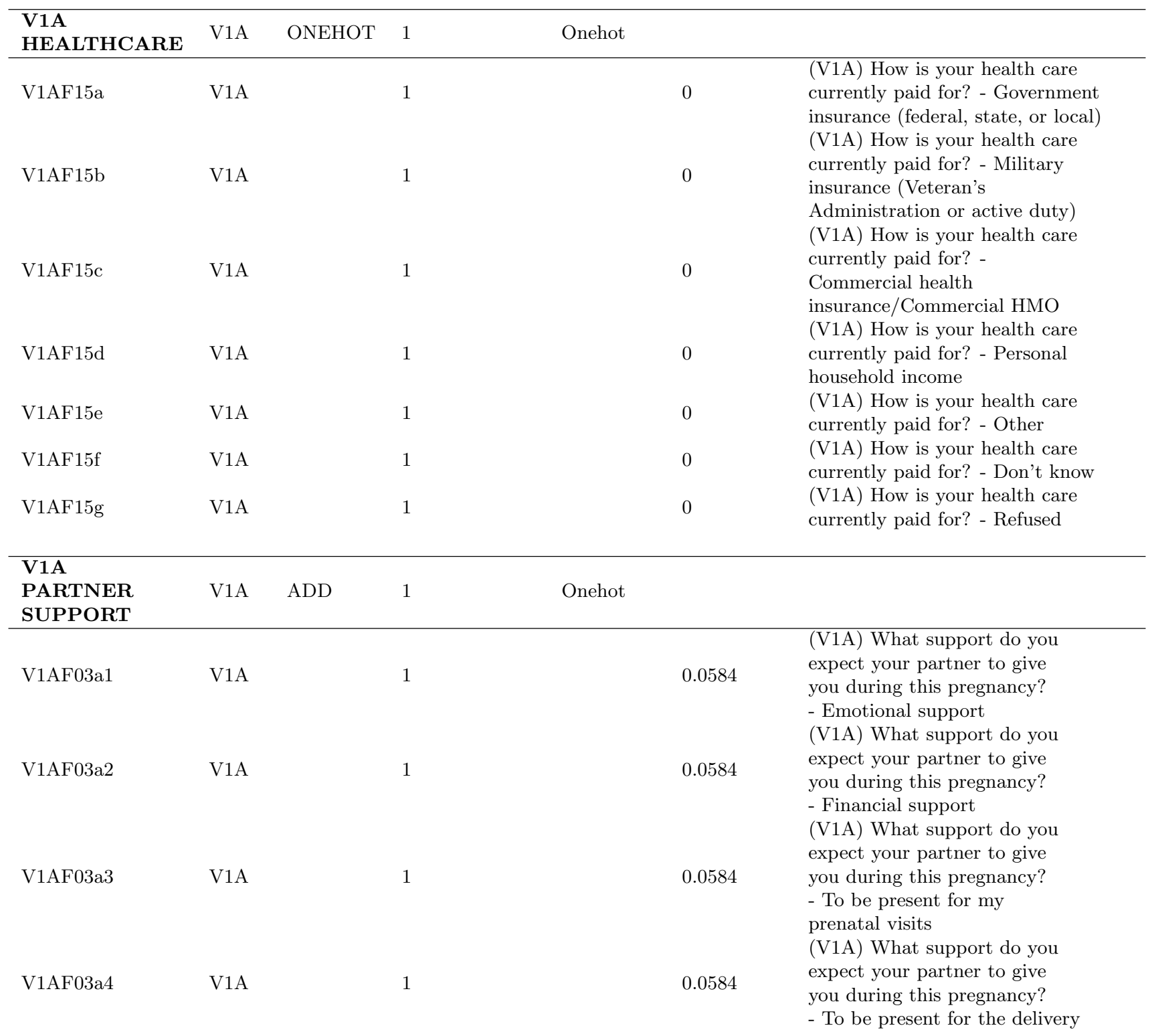


medRxiv preprint doi: https://doi.org/10.1101/2021.08.24.21262142; this version posted August 26, 2021. The copyright holder for this preprint (which was not certified by peer review) is the author/funder, who has granted medRxiv a license to display the preprint in perpetuity.

It is made available under a CC-BY-NC-ND 4.0 International license .

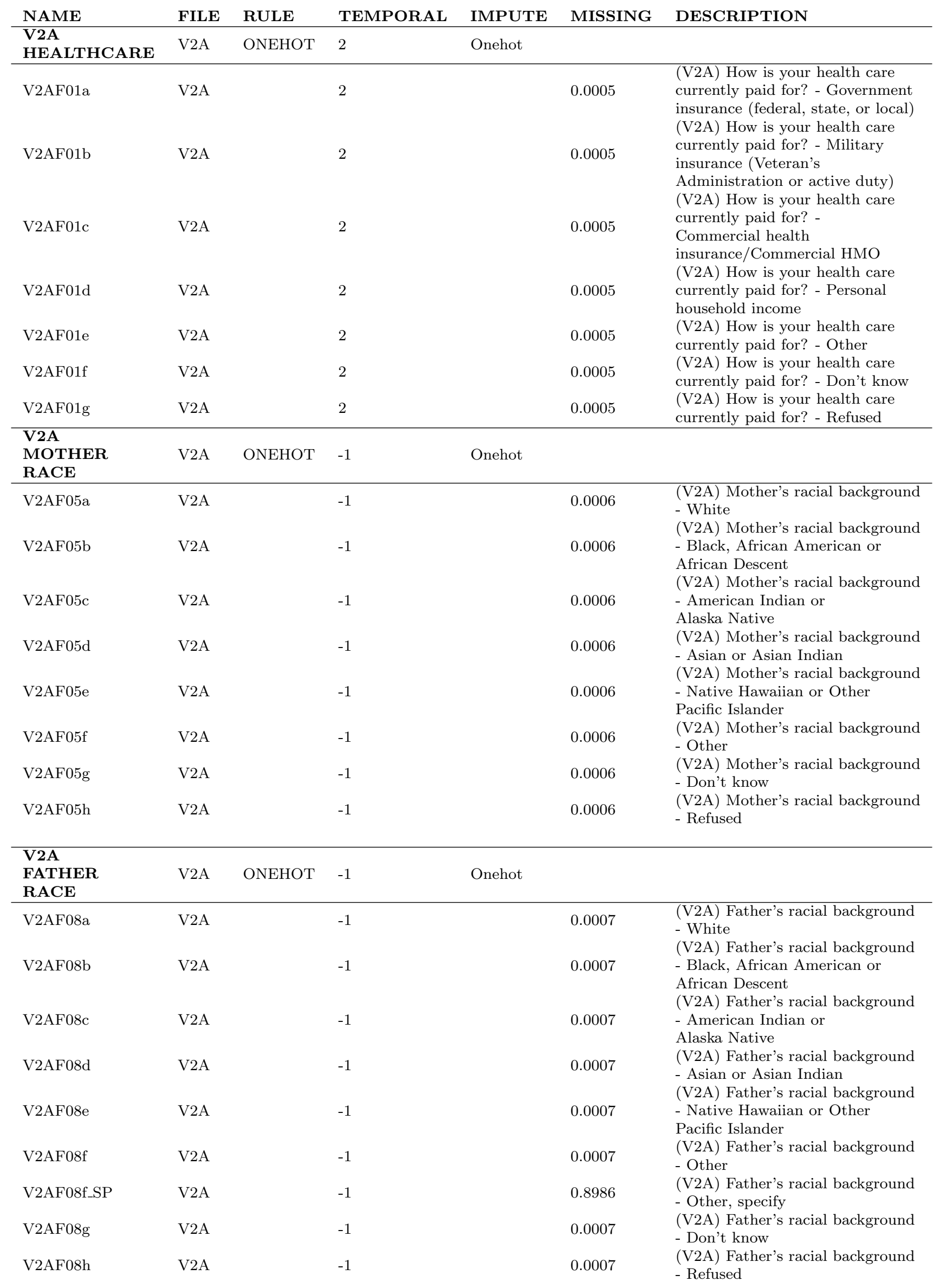


medRxiv preprint doi: https://doi.org/10.1101/2021.08.24.21262142; this version posted August 26, 2021. The copyright holder for this preprint (which was not certified by peer review) is the author/funder, who has granted medRxiv a license to display the preprint in perpetuity.

\section{It is made available under a CC-BY-NC-ND 4.0 International license .}

\begin{tabular}{|c|c|c|c|c|c|c|}
\hline NAME & FILE & RULE & TEMPORAL & IMPUTE & MISSING & DESCRIPTION \\
\hline $\begin{array}{l}\text { V2A } \\
\text { DISCRIMINATION }\end{array}$ & V2A & $\mathrm{ADD}$ & -1 & Mean & & \\
\hline V2AG02 & $\mathrm{V} 2 \mathrm{~A}$ & & -1 & & 0.0019 & $\begin{array}{l}\text { (V2A) If you have been treated } \\
\text { unfairly, do you usually talk to } \\
\text { people or keep it for yourself } \\
\text { (V2A) Have you ever experienced } \\
\text { discrimination, been prevented } \\
\text { from doing something, or been }\end{array}$ \\
\hline V2AG03a & $\mathrm{V} 2 \mathrm{~A}$ & & -1 & & 0.0017 & $\begin{array}{l}\text { hassled or made to feel inferior in } \\
\text { any of the following situations } \\
\text { because of your race, ethnicity, } \\
\text { or color: at school? }\end{array}$ \\
\hline V2AG03b & $\mathrm{V} 2 \mathrm{~A}$ & & -1 & & 0.0017 & $\begin{array}{l}(\mathrm{V} 2 \mathrm{~A}) \text { ' ' Getting hired or } \\
\text { getting a job? }\end{array}$ \\
\hline V2AG03c & $\mathrm{V} 2 \mathrm{~A}$ & & -1 & & 0.0017 & $(\mathrm{~V} 2 \mathrm{~A})^{\prime}$ ' At work? \\
\hline V2AG03d & $\mathrm{V} 2 \mathrm{~A}$ & & -1 & & 0.0017 & (V2A) ' ' Getting housing? \\
\hline V2AG03e & $\mathrm{V} 2 \mathrm{~A}$ & & -1 & & 0.0017 & (V2A)' ' Getting medical care? \\
\hline V2AG03f & V2A & & -1 & & 0.0017 & $\begin{array}{l}(\mathrm{V} 2 \mathrm{~A}) \text { ' ' Getting service in } \\
\text { a store or restaurant? }\end{array}$ \\
\hline V2AG03g & $\mathrm{V} 2 \mathrm{~A}$ & & -1 & & 0.0017 & $\begin{array}{l}\text { (V2A) ' ' Getting credit, } \\
\text { bank loans, or a mortgage? }\end{array}$ \\
\hline V2AG03h & $\mathrm{V} 2 \mathrm{~A}$ & & -1 & & 0.0018 & $\begin{array}{l}\text { (V2A) ' On the street or } \\
\text { in a public setting? }\end{array}$ \\
\hline V2AG03i & $\mathrm{V} 2 \mathrm{~A}$ & & -1 & & 0.0018 & $\begin{array}{l}\text { (V2A)' ' From the police } \\
\text { or in the courts? }\end{array}$ \\
\hline
\end{tabular}

Demographics Filtering 


\subsection{Physiology}

The physiology filtering includes questions regarding the current and recent physiological health and questioning of the patient. This includes factors such as temperature, weight, body measurements, flu-like symptoms, nausea, blood pressure, and recent evidence of contractions or vaginal bleeding.

Total \# Features: 115

Layer 1 \# Features: 38

Layer 2 \# Features: 38

Relevant Files: CMA, CMB, Demographics (ancillary), V1A, V1B, V2A, V2B, V3A, V3B, V4A

Dropped Features: For this group, we chose to exclude features that were detail oriented to questions that were asked earlier in the questionnaire. For example, details on flu-like illness symptoms were dropped, while the general question on if any such illness was present was kept, as the general question implicitly covers the presence of a response in the details that follow. Certain details were added back within L2, such as contraction and vaginal bleeding times. Multiple measurements of the same region were averaged into a single feature. Maximum, rather than average, blood pressure and temperature on admission were kept as they were deemed a better representation of potential risk or medical issues. Metadata features were used to organize data and later dropped.

\begin{tabular}{|c|c|c|c|c|c|c|}
\hline NAME & FILE & RULE & TEMPORAL & IMPUTE & MISSINGNESS & DESCRIPTION \\
\hline CMBC02b1 & $\mathrm{CMB}$ & & $\begin{array}{l}\text { Date } \\
\text { Abstraction }\end{array}$ & Mean & 0.0266 & $\begin{array}{l}\text { (CMB) Blood pressure - Highest systolic blood pressure } \\
\text { during stay }(\mathrm{mmHg})\end{array}$ \\
\hline CMBC02b2 & $\mathrm{CMB}$ & & $\begin{array}{l}\text { Date } \\
\text { Abstraction }\end{array}$ & Mean & 0.0266 & $\begin{array}{l}\text { (CMB) Blood pressure - Highest diastolic blood pressure } \\
\text { during stay }(\mathrm{mmHg}) \text {, }\end{array}$ \\
\hline BMI_Cat & $\begin{array}{l}\text { demographics } \\
\text { (ancillary) }\end{array}$ & & 1 & Bmicat & 0.0225 & $\begin{array}{l}\text { BMI category }\left(\mathrm{kg} / \mathrm{m}^{\wedge} 2\right) \text { at visit } 1 \text { calculated from height and } \\
\text { weight (form } \mathrm{V} 1 \mathrm{~B})\end{array}$ \\
\hline V1AD06 & V1A & & 1 & Any & 0.0004 & $\begin{array}{l}\text { (V1A) Have you had any 'flu-like illnesses,' 'really bad colds,' } \\
\text { fever, a rash } \\
\text {, or any muscle or joint aches since you }\end{array}$ \\
\hline V1AD07 & V1A & & 1 & Mode & 0.0008 & $\begin{array}{l}\text { (V1A) Have you had any cramping since you became } \\
\text { pregnant? }\end{array}$ \\
\hline V1AD08 & V1A & & 1 & Multi & 0.0005 & $\begin{array}{l}\text { (V1A) Since you became pregnant, have you had vaginal } \\
\text { bleeding more } \\
\text { than spotting? }\end{array}$ \\
\hline V1AD09 & V1A & & 1 & Mode & 0.0004 & $\begin{array}{l}\text { (V1A) In the last } 12 \text { hours, for how many hours have you } \\
\text { felt nauseated? }\end{array}$ \\
\hline V1AD10 & V1A & & 1 & Mode & 0.0003 & $\begin{array}{l}\text { (V1A) In the last } 12 \text { hours, how many times have you } \\
\text { vomited? }\end{array}$ \\
\hline V1AD11 & $\mathrm{V} 1 \mathrm{~A}$ & & 1 & Mode & 0.0003 & $\begin{array}{l}\text { (V1A) In the last } 12 \text { hours, how many times have you had } \\
\text { retching or dry heaves } \\
\text { without emesis (vomiting)? }\end{array}$ \\
\hline V2AD01 & $\mathrm{V} 2 \mathrm{~A}$ & & 2 & Any & 0.0008 & $\begin{array}{l}\text { (V2A) Have you had any 'flu-like illnesses,' 'really bad colds,' } \\
\text { fever, a rash, or } \\
\text { any muscle or joint aches since last study }\end{array}$ \\
\hline V2AD02 & $\mathrm{V} 2 \mathrm{~A}$ & & 2 & Single & 0.001 & $\begin{array}{l}\text { (V2A) Have you had any cramping/contractions since last } \\
\text { study visit? }\end{array}$ \\
\hline V2AD03 & $\mathrm{V} 2 \mathrm{~A}$ & & 2 & Multi & 0.001 & $\begin{array}{l}\text { (V2A) Since last study visit, have you had vaginal bleeding } \\
\text { more than spotting? }\end{array}$ \\
\hline V2AD04 & $\mathrm{V} 2 \mathrm{~A}$ & & 2 & Mode & 0.0012 & $\begin{array}{l}\text { (V2A) In the last } 12 \text { hours, for how many hours have you felt } \\
\text { nauseated? }\end{array}$ \\
\hline V2AD05 & $\mathrm{V} 2 \mathrm{~A}$ & & 2 & Mode & 0.0012 & $\begin{array}{l}\text { (V2A) In the last } 12 \text { hours, how many times have you vomited? } \\
\text { (V2A) In the last } 12 \text { hours, how many times have you had }\end{array}$ \\
\hline V2AD06 & $\mathrm{V} 2 \mathrm{~A}$ & & 2 & Mode & 0.0013 & $\begin{array}{l}\text { retching or dry heaves } \\
\text { without emesis (vomiting)? }\end{array}$ \\
\hline V3AD01 & V3A & & 3 & Any & 0.0001 & $\begin{array}{l}\text { (V3A) Have you had any 'flu-like illnesses,' 'really bad colds,' } \\
\text { fever, a rash, or any } \\
\text { muscle or joint aches since last study }\end{array}$ \\
\hline V3AD02 & V3A & & 3 & Single & 0.0002 & $\begin{array}{l}\text { (V3A) Have you had any cramping/contractions since last study } \\
\text { visit? }\end{array}$ \\
\hline V3AD03 & V3A & & 3 & Multi & 0.0009 & $\begin{array}{l}\text { (V3A) Since last study visit, have you had vaginal bleeding more } \\
\text { than spotting? }\end{array}$ \\
\hline V3AD04 & V3A & & 3 & Mode & 0.0007 & $\begin{array}{l}\text { (V3A) In the last } 12 \text { hours, for how many hours have you felt } \\
\text { nauseated? }\end{array}$ \\
\hline V3AD05 & V3A & & 3 & Mode & 0.0007 & $\begin{array}{l}\text { (V3A) In the last } 12 \text { hours, how many times have you vomited? } \\
\text { (V3A) In the last } 12 \text { hours, how many times have you had }\end{array}$ \\
\hline V3AD06 & V3A & & 3 & Mode & 0.0007 & $\begin{array}{l}\text { retching or dry heaves } \\
\text { without emesis (vomiting)? }\end{array}$ \\
\hline V4AE01 & $\mathrm{V} 4 \mathrm{~A}$ & & 4 & Any & 0.0001 & $\begin{array}{l}\text { (V4A) Did you have any 'flu-like illnesses,' 'really bad colds,' } \\
\text { fever, a rash, or any } \\
\text { muscle or joint aches between date of }\end{array}$ \\
\hline
\end{tabular}


medRxiv preprint doi: https://doi.org/10.1101/2021.08.24.21262142; this version posted August 26, 2021. The copyright holder for this preprint (which was not certified by peer review) is the author/funder, who has granted medRxiv a license to display the preprint in perpetuity.

\section{It is made available under a CC-BY-NC-ND 4.0 International license .}

\begin{tabular}{|c|c|c|c|c|c|c|}
\hline NAME & FILE & RULE & TEMPORAL & IMPUTE & MISSINGNESS & DESCRIPTION \\
\hline V1B_Resting_BP_Sys & V1B & Mean & 1 & Mean & & \\
\hline V1BA06a1 & V1B & & & & 0.0092 & (V1B) Resting blood pressure - Systolic (mm Hg) measure 1 \\
\hline V1BA06a2 & V1B & & & & 0.9749 & (V1B) Resting blood pressure - Systolic ( $\mathrm{mm} \mathrm{Hg}$ ) measure 2 \\
\hline V1B_Resting_BP_Dia & V1B & Mean & 1 & Mean & & \\
\hline V1BA06b1 & V1B & & & & 0.0092 & (V1B) Resting blood pressure - Diastolic (mm Hg) measure 1 \\
\hline V1BA06b2 & V1B & & & & 0.9749 & (V1B) Resting blood pressure - Diastolic $(\mathrm{mm} \mathrm{Hg})$ measure 2 \\
\hline V1B_Neck_Circ & V1B & Mean & 1 & Mean & & \\
\hline V1BA07a & V1B & & & & 0.1392 & (V1B) Neck circumference - Measure $1(\mathrm{~cm})$ \\
\hline V1BA07b & V1B & & & & 0.1442 & (V1B) Neck circumference - Measure $2(\mathrm{~cm})$ \\
\hline V1BA07c & V1B & & & & 0.9924 & (V1B) Neck circumference - Measure $3(\mathrm{~cm})$ \\
\hline V2B_Weight_lbs & V2B & Mean & 2 & Mean & & \\
\hline V2BA01_KG & V2B & & & & 0.8669 & (V2B) Weight - kg \\
\hline V2BA01_LB & $\mathrm{V} 2 \mathrm{~B}$ & & & & 0.1361 & (V2B) Weight - lbs \\
\hline V2B_Resting_BP_Sys & V2B & Mean & 2 & Mean & & \\
\hline V2BA02a1 & V2B & & & & 0.006 & (V2B) Resting blood pressure - Systolic measure 1 ( $\mathrm{mmHg})$ \\
\hline V2BA02a2 & $\mathrm{V} 2 \mathrm{~B}$ & & & & 0.9806 & (V2B) Resting blood pressure - Systolic measure $2(\mathrm{mmHg})$ \\
\hline V2B_Resting_BP_Dia & V2B & Mean & 2 & Mean & & \\
\hline V2BA02b1 & V2B & & & & 0.006 & (V2B) Resting blood pressure - Diastolic measure 1 (mmHg) \\
\hline V2BA02b2 & $\mathrm{V} 2 \mathrm{~B}$ & & & & 0.9808 & (V2B) Resting blood pressure - Diastolic measure 2 ( $\mathrm{mmHg}$ ) \\
\hline V3B_Weight_lbs & V3B & Weight & 3 & Mean & & \\
\hline V3BA01_KG & V3B & & & & 0.8675 & (V3B) Weight - kg \\
\hline V3BA01_LB & V3B & & & & 0.1352 & (V3B) Weight - lbs \\
\hline V3B_Resting_BP_Sys & V3B & Mean & 3 & Mean & & \\
\hline V3BA02a1 & V3B & & & & 0.0052 & (V3B) Resting blood pressure - Systolic measure 1 (mmHg) \\
\hline V3BA02a2 & V3B & & & & 0.9763 & (V3B) Resting blood pressure - Systolic measure $2(\mathrm{mmHg})$ \\
\hline V3B_Resting_BP_Dia & V3B & Mean & 3 & Mean & & \\
\hline V3BA02b1 & V3B & & & & 0.0052 & (V3B) Resting blood pressure - Diastolic measure 1 (mmHg) \\
\hline V3BA02b2 & V3B & & & & 0.9763 & (V3B) Resting blood pressure - Diastolic measure $2(\mathrm{mmHg})$ \\
\hline $\begin{array}{l}\text { CMA_Weight_Pre } \\
\text { Delivery_lbs }\end{array}$ & CMA & Weight & 4 & Mean & & \\
\hline CMAB01a1 & CMA & & & & 0.5736 & (CMA) Participant's last weight prior to delivery - kilograms \\
\hline CMAB01a2 & CMA & & & & 0.4468 & (CMA) Participant's last weight prior to delivery - pounds \\
\hline $\begin{array}{l}\text { CMB_Max_Admission_ } \\
\text { Temp }\end{array}$ & $\mathrm{CMB}$ & Temp & $\begin{array}{l}\text { Date } \\
\text { Abstraction }\end{array}$ & Mean & & \\
\hline CMBC01b1 & $\mathrm{CMB}$ & & & & 0.481 & $\begin{array}{l}\text { (CMB) Maximum temperature during admission or encounter } \\
\text { - degrees Celsius, }\end{array}$ \\
\hline CMBC01b2 & $\mathrm{CMB}$ & & & & 0.5494 & $\begin{array}{l}\text { (CMB) Maximum temperature during admission or encounter } \\
\text { - degrees Fahrenheit, }\end{array}$ \\
\hline V1B_Weight_lbs & V1B & Weight & 1 & Mean & & \\
\hline V1BA01_KG & V1B & & & & 0.8577 & (V1B) Weight - kg \\
\hline V1BA01_LB & V1B & & & & 0.1439 & (V1B) Weight - lbs \\
\hline V1B_Height & V1B & Mean & 1 & Mean & & \\
\hline V1BA02a & V1B & & & & 0.0093 & (V1B) Height - Measure $1(\mathrm{~cm})$ \\
\hline V1BA02b & V1B & & & & 0.0229 & (V1B) Height - Measure $2(\mathrm{~cm})$ \\
\hline V1BA02c & V1B & & & & 0.992 & (V1B) Height - Measure $3(\mathrm{~cm})$ \\
\hline $\begin{array}{l}\text { V1B_Natural_Waist_ } \\
\text { Circumference }\end{array}$ & V1B & Mean & 1 & Mean & & \\
\hline V1BA03a & V1B & & & & 0.0183 & (V1B) Natural waist circumference - Measure $1(\mathrm{~cm})$ \\
\hline V1BA03b & V1B & & & & 0.0233 & (V1B) Natural waist circumference - Measure $2(\mathrm{~cm})$ \\
\hline V1BA03c & V1B & & & & 0.9745 & (V1B) Natural waist circumference - Measure $3(\mathrm{~cm})$ \\
\hline V1B_Waist_Lilac_Crest & V1B & Mean & 1 & Mean & & \\
\hline V1BA04a & V1B & & & & 0.0184 & (V1B) Waist circumference over iliac crest - Measure $1(\mathrm{~cm})$ \\
\hline V1BA04b & V1B & & & & 0.0234 & (V1B) Waist circumference over iliac crest - Measure $2(\mathrm{~cm})$ \\
\hline V1BA04c & V1B & & & & 0.9721 & (V1B) Waist circumference over iliac crest - Measure $3(\mathrm{~cm})$ \\
\hline V1B_Hip_Circ & V1B & Mean & 1 & Mean & & \\
\hline V1BA04a & V1B & & & & 0.0189 & (V1B) Hip circumference - Measure $1(\mathrm{~cm})$ \\
\hline V1BA04b & V1B & & & & 0.0238 & (V1B) Hip circumference - Measure $2(\mathrm{~cm})$ \\
\hline V1BA04c & V1B & & & & 0.9768 & (V1B) Hip circumference - Measure $3(\mathrm{~cm})$ \\
\hline
\end{tabular}




\subsection{Ultrasound}

The ultrasound filtering group contains all features located within the ultrasound related files and chart abstractions. This includes fetal measurements, uterine artery analysis, adrenal gland study, noted conditions, amniotic fluid information, and more.

Total \# Features: 542

Layer 1 \# Features: 59

Layer 2 \# Features: 131

Relevant Files: CUA, CUB, S02, U02, U1C, U2A, U2B, U2C, U3A, U3B, U3C, U3D

Dropped Features: For this group, there were many excess features that were dropped (100\% missingness), for noted abnormalities. Abnormality code was the only feature used to represent fetal abnormalities. There was abundant metadata relevant only for either organizing data or populating other features and therefore redundant, which was dropped. Details for conditions were left for Layer 2, as were detailed measurements in the uterine artery.

\begin{tabular}{|c|c|c|c|c|c|c|}
\hline NAME & FILE & RULE & TEMP & IMPUTE & MISSING & DESCRIPTION \\
\hline CUAB02a2 & CUA & & 1 & 999 & 0.9855 & (CUA) Brain Abnormality - Code (a) \\
\hline CUAC02a2 & CUA & & 1 & 999 & 0.9981 & (CUA) Head/neck abnormality - Code (a) \\
\hline CUAD02a2 & CUA & & 1 & 999 & 0.9868 & (CUA) Chest abnormality - Code (a) \\
\hline CUAD02b2 & CUA & & 1 & 999 & 0.9987 & (CUA) Chest abnormality - Code (b) \\
\hline CUAD02c2 & CUA & & 1 & 999 & 0.9994 & (CUA) Chest abnormality - Code (c) \\
\hline CUAE02a2 & CUA & & 1 & 999 & 0.9779 & (CUA) Abdomen abnormality - Code (a) \\
\hline CUAE02b2 & CUA & & 1 & 999 & 0.9981 & (CUA) Abdomen abnormality - Code (b) \\
\hline CUAF02a2 & CUA & & 1 & 999 & 0.9975 & (CUA) Extremities abnormality - Code (a) \\
\hline CUAH02a2 & CUA & & 1 & 999 & 0.9924 & $\begin{array}{l}\text { (CUA) Malformation(s) not mentioned under brain, head/neck, } \\
\text { chest, abdomen, extremities or spine - Code (a) }\end{array}$ \\
\hline CUAH02b2 & CUA & & 1 & 999 & 0.9987 & $\begin{array}{l}\text { (CUA) Malformation(s) not mentioned under brain, head/neck, } \\
\text { chest, abdomen, extremities or spine - Code (b) }\end{array}$ \\
\hline CUBB01 & CUB & & 1 & 999 & 0.0008 & (CUB) Were any structural abnormalities detected? \\
\hline CUBB02a2 & CUB & & 1 & 999 & 0.9417 & (CUB) Abnormality - Code (a) \\
\hline CUBB02b2 & CUB & & 1 & 999 & 0.9935 & (CUB) Abnormality - Code (b) \\
\hline CUBB02c2 & CUB & & 1 & 999 & 0.9974 & (CUB) Abnormality - Code (c) \\
\hline CUBB02d2 & CUB & & 1 & 999 & 0.9987 & (CUB) Abnormality - Code (d) \\
\hline CUBB02e2 & CUB & & 1 & 999 & 0.9992 & (CUB) Abnormality - Code (e) \\
\hline CUBB02f2 & CUB & & 1 & 999 & 0.9997 & (CUB) Abnormality - Code (f) \\
\hline U1CB02 & $\mathrm{U} 1 \mathrm{C}$ & & 1 & ANY & 0.0014 & (U1C) Disclosable condition \\
\hline $\mathrm{U} 1 \mathrm{CB} 04 \mathrm{c}$ & $\mathrm{U} 1 \mathrm{C}$ & & 1 & 999 & 0.9971 & $\begin{array}{l}\text { (U1C) Disclosable condition reported - Incidental detection of } \\
\text { complete or partial placenta previa or vasa previa }\end{array}$ \\
\hline $\mathrm{U} 1 \mathrm{CC} 04$ & $\mathrm{U} 1 \mathrm{C}$ & & 1 & MEAN & 0.0287 & (U1C) Left Uterine Artery - Peak Systolic Velocity (PSV) (cm/sec) \\
\hline $\mathrm{U} 1 \mathrm{CC} 05$ & $\mathrm{U} 1 \mathrm{C}$ & & 1 & MEAN & 0.0337 & (U1C) Left Uterine Artery - Systolic/Diastolic Ratio (S/D) \\
\hline $\mathrm{U} 1 \mathrm{CC} 06$ & $\mathrm{U} 1 \mathrm{C}$ & & 1 & MEAN & 0.0294 & (U1C) Left Uterine Artery - Resistance Index (RI) \\
\hline $\mathrm{U} 1 \mathrm{CC} 07$ & U1C & & 1 & MEAN & 0.0309 & (U1C) Left Uterine Artery - Pulsatility Index (PI) \\
\hline U1CC09 & $\mathrm{U} 1 \mathrm{C}$ & & 1 & 999 & 0.0266 & (U1C) Left Uterine Artery - Early diastolic notch present \\
\hline $\mathrm{U} 1 \mathrm{CC} 12$ & $\mathrm{U} 1 \mathrm{C}$ & & 1 & 999 & 0.023 & (U1C) Left Uterine Artery - Systolic notch present \\
\hline U1CD04 & $\mathrm{U} 1 \mathrm{C}$ & & 1 & MEAN & 0.0345 & (U1C) Right Uterine Artery - Peak Systolic Velocity (PSV) $(\mathrm{cm} / \mathrm{sec})$ \\
\hline U1CD05 & $\mathrm{U} 1 \mathrm{C}$ & & 1 & MEAN & 0.0402 & (U1C) Right Uterine Artery - Systolic/Diastolic Ratio (S/D) \\
\hline $\mathrm{U} 1 \mathrm{CD} 06$ & $\mathrm{U} 1 \mathrm{C}$ & & 1 & MEAN & 0.0345 & (U1C) Right Uterine Artery - Resistance Index (RI) \\
\hline U1CD07 & $\mathrm{U} 1 \mathrm{C}$ & & 1 & MEAN & 0.0359 & (U1C) Right Uterine Artery - Pulsatility Index (PI) \\
\hline U1CD09 & $\mathrm{U} 1 \mathrm{C}$ & & 1 & 999 & 0.0302 & (U1C) Right Uterine Artery - Early diastolic notch present \\
\hline U1CD12 & $\mathrm{U} 1 \mathrm{C}$ & & 1 & 999 & 0.0294 & (U1C) Right Uterine Artery - Systolic notch present \\
\hline U2AB02 & $\mathrm{U} 2 \mathrm{~A}$ & & 2 & MEAN & 0.0113 & (U2A) Biparietal Diameter - cm \\
\hline U2AB03 & $\mathrm{U} 2 \mathrm{~A}$ & & 2 & MEAN & 0.011 & (U2A) Head Circumference - cm \\
\hline U2AB04 & $\mathrm{U} 2 \mathrm{~A}$ & & 2 & MEAN & 0.0115 & (U2A) Abdominal Circumference - $\mathrm{cm}$ \\
\hline U2AB05 & $\mathrm{U} 2 \mathrm{~A}$ & & 2 & MEAN & 0.0106 & (U2A) Femur Diaphysis Length - cm \\
\hline $\mathrm{U} 2 \mathrm{AB} 06$ & $\mathrm{U} 2 \mathrm{~A}$ & & 2 & MEAN & 0.1167 & (U2A) Estimated fetal weight as reported - grams \\
\hline U2AB07 & $\mathrm{U} 2 \mathrm{~A}$ & & 2 & $\mathrm{~N} / \mathrm{A}$ & 0.595 & (U2A) Estimated fetal weight percentile as reported - percentile \\
\hline $\mathrm{U} 2 \mathrm{AC} 01$ & $\mathrm{U} 2 \mathrm{~A}$ & & 2 & $\mathrm{ANY}$ & 0.4733 & (U2A) Disclosable condition \\
\hline $\mathrm{U} 2 \mathrm{AC} 03 \mathrm{c}$ & $\mathrm{U} 2 \mathrm{~A}$ & & 2 & 999 & 0.9871 & $\begin{array}{l}\text { (U2A) Disclosable condition reported - Incidental finding of } \\
\text { oligohydramnios }\end{array}$ \\
\hline $\mathrm{U} 2 \mathrm{AC} 03 \mathrm{e}$ & $\mathrm{U} 2 \mathrm{~A}$ & & 2 & 999 & 0.9871 & $\begin{array}{l}\text { (U2A) Disclosable condition reported - Incidental detection of } \\
\text { complete or partial placenta previa or vasa previa }\end{array}$ \\
\hline U2BB02 & $\mathrm{U} 2 \mathrm{~B}$ & & 2 & NEG1 & 0.0208 & (U2B) Cervical length - mm \\
\hline U2BB03 & $\mathrm{U} 2 \mathrm{~B}$ & & 2 & 999 & 0.0051 & (U2B) Funnel \\
\hline U2BB04 & $\mathrm{U} 2 \mathrm{~B}$ & & 2 & NEG1 & 0.9944 & (U2B) Funnel length - mm \\
\hline $\mathrm{U} 2 \mathrm{BB} 05$ & $\mathrm{U} 2 \mathrm{~B}$ & & 2 & 999 & 0.0059 & (U2B) Debris \\
\hline
\end{tabular}




\begin{tabular}{|c|c|c|c|c|c|c|}
\hline NAME & FILE & RULE & TEMP & IMPUTE & MISSING & DESCRIPTION \\
\hline U2BC01 & U2B & & 2 & ANY & 0.1082 & (U2B) Disclosable condition \\
\hline U2BC03d & $\mathrm{U} 2 \mathrm{~B}$ & & 2 & 999 & 0.9815 & $\begin{array}{l}\text { (U2B) Disclosable condition reported - Incidental detection of } \\
\text { complete or partial placenta previa or vasa previa }\end{array}$ \\
\hline $\mathrm{U} 2 \mathrm{CB} 03$ & $\mathrm{U} 2 \mathrm{C}$ & & 2 & ANY & 0 & (U2C) Disclosable condition reported \\
\hline $\mathrm{U} 2 \mathrm{CB} 04 \mathrm{c}$ & $\mathrm{U} 2 \mathrm{C}$ & & 2 & 999 & 0.9825 & $\begin{array}{l}\text { (U2C) Disclosable condition reported - Incidental detection of } \\
\text { complete or partial placenta previa or vasa previa }\end{array}$ \\
\hline $\mathrm{U} 2 \mathrm{CC} 04$ & $\mathrm{U} 2 \mathrm{C}$ & & 2 & MEAN & 0.0167 & (U2C) Left Uterine Artery - Peak Systolic Velocity (PSV) (cm/sec) \\
\hline $\mathrm{U} 2 \mathrm{CC} 05$ & $\mathrm{U} 2 \mathrm{C}$ & & 2 & MEAN & 0.0191 & (U2C) Left Uterine Artery - Systolic/Diastolic Ratio (S/D) \\
\hline $\mathrm{U} 2 \mathrm{CC} 06$ & $\mathrm{U} 2 \mathrm{C}$ & & 2 & MEAN & 0.0171 & (U2C) Left Uterine Artery - Resistance Index (RI) \\
\hline $\mathrm{U} 2 \mathrm{CC} 07$ & $\mathrm{U} 2 \mathrm{C}$ & & 2 & MEAN & 0.0188 & (U2C) Left Uterine Artery - Pulsatility Index (PI) \\
\hline U2CC09 & $\mathrm{U} 2 \mathrm{C}$ & & 2 & 999 & 0.0146 & (U2C) Left Uterine Artery - Early diastolic notch present \\
\hline $\mathrm{U} 2 \mathrm{CC} 12$ & $\mathrm{U} 2 \mathrm{C}$ & & 2 & 999 & 0.016 & (U2C) Left Uterine Artery - Systolic notch present \\
\hline $\mathrm{U} 2 \mathrm{CD} 04$ & $\mathrm{U} 2 \mathrm{C}$ & & 2 & MEAN & 0.0151 & (U2C) Right Uterine Artery - Peak Systolic Velocity (PSV) $(\mathrm{cm} / \mathrm{sec})$ \\
\hline $\mathrm{U} 2 \mathrm{CD} 05$ & $\mathrm{U} 2 \mathrm{C}$ & & 2 & MEAN & 0.0182 & (U2C) Right Uterine Artery - Systolic/Diastolic Ratio (S/D) \\
\hline U2CD06 & $\mathrm{U} 2 \mathrm{C}$ & & 2 & MEAN & 0.0151 & (U2C) Right Uterine Artery - Resistance Index (RI) \\
\hline $\mathrm{U} 2 \mathrm{CD} 07$ & $\mathrm{U} 2 \mathrm{C}$ & & 2 & MEAN & 0.0164 & (U2C) Right Uterine Artery - Pulsatility Index (PI) \\
\hline U2CD09 & $\mathrm{U} 2 \mathrm{C}$ & & 2 & 999 & 0.0131 & (U2C) Right Uterine Artery - Early diastolic notch present \\
\hline $\mathrm{U} 2 \mathrm{CD} 12$ & $\mathrm{U} 2 \mathrm{C}$ & & 2 & 999 & 0.0148 & (U2C) Right Uterine Artery - Systolic notch present \\
\hline U3AB02 & $\mathrm{U} 3 \mathrm{~A}$ & & 3 & MEAN & 0.0077 & (U3A) Biparietal Diameter $(\mathrm{cm})$ \\
\hline U3AB03 & U3A & & 3 & MEAN & 0.0076 & (U3A) Head Circumference (cm) \\
\hline $\mathrm{U} 3 \mathrm{AB} 04$ & $\mathrm{U} 3 \mathrm{~A}$ & & 3 & MEAN & 0.0064 & (U3A) Abdominal Circumference (cm) \\
\hline U3AB05 & U3A & & 3 & MEAN & 0.0068 & (U3A) Femur Diaphysis Length $(\mathrm{cm})$ \\
\hline U3AB07 & $\mathrm{U} 3 \mathrm{~A}$ & & 3 & MEAN & 0.0127 & (U3A) Estimated fetal weight as reported - grams \\
\hline U3AC01 & $\mathrm{U} 3 \mathrm{~A}$ & & 3 & ANY & 0.0437 & (U3A) Disclosable condition \\
\hline $\mathrm{U} 3 \mathrm{AC} 03 \mathrm{c}$ & $\mathrm{U} 3 \mathrm{~A}$ & & 3 & SUM_LEQ & 0.9915 & $\begin{array}{l}\text { (U3A) Disclosable condition reported - Oligohydramnios } \\
\text { (maximal vertical pocket of }<2 \mathrm{~cm} \text { or AFI }<5 \mathrm{~cm} \text { ) }\end{array}$ \\
\hline U3AC03e & $\mathrm{U} 3 \mathrm{~A}$ & & 3 & 999 & 0.9915 & $\begin{array}{l}\text { (U3A) Disclosable condition reported - Incidental detection of } \\
\text { complete or partial placenta previa or vasa previa }\end{array}$ \\
\hline U3BB02 & $\mathrm{U} 3 \mathrm{~B}$ & & 3 & NEG1 & 0.0152 & (U3B) Cervical length - mm \\
\hline U3BB03 & $\mathrm{U} 3 \mathrm{~B}$ & & 3 & 999 & 0.0052 & (U3B) Funnel \\
\hline U3BB04 & $\mathrm{U} 3 \mathrm{~B}$ & & 3 & NEG1 & 0.9799 & (U3B) Funnel length - mm \\
\hline U3BB05 & $\mathrm{U} 3 \mathrm{~B}$ & & 3 & 999 & 0.0064 & (U3B) Debris \\
\hline U3BC01 & U3B & & 3 & ANY & 0.0122 & (U3B) Disclosable condition \\
\hline U3BC03d & $\mathrm{U} 3 \mathrm{~B}$ & & 3 & 999 & 0.984 & $\begin{array}{l}\text { (U3B) Disclosable condition reported - Incidental detection of } \\
\text { complete or partial placenta previa or vasa previa }\end{array}$ \\
\hline U3CB02 & $\mathrm{U} 3 \mathrm{C}$ & & 3 & ANY & 0.0009 & (U3C) Disclosable condition \\
\hline $\mathrm{U} 3 \mathrm{CB} 04 \mathrm{c}$ & $\mathrm{U} 3 \mathrm{C}$ & & 3 & 999 & 0.9954 & $\begin{array}{l}\text { (U3C) Disclosable condition reported - Incidental detection of } \\
\text { complete or partial placenta previa or vasa previa }\end{array}$ \\
\hline $\mathrm{U} 3 \mathrm{CC} 04$ & $\mathrm{U} 3 \mathrm{C}$ & & 3 & MEAN & 0.0271 & (U3C) Left Uterine Artery - Peak Systolic Velocity (PSV) $(\mathrm{cm} / \mathrm{sec})$ \\
\hline $\mathrm{U} 3 \mathrm{CC} 05$ & $\mathrm{U} 3 \mathrm{C}$ & & 3 & MEAN & 0.0271 & (U3C) Left Uterine Artery - Systolic/Diastolic Ratio (S/D) \\
\hline U3CC06 & $\mathrm{U} 3 \mathrm{C}$ & & 3 & MEAN & 0.0264 & (U3C) Left Uterine Artery - Resistance Index (RI) \\
\hline $\mathrm{U} 3 \mathrm{CC} 07$ & $\mathrm{U} 3 \mathrm{C}$ & & 3 & MEAN & 0.0266 & (U3C) Left Uterine Artery - Pulsatility Index (PI) \\
\hline U3CC09 & $\mathrm{U} 3 \mathrm{C}$ & & 3 & 999 & 0.0243 & (U3C) Left Uterine Artery - Early diastolic notch present \\
\hline $\mathrm{U} 3 \mathrm{CC} 12$ & $\mathrm{U} 3 \mathrm{C}$ & & 3 & 999 & 0.0254 & (U3C) Left Uterine Artery - Systolic notch present \\
\hline U3CD04 & $\mathrm{U} 3 \mathrm{C}$ & & 3 & MEAN & 0.0259 & (U3C) Right Uterine Artery - Peak Systolic Velocity (PSV) $(\mathrm{cm} / \mathrm{sec})$ \\
\hline $\mathrm{U} 3 \mathrm{CD} 05$ & $\mathrm{U} 3 \mathrm{C}$ & & 3 & MEAN & 0.0275 & (U3C) Right Uterine Artery - Systolic/Diastolic Ratio (S/D) \\
\hline U3CD06 & $\mathrm{U} 3 \mathrm{C}$ & & 3 & MEAN & 0.0257 & (U3C) Right Uterine Artery - Resistance Index (RI) \\
\hline U3CD07 & $\mathrm{U} 3 \mathrm{C}$ & & 3 & MEAN & 0.0264 & (U3C) Right Uterine Artery - Pulsatility Index (PI) \\
\hline U3CD09 & $\mathrm{U} 3 \mathrm{C}$ & & 3 & 999 & 0.0234 & (U3C) Right Uterine Artery - Early diastolic notch present \\
\hline U3CD12 & $\mathrm{U} 3 \mathrm{C}$ & & 3 & 999 & 0.0268 & (U3C) Right Uterine Artery - Systolic notch present \\
\hline U3DC01 & $\mathrm{U} 3 \mathrm{D}$ & & 3 & 999 & 0.0677 & (U3D) Fetal adrenal gland mass \\
\hline $\mathrm{U} 3 \mathrm{DC} 02$ & $\mathrm{U} 3 \mathrm{D}$ & & 3 & 999 & 0.0004 & (U3D) Disclosable condition reported \\
\hline U3DD01 & $\mathrm{U} 3 \mathrm{D}$ & & 3 & 999 & 0.0895 & $\begin{array}{l}\text { (U3D) Fetal Adrenal Gland Measures Visit } 3 \text { - Which gland } \\
\text { was used for measurement }\end{array}$ \\
\hline Calc_Polyhydramnios & & $\begin{array}{l}\text { Calc }_{-} \\
\text {Polyhydramnios }\end{array}$ & 3 & & & \\
\hline U3AB06a & U3A & & 3 & MEAN & 0.0761 & (U3A) Amniotic Fluid Index (AFI) - Quadrant 1 (cm) \\
\hline U3AB06b & $\mathrm{U} 3 \mathrm{~A}$ & & 3 & MEAN & 0.074 & (U3A) Amniotic Fluid Index (AFI) - Quadrant $2(\mathrm{~cm})$ \\
\hline U3AB06c & $\mathrm{U} 3 \mathrm{~A}$ & & 3 & MEAN & 0.0736 & (U3A) Amniotic Fluid Index (AFI) - Quadrant $3(\mathrm{~cm})$ \\
\hline U3AB06d & U3A & & 3 & MEAN & 0.0833 & (U3A) Amniotic Fluid Index (AFI) - Quadrant $4(\mathrm{~cm})$ \\
\hline adrenal_gland_length & & adrenal_measure & 3 & & & \\
\hline U3DD02a1 & $\mathrm{U} 3 \mathrm{D}$ & & 3 & MEAN & 0.1898 & $\begin{array}{l}\text { (U3D) Adrenal Gland Measurements, } \\
\text { Adrenal gland - Length in mm (1) }\end{array}$ \\
\hline U3DD02a2 & $\mathrm{U} 3 \mathrm{D}$ & & 3 & MEAN & 0.2111 & $\begin{array}{l}\text { (U3D) Adrenal Gland Measurements, } \\
\text { Adrenal gland - Length in mm (2) }\end{array}$ \\
\hline U3DD02a3 & $\mathrm{U} 3 \mathrm{D}$ & & 3 & MEAN & 0.257 & $\begin{array}{l}\text { (U3D) Adrenal Gland Measurements, } \\
\text { Adrenal gland - Length in mm (3) }\end{array}$ \\
\hline U3DD02a1 & $\mathrm{U} 3 \mathrm{D}$ & & 3 & MEAN & 0.9951 & $\begin{array}{l}\text { (U3D) Repeat Adrenal Gland Measurements, } \\
\text { Adrenal gland length in mm, Measure } 1\end{array}$ \\
\hline U3DF02a2 & $\mathrm{U} 3 \mathrm{D}$ & & 3 & MEAN & 0.9955 & $\begin{array}{l}\text { (U3D) Repeat Adrenal Gland Measurements, } \\
\text { Adrenal gland length in mm, Measure } 2\end{array}$ \\
\hline U3DF02a3 & U3D & & 3 & MEAN & 0.9955 & $\begin{array}{l}\text { (U3D) Repeat Adrenal Gland Measurements, } \\
\text { Adrenal gland length in mm, Measure } 3\end{array}$ \\
\hline U3DD05 & U3D & & 3 & $\mathrm{~N} / \mathrm{A}$ & 0.0579 & $\begin{array}{l}\text { (U3D) Fetal Adrenal Gland Measures Visit } 3 \text { - } \\
\text { Adrenal Glad measurements exam complete }\end{array}$ \\
\hline U3DF05 & $\mathrm{U} 3 \mathrm{D}$ & & 3 & $\mathrm{~N} / \mathrm{A}$ & 0.9933 & $\begin{array}{l}\text { (U3D) Repeat Adrenal Gland Measurements - } \\
\text { Exam complete }\end{array}$ \\
\hline
\end{tabular}


medRxiv preprint doi: https://doi.org/10.1101/2021.08.24.21262142; this version posted August 26, 2021. The copyright holder for this preprint (which was not certified by peer review) is the author/funder, who has granted medRxiv a license to display the preprint in perpetuity.

It is made available under a CC-BY-NC-ND 4.0 International license .

\begin{tabular}{|c|c|c|c|c|c|c|}
\hline NAME & FILE & RULE & TEMP & IMPUTE & MISSING & DESCRIPTION \\
\hline fetal_zone_length & & adrenal_measure & 3 & & & \multirow{9}{*}{$\begin{array}{l}\text { (U3D) Adrenal Gland Measurements, } \\
\text { Fetal zone - Length in mm (1) } \\
\text { (U3D) Adrenal Gland Measurements, } \\
\text { Fetal zone - Length in mm (2) } \\
\text { (U3D) Adrenal Gland Measurements, } \\
\text { Fetal zone - Length in mm (3) } \\
\text { (U3D) Repeat Adrenal Gland Measurements, } \\
\text { Fetal zone length in mm, Measure } 1 \\
\text { (U3D) Repeat Adrenal Gland Measurements, } \\
\text { Fetal zone length in mm, Measure } 2 \\
\text { (U3D) Repeat Adrenal Gland Measurements, } \\
\text { Fetal zone length in mm, Measure } 3 \\
\text { (U3D) Fetal Adrenal Gland Measures Visit } 3 \\
\text { Adrenal Glad measurements exam complete } \\
\text { (U3D) Repeat Adrenal Gland Measurements - } \\
\text { Exam complete }\end{array}$} \\
\hline U3DD02b1 & $\mathrm{U} 3 \mathrm{D}$ & & 3 & MEAN & 0.1906 & \\
\hline U3DD02b2 & U3D & & 3 & MEAN & 0.212 & \\
\hline U3DD02b3 & U3D & & 3 & MEAN & 0.2584 & \\
\hline $\mathrm{U} 3 \mathrm{DF} 02 \mathrm{~b} 1$ & $\mathrm{U} 3 \mathrm{D}$ & & 3 & MEAN & 0.9951 & \\
\hline $\mathrm{U} 3 \mathrm{DF} 02 \mathrm{~b} 2$ & U3D & & 3 & MEAN & 0.9955 & \\
\hline U3DF02b3 & U3D & & 3 & MEAN & 0.9955 & \\
\hline U3DD05 & U3D & & 3 & $\mathrm{~N} / \mathrm{A}$ & 0.0579 & \\
\hline U3DF05 & U3D & & 3 & $\mathrm{~N} / \mathrm{A}$ & 0.9933 & \\
\hline adrenal_gland_width & & adrenal_measure & 3 & & & \multirow{9}{*}{$\begin{array}{l}\text { (U3D) Adrenal Gland Measurements, } \\
\text { Adrenal gland - Width in mm (1) } \\
\text { (U3D) Adrenal Gland Measurements, } \\
\text { Adrenal gland - Width in mm (2) } \\
\text { (U3D) Adrenal Gland Measurements, } \\
\text { Adrenal gland - Width in mm (3) } \\
\text { (U3D) Repeat Adrenal Gland Measurements, } \\
\text { Adrenal gland length in mm, Measure } 1 \\
\text { (U3D) Repeat Adrenal Gland Measurements, } \\
\text { Adrenal gland length in mm, Measure } 2 \\
\text { (U3D) Repeat Adrenal Gland Measurements, } \\
\text { Adrenal gland length in mm, Measure } 3 \\
\text { (U3D) Fetal Adrenal Gland Measures Visit } 3 \text { - } \\
\text { Adrenal Glad measurements exam complete } \\
\text { (U3D) Repeat Adrenal Gland Measurements - } \\
\text { Exam complete }\end{array}$} \\
\hline U3DD03a1 & U3D & & 3 & MEAN & 0.1929 & \\
\hline U3DD03a2 & U3D & & 3 & MEAN & 0.2134 & \\
\hline U3DD03a3 & U3D & & 3 & MEAN & 0.2615 & \\
\hline U3DF03a1 & $\mathrm{U} 3 \mathrm{D}$ & & 3 & MEAN & 0.9951 & \\
\hline U3DF03a2 & U3D & & 3 & MEAN & 0.9955 & \\
\hline U3DF03a3 & U3D & & 3 & MEAN & 0.9955 & \\
\hline U3DD05 & U3D & & 3 & $\mathrm{~N} / \mathrm{A}$ & 0.0579 & \\
\hline U3DF05 & U3D & & 3 & $\mathrm{~N} / \mathrm{A}$ & 0.9933 & \\
\hline fetal_zone_width & & adrenal_measure & 3 & & & \multirow{9}{*}{$\begin{array}{l}\text { (U3D) Adrenal Gland Measurements, } \\
\text { Fetal zone - Width in mm (1) } \\
\text { (U3D) Adrenal Gland Measurements, } \\
\text { Fetal zone - Width in mm (2) } \\
\text { (U3D) Adrenal Gland Measurements, } \\
\text { Fetal zone - Width in mm (3) } \\
\text { (U3D) Repeat Adrenal Gland Measurements, } \\
\text { Fetal zone width in mm, Measure } 1 \\
\text { (U3D) Repeat Adrenal Gland Measurements, } \\
\text { Fetal zone width in mm, Measure } 2 \\
\text { (U3D) Repeat Adrenal Gland Measurements, } \\
\text { Fetal zone width in mm, Measure } 3 \\
\text { (U3D) Fetal Adrenal Gland Measures Visit } 3 \text { - } \\
\text { Adrenal Glad measurements exam complete } \\
\text { (U3D) Repeat Adrenal Gland Measurements - } \\
\text { Exam complete }\end{array}$} \\
\hline U3DD03b1 & U3D & & 3 & MEAN & 0.1929 & \\
\hline U3DD03b2 & U3D & & 3 & MEAN & 0.2143 & \\
\hline U3DD03b3 & U3D & & 3 & MEAN & 0.2633 & \\
\hline U3DF03b1 & U3D & & 3 & MEAN & 0.9951 & \\
\hline U3DF03b2 & U3D & & 3 & MEAN & 0.9955 & \\
\hline U3DF03b3 & U3D & & 3 & MEAN & 0.9955 & \\
\hline U3DD05 & $\mathrm{U} 3 \mathrm{D}$ & & 3 & $\mathrm{~N} / \mathrm{A}$ & 0.0579 & \\
\hline U3DF05 & U3D & & 3 & $\mathrm{~N} / \mathrm{A}$ & 0.9933 & \\
\hline
\end{tabular}


medRxiv preprint doi: https://doi.org/10.1101/2021.08.24.21262142; this version posted August 26, 2021. The copyright holder for this preprint (which was not certified by peer review) is the author/funder, who has granted medRxiv a license to display the preprint in perpetuity.

It is made available under a CC-BY-NC-ND 4.0 International license.

\begin{tabular}{|c|c|c|c|c|c|c|}
\hline NAME & FILE & RULE & TEMP & IMPUTE & MISSING & DESCRIPTION \\
\hline adrenal_gland_depth & & adrenal_measure & 3 & & & \\
\hline U3DD04a1 & U3D & & 3 & MEAN & 0.7657 & \multirow{8}{*}{$\begin{array}{l}\text { (U3D) Adrenal Gland Measurements, } \\
\text { Adrenal gland - Depth in mm (1) } \\
\text { (U3D) Adrenal Gland Measurements, } \\
\text { Adrenal gland - Depth in mm (2) } \\
\text { (U3D) Adrenal Gland Measurements, } \\
\text { Adrenal gland - Depth in mm (3) } \\
\text { (U3D) Repeat Adrenal Gland Measurements, } \\
\text { Adrenal gland depth in mm, Measure } 1 \\
\text { (U3D) Repeat Adrenal Gland Measurements, } \\
\text { Adrenal gland depth in mm, Measure } 2 \\
\text { (U3D) Repeat Adrenal Gland Measurements, } \\
\text { Adrenal gland depth in mm, Measure } 3 \\
\text { (U3D) Fetal Adrenal Gland Measures Visit } 3 \text { - } \\
\text { Adrenal Glad measurements exam complete } \\
\text { (U3D) Repeat Adrenal Gland Measurements - } \\
\text { Exam complete }\end{array}$} \\
\hline U3DD04a2 & U3D & & 3 & MEAN & 0.7679 & \\
\hline U3DD04a3 & U3D & & 3 & MEAN & 0.7719 & \\
\hline U3DF04a1 & U3D & & 3 & MEAN & 0.9982 & \\
\hline U3DF04a2 & U3D & & 3 & MEAN & 0.9982 & \\
\hline U3DF04a3 & U3D & & 3 & MEAN & 0.9982 & \\
\hline U3DD05 & U3D & & 3 & $\mathrm{~N} / \mathrm{A}$ & 0.0579 & \\
\hline U3DF05 & U3D & & 3 & $\mathrm{~N} / \mathrm{A}$ & 0.9933 & \\
\hline fetal_zone_depth & & adrenal_measure & 3 & & & \multirow{9}{*}{$\begin{array}{l}\text { (U3D) Adrenal Gland Measurements, } \\
\text { Fetal zone - Depth in mm (1) } \\
\text { (U3D) Adrenal Gland Measurements, } \\
\text { Fetal zone - Depth in mm (2) } \\
\text { (U3D) Adrenal Gland Measurements, } \\
\text { Fetal zone - Depth in mm (3) } \\
\text { (U3D) Repeat Adrenal Gland Measurements, } \\
\text { Fetal zone, depth in mm, Measure } 1 \\
\text { (U3D) Repeat Adrenal Gland Measurements, } \\
\text { Fetal zone, depth in mm, Measure } 2 \\
\text { (U3D) Repeat Adrenal Gland Measurements, } \\
\text { Fetal zone, depth in mm, Measure } 3 \\
\text { (U3D) Fetal Adrenal Gland Measures Visit } 3 \\
\text { Adrenal Glad measurements exam complete } \\
\text { (U3D) Repeat Adrenal Gland Measurements - } \\
\text { Exam complete }\end{array}$} \\
\hline U3DD04b1 & U3D & & 3 & MEAN & 0.7657 & \\
\hline U3DD04b2 & U3D & & 3 & MEAN & 0.7679 & \\
\hline U3DD04b3 & $\mathrm{U} 3 \mathrm{D}$ & & 3 & MEAN & 0.7719 & \\
\hline U3DF04b1 & U3D & & 3 & MEAN & 0.9982 & \\
\hline U3DF04b2 & U3D & & 3 & MEAN & 0.9982 & \\
\hline U3DF04b3 & U3D & & 3 & MEAN & 0.9982 & \\
\hline U3DD05 & U3D & & 3 & $\mathrm{~N} / \mathrm{A}$ & 0.0579 & \\
\hline U3DF05 & $\mathrm{U} 3 \mathrm{D}$ & & 3 & $\mathrm{~N} / \mathrm{A}$ & 0.9933 & \\
\hline
\end{tabular}


medRxiv preprint doi: https://doi.org/10.1101/2021.08.24.21262142; this version posted August 26, 2021. The copyright holder for this preprint (which was not certified by peer review) is the author/funder, who has granted medRxiv a license to display the preprint in perpetuity.

It is made available under a CC-BY-NC-ND 4.0 International license .

\subsection{Medical History}

The medical history filtering includes questions regarding the current or recent (prenatal labs) medical conditions of the patient, which is a quite large category. As a result, using literature review and clinician input, we narrowed down our relevant features to PTB-related factors like STI screens, gynecological infections, and diabetes/hypertension data. Aside from diagnostics, we also included prior information about previous pregnancy loss history, given the trial's focus on nulliparous patients, as well as relevant CBC results like hematocrit levels, and patient previous procedures and pre-pregnancy weight.

Total Features: 2294

Layer 1 Features: 100

Layer 2 Features: 100

Relevant Files: CLA, CLB, CMA, CMB, CMD, CME, S02, V1A, VXX, demographics (ancillary), pregnancy_outcomes (ancillary)

Dropped Features: For this group, we dropped most features due to a large amount of information. As a result, we focused on health conditions that pertained most to PTB risk factors.

Table 9: Medical History Filtering

\begin{tabular}{|c|c|c|c|c|c|c|}
\hline NAME & FILE & RULE & TEMPORAL & IMPUTE & MISSING & DESCRIPTION \\
\hline CLAA01a & CLA & & 1 & Mean & 0.035 & $\begin{array}{l}\text { (CLA) Complete blood count - } \\
\text { Hemoglobin } \mathrm{g} / \mathrm{dL}\end{array}$ \\
\hline CLAA01b & CLA & & 1 & Mean & 0.0376 & $\begin{array}{l}\text { (CLA) Complete blood count - } \\
\text { Hematocrit } \%\end{array}$ \\
\hline CLAA01d & CLA & & 1 & Mean & 0.0945 & $\begin{array}{l}\text { (CLA) Complete blood count - Platelet count } \\
\text { x10 } 3 / \mathrm{mm} 3(\mathrm{x} 103 \mathrm{~L})\end{array}$ \\
\hline CLAA06a2 & CLA & & 1 & Onehot & 0.8675 & (CLA) Urine culture - Organism code (a) \\
\hline CLAA06b2 & CLA & & 1 & Onehot & 0.9912 & (CLA) Urine culture - Organism code (b) \\
\hline CLAA07 & CLA & & 1 & Onehot & 0.1827 & (CLA) Gonorrheal screen \\
\hline CLAA08 & CLA & & 1 & Onehot & 0.1751 & (CLA) Chlamydial screen \\
\hline CLAA09 & CLA & & 1 & Onehot & 0.0535 & (CLA) VDRL/RPR (syphilis) test \\
\hline CLAB02d2 & CLA & & 1 & Mean & 0.5419 & $\begin{array}{l}\text { (CLA) First trimester serum screen PAPP-A } \\
\text { Results - Multiples of the median (MoM) }\end{array}$ \\
\hline CLAB02e2 & CLA & & 1 & Mean & 0.5616 & $\begin{array}{l}\text { (CLA) First trimester serum screen beta HCG } \\
\text { - Multiples of the median (MoM) }\end{array}$ \\
\hline CLAC01c2 & CLA & & 2 & Mean & 0.6079 & $\begin{array}{l}\text { (CLA) Second trimester screen AFP Results - } \\
\text { Multiples of the median (MoM) }\end{array}$ \\
\hline CLAC01d2 & CLA & & 2 & Mean & 0.6848 & $\begin{array}{l}\text { (CLA) Second trimester screen Total beta } \\
\text { HCG Results - Multiples of the median (MoM) }\end{array}$ \\
\hline CLAC01e2 & CLA & & 2 & Mean & 0.6831 & $\begin{array}{l}\text { (CLA) Second trimester screen uEstriol } \\
\text { Results - Multiples of the median (MoM) }\end{array}$ \\
\hline CLAC01f2 & CLA & & 2 & Mean & 0.6867 & $\begin{array}{l}\text { (CLA) Inhibin A (DIA) Results - Multiples of } \\
\text { the median (MoM) }\end{array}$ \\
\hline CLAD01a2 & CLA & & 3 & Mean & 0.1797 & $\begin{array}{l}\text { (CLA) Third Trimester Lab Studies } \\
\text { (>24 } 0 \text { weeks) Blood count, Lowest hemoglobin } \\
\text { during third trimester before labor }\end{array}$ \\
\hline CLAD01b2 & CLA & & 3 & Mean & 0.2049 & $\begin{array}{l}\text { (CLA) Lowest hematocrit during third trimester } \\
\text { before labor and delivery - Result } \%\end{array}$ \\
\hline CLAD02a & CLA & & 3 & Onehot & 0.7854 & (CLA) Last third trimester urine culture - result \\
\hline CLAD02a1b & CLA & & 3 & Onehot & 0.9561 & $\begin{array}{l}\text { (CLA) Last third trimester urine culture - } \\
\text { Organism code (1) }\end{array}$ \\
\hline CLAD02a2b & CLA & & 3 & Onehot & 0.9962 & $\begin{array}{l}\text { (CLA) Last third trimester urine culture - } \\
\text { Organism code }(2)\end{array}$ \\
\hline CLAD03a & CLA & & 3 & Onehot & 0.7255 & $\begin{array}{l}\text { (CLA) Last third trimester Gonorrheal screen - } \\
\text { Result }\end{array}$ \\
\hline CLAD04a & CLA & & 3 & Onehot & 0.7268 & $\begin{array}{l}\text { (CLA) Last third trimester Chlamydial screen - } \\
\text { result }\end{array}$ \\
\hline CLAD05a & CLA & & 3 & Onehot & 0.6993 & $\begin{array}{l}\text { (CLA) Last third trimester VDRL/RPR } \\
\text { (syphilis) test - Result }\end{array}$ \\
\hline CLAD06a & CLA & & 3 & Onehot & 0.1277 & $\begin{array}{l}\text { (CLA) Last third trimester GBS } \\
\text { culture/test - Result }\end{array}$ \\
\hline
\end{tabular}




\begin{tabular}{|c|c|c|c|c|c|c|}
\hline NAME & FILE & RULE & TEMPORAL & IMPUTE & MISSING & DESCRIPTION \\
\hline CMAC16 & CMA & & 4 & Onehot & 0.0021 & $\begin{array}{l}\text { (CMA) Did the participant have a diagnosis } \\
\text { of chorioamnionitis documented in the chart } \\
\text { by a care giver prior to delivery }\end{array}$ \\
\hline CMAE05 & CMA & & 4 & Onehot & 0.0018 & (CMA) Abruptio placenta \\
\hline CMAE09 & CMA & & 4 & Onehot & 0.0019 & (CMA) Cerebral vascular accident (CVA) \\
\hline CMAE10 & CMA & & 4 & Onehot & 0.0018 & $\begin{array}{l}(\mathrm{CMA}) \text { SEver anemia (Hematocrit }< \\
20 \mathrm{vol} \% \text { treated with blood transfusion) }\end{array}$ \\
\hline CMAH01b3 & CMA & & 4 & Mean & 0.2241 & $\begin{array}{l}\text { (CMA) Results of complete blood count: } \\
\text { - Hemoglobin }(\mathrm{g} / \mathrm{dL})\end{array}$ \\
\hline CMAH01b4 & CMA & & 4 & Mean & 0.2244 & $\begin{array}{l}\text { (CMA) Results of complete blood count: } \\
\text { - Hematocrit }(\%)\end{array}$ \\
\hline CMAH01b6 & CMA & & 4 & Mean & 0.2276 & $\begin{array}{l}\text { (CMA) Results of complete blood count: } \\
\text { - Platelet count x } 10^{\wedge} 3 / \mathrm{mm}^{\wedge} 3\left(\mathrm{x} 10^{\wedge} 3 / \mathrm{L}\right)\end{array}$ \\
\hline CMAH02b & CMA & & 4 & Onehot & 0.9791 & (CMA) Gonorrhea screen test result \\
\hline CMAH03b & CMA & & 4 & Onehot & 0.9786 & (CMA) Chlamydia screen test result \\
\hline CMAH04b & CMA & & 4 & Onehot & 0.9583 & (CMA) Urine drug screen result \\
\hline CMBF01b & $\mathrm{CMB}$ & & 4 & Onehot & 0.8973 & $\begin{array}{l}\text { (CMB) Participant had a cervico-vaginal } \\
\text { fetal fibronectin sampled collected, result }\end{array}$ \\
\hline CMBG01 & $\mathrm{CMB}$ & & 4 & Onehot & 0 & (CMB) Participant had a cerclage placed \\
\hline CMBI01 & $\mathrm{CMB}$ & & 4 & Onehot & 0 & $\begin{array}{l}\text { (CMB) Did the participant receive tocolysis } \\
\text { at any time during this hospital encounter? } \\
\text { (CMB) Did the participant have an }\end{array}$ \\
\hline CMBJ01 & $\mathrm{CMB}$ & & 4 & Onehot & 0 & $\begin{array}{l}\text { infection or receive antibiotics } \\
\text { during this hospital encounter? }\end{array}$ \\
\hline CMBJ02 & $\mathrm{CMB}$ & & 4 & Onehot & 0.8441 & (CMB) Urinary tract infection or pyelonephritis \\
\hline CMBJ03 & $\mathrm{CMB}$ & & 4 & Onehot & 0.8441 & (CMB) Sepsis \\
\hline CMBJ04 & $\mathrm{CMB}$ & & 4 & Onehot & 0.8422 & $\begin{array}{l}\text { (CMB) Pneumonia } \\
\text { (CMB) Other maternal infections }\end{array}$ \\
\hline CMBJ05 & $\mathrm{CMB}$ & & 4 & Onehot & 0.8384 & $\begin{array}{l}\text { (e.g., viral, fungal, parasitic, spirochetal, } \\
\text { other bacterial), excluding bacterial vaginosis }\end{array}$ \\
\hline CMEA01 & $\mathrm{CME}$ & & 4 & Onehot & 0 & (CME) Urinary tract infection \\
\hline CMEA02 & CME & & 4 & Onehot & 0 & (CME) Sepsis \\
\hline CMEA03 & CME & & 4 & Onehot & 0 & $\begin{array}{l}\text { (CME) Pneumonia } \\
\text { (CME) Other maternal infections }\end{array}$ \\
\hline CMEA04 & $\mathrm{CME}$ & & 4 & Onehot & 0 & $\begin{array}{l}\text { (e.g., viral, fungal, parasitic, spirochetal, } \\
\text { other bacterial), excluding bacterial vaginosis }\end{array}$ \\
\hline GravCat & Demographics & & 1 & Mode & 0.001 & Gravidity category (V1AE01) \\
\hline oDM & $\begin{array}{l}\text { Pregnancy } \\
\text { outcomes }\end{array}$ & & 0 & Mode & 0.047 & $\begin{array}{l}\text { Diabetes based on CMAE03 \& glucose } \\
\text { tolerance testing results in CLA section E }\end{array}$ \\
\hline ChronHTN & $\begin{array}{l}\text { Pregnancy } \\
\text { outcomes }\end{array}$ & & 1 & Mode & 0.0567 & $\begin{array}{l}\text { Chronic hypertension based on CMDA01 } \\
\text { \& CMAE01 }\end{array}$ \\
\hline PEgHTN & $\begin{array}{l}\text { Pregnancy } \\
\text { outcomes }\end{array}$ & & 3 & Mode & 0.0568 & $\begin{array}{l}\text { Preeclampsia/Gestational HTN (worst) } \\
\text { using nuMoM2b criteria (CMDA08a) }\end{array}$ \\
\hline S02A01 & S02 & & 0 & Mean & 0 & $\begin{array}{l}\text { (S02) Total number of pregnancies including } \\
\text { current pregnancy - number of pregnancies }\end{array}$ \\
\hline $\mathrm{S} 02 \mathrm{C} 01$ & S02 & & 0 & Onehot & 0.0003 & (S02) Assisted reproduction for this pregnancy \\
\hline V1AD01b & $\mathrm{V} 1 \mathrm{~A}$ & & 1 & Mean & 0.0207 & $\begin{array}{l}\text { (V1A) How much did you weigh before you } \\
\text { got pregnant? - lbs }\end{array}$ \\
\hline V1AD12a & $\mathrm{V} 1 \mathrm{~A}$ & & 1 & Onehot & 0.0003 & $\begin{array}{l}\text { (V1A) Previous surgeries - } \\
\text { Cervical surgery - cone }\end{array}$ \\
\hline V1AD12b & $\mathrm{V} 1 \mathrm{~A}$ & & 1 & Onehot & 0.0003 & $\begin{array}{l}\text { (V1A) Previous surgeries - } \\
\text { Cervical surgery - LEEP }\end{array}$ \\
\hline V1AD12c & $\mathrm{V} 1 \mathrm{~A}$ & & 1 & Onehot & 0.0003 & $\begin{array}{l}\text { (V1A) Previous surgeries - } \\
\text { Cervical surgery - Cryotherapy } \\
\text { (VXX) Medical conditions or diagnoses, }\end{array}$ \\
\hline VXXB01aa_FA & vXx & & 4 & Onehot & 0 & $\begin{array}{l}\text { High blood pressure (hypertension) - } \\
\text { Final Assessment: Condition present }\end{array}$ \\
\hline VXXB01ab_FA & vXX & & 4 & Onehot & 0 & $\begin{array}{l}\text { (VXX) Medical conditions or diagnoses, } \\
\text { Asthma - Final Assessment: Condition present }\end{array}$ \\
\hline VXXB01ac_FA & vXX & & 4 & Onehot & 0 & $\begin{array}{l}\text { (VXX) Medical conditions or diagnoses, Seizure } \\
\text { disorder - Final Assessment: Condition present } \\
\text { (VXX) Medical conditions or diagnoses, }\end{array}$ \\
\hline VXXB01ad_FA & VXX & & 4 & Onehot & 0 & $\begin{array}{l}\text { Migraine headaches - } \\
\text { Final Assessment: Condition present }\end{array}$ \\
\hline VXXB01ae_FA & vXX & & 4 & Onehot & 0 & $\begin{array}{l}\text { (VXX) Medical conditions or diagnoses, } \\
\text { Diabetes (excluding gestational } \\
\text { diabetes in a prior pregnancy) - } \\
\text { Final Assessment: Condition present }\end{array}$ \\
\hline
\end{tabular}




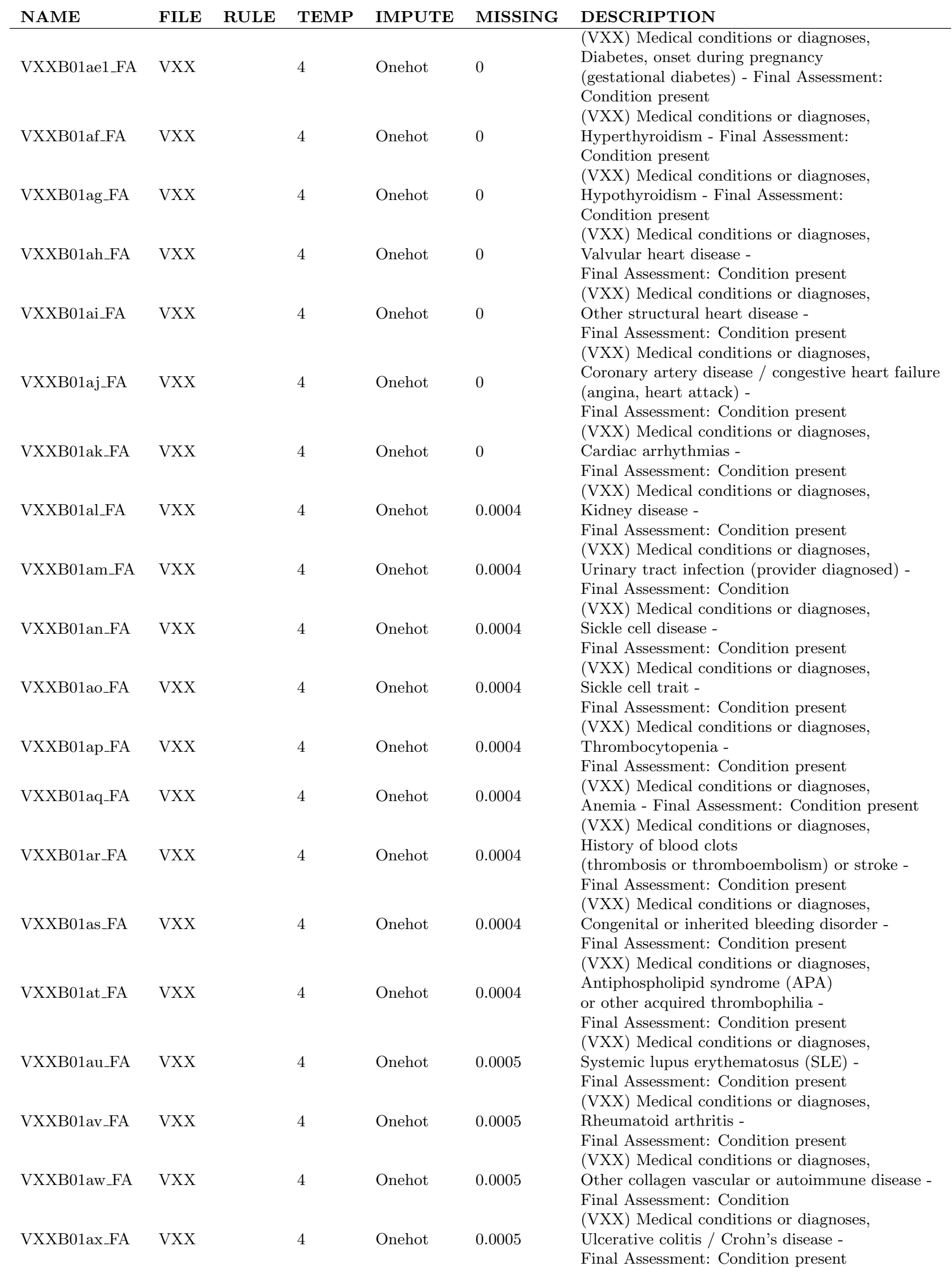




\begin{tabular}{|c|c|c|c|c|c|c|}
\hline NAME & FILE & RULE & TEMP & IMPUTE & MISSING & DESCRIPTION \\
\hline VXXB01ay_FA & VXX & & 4 & Onehot & 0.0005 & $\begin{array}{l}\text { (VXX) Medical conditions or diagnoses, } \\
\text { Cholestasis of pregnancy - } \\
\text { Final Assessment: Condition present }\end{array}$ \\
\hline VXXB01az_FA & VXX & & 4 & Onehot & 0.0005 & $\begin{array}{l}\text { (VXX) Medical conditions or diagnoses, } \\
\text { Liver/gall bladder disease - } \\
\text { Final Assessment: Condition present }\end{array}$ \\
\hline VXXB01ba_FA & VXX & & 4 & Onehot & 0.0005 & $\begin{array}{l}\text { (VXX) Medical conditions or diagnoses, } \\
\text { Cancer (malignancy) - } \\
\text { Final Assessment: Condition present }\end{array}$ \\
\hline VXXB01bb_FA & VXX & & 4 & Onehot & 0.0005 & $\begin{array}{l}\text { (VXX) Medical conditions or diagnoses, } \\
\text { Mental health condition - } \\
\text { Final Assessment: Condition present } \\
\text { (VXX) Medical conditions or diagnoses, }\end{array}$ \\
\hline VXXB01bc1_FA & vXX & & 4 & Onehot & 0.0005 & $\begin{array}{l}\text { Gynecological Conditions, Cervical dysplasia - } \\
\text { Final Assessment: Condition Present } \\
\text { (VXX) Medical conditions or diagnoses, }\end{array}$ \\
\hline VXXB01bc2_FA & VXX & & 4 & Onehot & 0.0005 & $\begin{array}{l}\text { Gynecological Conditions, Fibroids - } \\
\text { Final Assessment: Condition present } \\
\text { (VXX) Medical conditions or diagnoses, }\end{array}$ \\
\hline VXXB01bc3_FA & VXX & & 4 & Onehot & 0.0005 & $\begin{array}{l}\text { Gynecological Conditions, Polycystic ovary disease } \\
\text { (PCOS) - Final Assessment: Condition present } \\
\text { (VXX) Medical conditions or diagnoses, }\end{array}$ \\
\hline VXXB01bd1_FA & VXX & & 4 & Onehot & 0.0005 & $\begin{array}{l}\text { Sexually transmitted diseases, Gonorrhea - } \\
\text { Final Assessment: Condition present } \\
\text { (VXX) Medical conditions or diagnoses, }\end{array}$ \\
\hline VXXB01bd2_FA & VXX & & 4 & Onehot & 0.0005 & $\begin{array}{l}\text { Sexually transmitted diseases, } \\
\text { Chlamydia - Final Assessment: Condition present } \\
\text { (VXX) Medical conditions or diagnoses, }\end{array}$ \\
\hline VXXB01bd3_FA & VXX & & 4 & Onehot & 0.0005 & $\begin{array}{l}\text { Sexually transmitted diseases, } \\
\text { Herpes - Final Assessment: Condition present } \\
\text { (VXX) Medical conditions or diagnoses, }\end{array}$ \\
\hline VXXB01bd4_FA & VXX & & 4 & Onehot & 0.0005 & $\begin{array}{l}\text { Sexually transmitted diseases, } \\
\text { Syphilis - Final Assessment: Condition present } \\
\text { (VXX) Medical conditions or diagnoses, }\end{array}$ \\
\hline VXXB01bd5_FA & VXX & & 4 & Onehot & 0.0005 & $\begin{array}{l}\text { Sexually transmitted diseases, HIV/AIDS - } \\
\text { Final Assessment: Condition } \\
\text { (VXX) Medical conditions or diagnoses, }\end{array}$ \\
\hline VXXB01bd6_FA & VXX & & 4 & Onehot & 0.0005 & $\begin{array}{l}\text { Sexually transmitted diseases, } \\
\text { Hepatitis B - Final Assessment: Condition } \\
\text { (VXX) Medical conditions or diagnoses, }\end{array}$ \\
\hline VXXB01bd7_FA & VXX & & 4 & Onehot & 0.0005 & $\begin{array}{l}\text { Sexually transmitted diseases, Hepatitis C - } \\
\text { Final Assessment: Condition } \\
\text { (VXX) Medical conditions or diagnoses, }\end{array}$ \\
\hline VXXB01bd8_FA & VXX & & 4 & Onehot & 0.0005 & $\begin{array}{l}\text { Sexually transmitted diseases, Trichomonas - } \\
\text { Final Assessment: Condition } \\
\text { (VXX) Medical conditions or diagnoses, }\end{array}$ \\
\hline VXXB01bd9_FA & VXX & & 4 & Onehot & 0.0005 & $\begin{array}{l}\text { Sexually transmitted diseases, Other - } \\
\text { Final Assessment: Condition present } \\
\text { (VXX) Medical conditions or diagnoses, }\end{array}$ \\
\hline VXXB01be_FA & VXX & & 4 & Onehot & 0.0005 & $\begin{array}{l}\text { Yeast infection (provider diagnosed) - } \\
\text { Final Assessment: Condition present } \\
\text { (VXX) Medical conditions or diagnoses, }\end{array}$ \\
\hline VXXB01bf_FA & VXX & & 4 & Onehot & 0.0005 & $\begin{array}{l}\text { Bacterial vaginosis - } \\
\text { Final Assessment: Condition present }\end{array}$ \\
\hline GEST_AGE_LOSS & S02 & GEST_AGE & 0 & 0 & & \\
\hline S02A01a_1 & S02 & & 0 & & 0.8565 & $\begin{array}{l}\text { (S02) Pregnancy \#1 - Gestational age at } \\
\text { time of loss, weeks }\end{array}$ \\
\hline S02A01b_1 & S02 & & 0 & & 0.8892 & $\begin{array}{l}\text { (S02) Pregnancy \#1 - Gestation age at } \\
\text { time of loss }\end{array}$ \\
\hline S02A02_1 & S02 & & 0 & & 0.7489 & $\begin{array}{l}\text { (S02) Pregnancy \#1 - Spontaneous } \\
\text { delivery or miscarriage }\end{array}$ \\
\hline S02A01a_2 & S02 & & 0 & & 0.9641 & $\begin{array}{l}\text { (S02) Pregnancy \#2 - Gestational age } \\
\text { at time of loss, weeks }\end{array}$ \\
\hline
\end{tabular}


medRxiv preprint doi: https://doi.org/10.1101/2021.08.24.21262142; this version posted August 26, 2021. The copyright holder for this preprint (which was not certified by peer review) is the author/funder, who has granted medRxiv a license to display the preprint in perpetuity.

It is made available under a CC-BY-NC-ND 4.0 International license .

\subsection{Outcomes}

The outcomes filtering concerns post-pregnancy analysis of the newborn (all kinds of delivery), and variables that are highly predictive of preterm birth, such as major fetal conditions. Some of these variables may be used as class labels, such as pOUTCOME or GAwksEND, and others may provide privileged information for certain models. The vast majority of this data is highly prone to class leakage and should not be used in modeling, but is used for data analysis. Provided in the table are a sample of features that are useful in data analysis or as class labels.

Total \# Features: 1165

Relevant Files: CBA, CBB, CBC, CMA, CMC, CPA, pregnancy_outcomes, S02, U02, U2A, U3A, V4A

\begin{tabular}{|c|c|c|c|c|c|}
\hline NAME & FILE & RULE & TEMPORAL IMPUTE & MISSING & DESCRIPTION \\
\hline CBAA04a & CBA & & 5 & 0.0051 & (CBA) Apgar scores - One minute \\
\hline CBAA04a_Check & CBA & & 5 & 0 & (CBA) Apgar scores - One minute, not available \\
\hline CBAA04b & CBA & & 5 & 0.0054 & (CBA) Apgar scores - Five minute \\
\hline CBAA04b_Check & CBA & & 5 & 0 & (CBA) Apgar scores - Five minute, not available \\
\hline CBAA04c & CBA & & 5 & 0.9609 & (CBA) Apgar scores - Ten minute \\
\hline CBAA04c_Check & CBA & & 5 & 0 & (CBA) Apgar scores - Ten minute, not available \\
\hline bw & $\begin{array}{l}\text { pregnancy } \\
\text { _outcomes }\end{array}$ & & 5 & 0.0602 & $\begin{array}{l}\text { Birth weight in grams based on CBAA05 (for } \\
\text { livebirths) or CBCA04 (for stillbirths) }\end{array}$ \\
\hline CBAA02 & $\mathrm{CBA}$ & & $\begin{array}{l}5 \\
4\end{array}$ & 0.0013 & (CBA) Gender of baby or fetus \\
\hline pOUTCOME & $\begin{array}{l}\text { pregnancy } \\
\text { _outcomes }\end{array}$ & & 4 & 0.0352 & $\begin{array}{l}\text { Pregnancy outcome based on chart abstraction } \\
\text { \& A09 }\end{array}$ \\
\hline PROM & $\begin{array}{l}\text { pregnancy } \\
\text { _outcomes }\end{array}$ & & 4 & 0.0592 & $\begin{array}{l}\text { Premature rupture of membranes based on } \\
\text { CMAC06c \& CMAC06d }\end{array}$ \\
\hline SPONTANEOUS & $\begin{array}{l}\text { pregnancy } \\
\text { _outcomes }\end{array}$ & & 4 & 0.0546 & $\begin{array}{l}\text { Spontaneous or indicated based on PROM } \\
\text { and CMAC } 06\end{array}$ \\
\hline GAwksEND & $\begin{array}{l}\text { pregnancy } \\
\text { _outcomes }\end{array}$ & & 4 & 0.0374 & $\begin{array}{l}\text { Gestational age (weeks) at pregnancy end based } \\
\text { on S02F01 and both chart abstraction \& A09 }\end{array}$ \\
\hline TYPE_CA_A09 & $\begin{array}{l}\text { pregnancy } \\
\text { _outcomes }\end{array}$ & & 4 & 0 & $\begin{array}{l}\text { Type of livebirth/stillbirth based on chart abstraction } \\
\& \text { A09, derived from multiple outcome variables }\end{array}$ \\
\hline
\end{tabular}




\subsection{Treatment}

The treatment filtering contains features that pertain to drug administration directly related to delivery or the prevention of preterm birth. This includes administration of steroids for fetal lung maturation, tocolytics, progesterone, and various classes of drugs used specifically for delivery. These features are highly predictive of PTB, and are thus only used for analysis or sequential treatment decision making. Shown is a sample of these features.

Total \# Features: 149

Layer 1 \# Features: N/A (27 Available)

Layer 2 \# Features: N/A (34 Available)

Relevant Files: CMA

Dropped Features: For this group, there was much metadata that was used to place the administration within a particular time point, and then later dropped. Medication codes were used instead of names. Details on which particular drug within a class was used were dropped in L1, as the intended and possible effect were known and similar. Anticonvulsant details were returned in L2 as they can have dramatic differences.

\begin{tabular}{|c|c|c|c|c|c|c|}
\hline NAME & FILE & RULE & TEMPORAL & IMPUTE & MISSINGNESS & DESCRIPTION \\
\hline CMAF01 & CMA & & Date Abstraction & ANY & 0.002 & $\begin{array}{l}\text { (CMA) Did the Participant receive steroids for fetal lung } \\
\text { maturation at any time during this pregnancy? }\end{array}$ \\
\hline CMAF02 & CMA & & Date Abstraction & ANY & 0.0023 & $\begin{array}{l}\text { (CMA) Did the Participant receive progesterone at any } \\
\text { time during this pregnancy? }\end{array}$ \\
\hline CMAF01a & CMA & & Date Abstraction & ANY & 0.0011 & (CMA) Steroids for fetal lung maturation: Betamethasone \\
\hline CMAF01a3 & CMA & & Date Abstraction & ANY & 0.9544 & $\begin{array}{l}\text { (CMA) Steroids for fetal lung maturation: Betamethasone } \\
\text { - Total number of injections given over pregnancy }\end{array}$ \\
\hline CMAF01b & CMA & & Date Abstraction & ANY & 0.0011 & $\begin{array}{l}\text { (CMA) Steroids for fetal lung maturation: Dexamethasone } \\
\text { - Dexamethasone }\end{array}$ \\
\hline CMAF01b3 & CMA & & Date Abstraction & ANY & 0.9992 & $\begin{array}{l}\text { (CMA) Steroids for fetal lung maturation: Dexamethasone } \\
\text { - Total number of doses given over pregnancy }\end{array}$ \\
\hline CMAF02a & CMA & & Date Abstraction & 999 & 0.981 & (CMA) Progesterone vehicle of administration: \\
\hline CMAF02a_sp & CMA & & Date Abstraction & 999 & 0.9979 & $\begin{array}{l}\text { (CMA) Progesterone vehicle of administration: - Other, } \\
\text { specify }\end{array}$ \\
\hline CMAF02b1 & CMA & & Date Abstraction & -1 & 0.9979 & (CMA) Progesterone dose - \% \\
\hline CMAF02b2 & CMA & & Date Abstraction & -1 & 0.989 & (CMA) Progesterone dose - mg \\
\hline CMAF02c & CMA & & Date Abstraction & 0 & 0.9743 & (CMA) Progesterone frequency of administration \\
\hline CMAF02c_sp & CMA & & Date Abstraction & 999 & 0.9875 & $\begin{array}{l}\text { (CMA) Progesterone frequency of administration - Other, } \\
\text { specify }\end{array}$ \\
\hline CMAG01 & CMA & & 4 & ANY & 0.0021 & $\begin{array}{l}\text { (CMA) Did the Participant receive tocolysis at any time } \\
\text { during this hospitalization for delivery? }\end{array}$ \\
\hline CMAG02 & CMA & & 4 & ANY & 0.0021 & $\begin{array}{l}\text { (CMA) Were antibiotics used anytime during this } \\
\text { hospitalization for delivery? }\end{array}$ \\
\hline CMAG03 & CMA & & 4 & ANY & 0.002 & $\begin{array}{l}\text { (CMA) Were antihypertensives used anytime during this } \\
\text { hospitalization for delivery? }\end{array}$ \\
\hline CMAG04 & CMA & & 4 & ANY & 0.002 & $\begin{array}{l}\text { (CMA) Were anticonvulsants used anytime during this } \\
\text { hospitalization for delivery? }\end{array}$ \\
\hline CMAG05 & CMA & & 4 & ANY & 0.0018 & $\begin{array}{l}\text { (CMA) Was magnesium sulfate given specifically for } \\
\text { neuroprophylaxis anytime during this hospitalization } \\
\text { for delivery? }\end{array}$ \\
\hline CMAG06 & CMA & & 4 & ANY & 0.0021 & $\begin{array}{l}\text { (CMA) Were any other prescribed medications used } \\
\text { during this hospitalization for delivery? }\end{array}$ \\
\hline CMAG06a & CMA & & 4 & 2 & 0.0011 & $\begin{array}{l}\text { (CMA) Other prescribed medications used during this } \\
\text { hospitalization for delivery - Insulin }\end{array}$ \\
\hline CMAG06b & CMA & & 4 & 2 & 0.0011 & $\begin{array}{l}\text { (CMA) Other prescribed medications used during this } \\
\text { hospitalization for delivery - Heparin / LMW heparin injection }\end{array}$ \\
\hline CMAG06c1 & CMA & & 4 & 777 & 0.7016 & $\begin{array}{l}\text { (CMA) Other prescribed medications used during this } \\
\text { hospitalization for delivery - Medication code }(1)\end{array}$ \\
\hline CMAG06d1 & CMA & & 4 & 777 & 0.871 & $\begin{array}{l}\text { (CMA) Other prescribed medications used during this } \\
\text { hospitalization for delivery - Medication code }(2)\end{array}$ \\
\hline CMAG06e1 & CMA & & 4 & 777 & 0.9373 & $\begin{array}{l}\text { (CMA) Other prescribed medications used during this } \\
\text { hospitalization for delivery - Medication code }(3)\end{array}$ \\
\hline CMAG06f1 & CMA & & 4 & 777 & 0.9667 & $\begin{array}{l}\text { (CMA) Other prescribed medications used during this } \\
\text { hospitalization for delivery - Medication code }(4)\end{array}$ \\
\hline CMAG06g1 & CMA & & 4 & 777 & 0.9821 & $\begin{array}{l}\text { (CMA) Other prescribed medications used during this } \\
\text { hospitalization for delivery - Medication code }(5)\end{array}$ \\
\hline CMAG06h1 & CMA & & 4 & 777 & 0.9888 & $\begin{array}{l}\text { (CMA) Other prescribed medications used during this } \\
\text { hospitalization for delivery - Medication code }(6)\end{array}$ \\
\hline CMAG06i1 & CMA & & 4 & 777 & 0.9935 & $\begin{array}{l}\text { (CMA) Other prescribed medications used during this } \\
\text { hospitalization for delivery - Medication code }(7)\end{array}$ \\
\hline
\end{tabular}




\subsection{Food Frequency Analysis}

The food frequency analysis file takes into account the food and nutrients consumed by patients in the 3 months prior to conception. We were most interested in the calculated nutrient intake as opposed to less interpretable data like grams of food consumed or food pyramid group quantities. In addition to nutrients, we also attempted to capture the overall energy intake by using glycemic load and calorie intake as proxies.

Total Features: 737

Layer 1 Features: 38

Layer 2 Features: 38

Relevant Files: food_frequency_analysis (ancillary)

Dropped Features: For this group, we dropped the features that contained redundant information about food intake that was already captured by the vitamin amounts. For instance, quantities of food items such as "glasses of milk" would be reflected in the overall vitamin and calorie consumption.

Table 10: Food Frequency Filtering

\begin{tabular}{|c|c|c|c|c|c|c|}
\hline NAME & FILE & RULE & TEMPORAL & IMPUTE & MISSING & DESCRIPTION \\
\hline GL & food frequency analysis & & 0 & mean & 0 & Glycemic Load \\
\hline DT_KCAL & food frequency analysis & & 0 & mean & 0 & KCAL Total \\
\hline DT_THEOB & food frequency analysis & & 0 & mean & 0 & Theobromine, mg, average daily \\
\hline FOL_DFE & food frequency analysis & & 0 & mean & 0 & $\begin{array}{l}\text { Average daily Dietary Folate } \\
\text { Equivalents, mcg }\end{array}$ \\
\hline DT_METHI & food frequency analysis & & 0 & mean & 0 & Methionine (S-containing), grams \\
\hline DT_CALC & food frequency analysis & & 0 & mean & 0 & Calcium, mg \\
\hline DT_IRON & food frequency analysis & & 0 & mean & 0 & Iron, mg \\
\hline DT_MAGN & food frequency analysis & & 0 & mean & 0 & Magnesium, mg \\
\hline DT_PHOS & food frequency analysis & & 0 & mean & 0 & Phosphorus, mg \\
\hline DT_POTA & food frequency analysis & & 0 & mean & 0 & Potassium, mg \\
\hline DT_SODI & food frequency analysis & & 0 & mean & 0 & Sodium, mg \\
\hline DT_ZINC & food frequency analysis & & 0 & mean & 0 & Zinc, mg \\
\hline DT_COPP & food frequency analysis & & 0 & mean & 0 & Copper, mg \\
\hline DT_SEL & food frequency analysis & & 0 & mean & 0 & Selenium, mcg \\
\hline DT_VARAE & food frequency analysis & & 0 & mean & 0 & $\begin{array}{l}\text { Vitamin A Retinol Activity } \\
\text { Equivalents (RAE), mcg }\end{array}$ \\
\hline DT_RET & food frequency analysis & & 0 & mean & 0 & Retinol, mcg \\
\hline DT_ACARO & food frequency analysis & & 0 & mean & 0 & Alpha-carotene, mcg \\
\hline DT_BCARO & food frequency analysis & & 0 & mean & 0 & Beta-carotene, mcg \\
\hline DT_CRYPT & food frequency analysis & & 0 & mean & 0 & Cryptoxanthin, mcg \\
\hline DT_LYCO & food frequency analysis & & 0 & mean & 0 & Lycopene, mcg \\
\hline DT_LUTZE & food frequency analysis & & 0 & mean & 0 & Lutein-Zeaxanthin, mcg \\
\hline DT_ATOC & food frequency analysis & & 0 & mean & 0 & Vitamin E as alpha-tocopherol, $\mathrm{mg}$ \\
\hline DT_VITC & food frequency analysis & & 0 & mean & 0 & Vitamin $\mathrm{C}, \mathrm{mg}$ \\
\hline DT_THIA & food frequency analysis & & 0 & mean & 0 & Thiamin (Vitamin B1), mg \\
\hline DT_RIBO & food frequency analysis & & 0 & mean & 0 & Riboflavin (Vitamin B2), mg \\
\hline DT_NIAC & food frequency analysis & & 0 & mean & 0 & Niacin, $\mathrm{mg}$ \\
\hline DT_VITB6 & food frequency analysis & & 0 & mean & 0 & Vitamin B6, mg \\
\hline DT_VB12 & food frequency analysis & & 0 & mean & 0 & Vitamin B-12, mcg \\
\hline DT_VITK & food frequency analysis & & 0 & mean & 0 & Vitamin $\mathrm{K}$ as phylloquinone, mcg \\
\hline DT_FA182 & food frequency analysis & & 0 & mean & 0 & Dietary PUFA $(\sim \mathrm{N}-6) 18: 2$, grams \\
\hline DT_FA183 & food frequency analysis & & 0 & mean & 0 & Dietary PUFA $(\sim \mathrm{N}-3) 18: 3$, grams \\
\hline DT_FA184 & food frequency analysis & & 0 & mean & 0 & Dietary PUFA $18: 4$, grams \\
\hline DT_FA204 & food frequency analysis & & 0 & mean & 0 & Dietary PUFA ( N-6) 20:4, grams \\
\hline DT_FA205 & food frequency analysis & & 0 & mean & 0 & Dietary N-3 PUFA 20:5 (EPA), grams \\
\hline DT_FA225 & food frequency analysis & & 0 & mean & 0 & Dietary N-3 PUFA 22:5 (DPA), grams \\
\hline DT_FA226 & food frequency analysis & & 0 & mean & 0 & Dietary N-3 PUFA 22:6 (DHA), grams \\
\hline DT_TOTN6 & food frequency analysis & & 0 & mean & 0 & Avg. daily omega- 6 FA, grams \\
\hline DT_TOTN3 & food frequency analysis & & 0 & mean & 0 & Avg. daily omega-3 FA, grams \\
\hline
\end{tabular}


medRxiv preprint doi: https://doi.org/10.1101/2021.08.24.21262142; this version posted August 26, 2021. The copyright holder for this preprint (which was not certified by peer review) is the author/funder, who has granted medRxiv a license to display the preprint in perpetuity.

It is made available under a CC-BY-NC-ND 4.0 International license .

\subsection{Sleep Substudy}

The sleep substudy filtering includes sleep quantity and quality by calculating the average hours slept per night as well as sleep apnea diagnoses.

Total Features: 6

Layer 1 Features: 4

Layer 2 Features: 6

Relevant Files: V1L, V3L

Dropped Features: Due to sleep being a separate substudy, only a few features were selected to be included. The rest were dropped as of writing.

Table 11: Sleep Substudy Filtering

\begin{tabular}{|c|c|c|c|c|c|c|}
\hline NAME & FILE & RULE & TEMPORAL & IMPUTE & MISSING & DESCRIPTION \\
\hline V1LF01a & V1L & & 1 & Onehot & 0.00514 & $\begin{array}{l}\text { Have you ever been told by a doctor } \\
\text { or other health professionals that you } \\
\text { have sleep apnea or obstructive sleep apnea? }\end{array}$ \\
\hline V3LF01a & V3L & & 3 & Onehot & 0.00464 & $\begin{array}{l}\text { Have you ever been told by a doctor } \\
\text { or other health professionals that you } \\
\text { have sleep apnea or obstructive sleep apnea? }\end{array}$ \\
\hline V1A_SLEEP & V1L & SLEEP_AVG & 1 & Mean & & \\
\hline V1LA02a & V1L & & 1 & & 0.00463 & $\begin{array}{l}\text { How many hours of sleep do you } \\
\text { usually get per night: } \\
\text { On weekdays or workdays? }\end{array}$ \\
\hline V1LA02b & V1L & & 1 & & 0.00463 & $\begin{array}{l}\text { How many hours of sleep do you } \\
\text { usually get per night: On weekends? }\end{array}$ \\
\hline V3A_SLEEP & V3L & SLEEP_AVG & 3 & Mean & & \\
\hline V3LA02a & V3L & & 3 & & 0.00357 & $\begin{array}{l}\text { How many hours of sleep do you } \\
\text { usually get per night: } \\
\text { On weekdays or workdays? }\end{array}$ \\
\hline V3LA02b & V3L & & 3 & & 0.00357 & $\begin{array}{l}\text { How many hours of sleep do you } \\
\text { usually get per night: On weekends? }\end{array}$ \\
\hline
\end{tabular}

\subsection{Genetic data}

The genotyped cohort comprises 9,757 nulliparous women from the nuMoM2b study who had adequate samples and agreed to be genotyped. DNA extractions from whole blood, which had been frozen at $-80^{\circ}$, were carried out on a Qiasymphony instrument at the Center for Bioinformatics and Genomics (Indiana University). Genotyping was done at the Van Andel Institute (Grand Rapids, MI, USA) using the Infinium Multi-Ethnic Global D2 BeadChip (Illumina, Miami, USA). We imposed standard filters for quality control of loci at this stage (cluster separation $<0.3$, AA R Mean $<0.2$, AB R Mean $<0.2$, BB R Mean $<0.2,10 \%$ GC $<0.3)$ using GenomeStudio v2.4 (Illumina). Genotype calls (in .GCT format) for the 1,748,280 loci that passed initial quality control were made with Beeline autoconvert (Ilumina).

\section{Lessons Learned and Discussion}

The main goals of the data preprocessing of the nuMoM2b dataset were to get a deeper understanding of the data, extract the most relevant features, and reduce the dimensionality of the data. Additionally, we wanted to make the fewest assumptions when filling in unknown values, and to understand the intricacies behind the dependencies present in the data.

The original ratio of features to patients of around 4,600 to 10,000 is too high to create reliable models because of the high possibility of over-fitting in a high dimensional space. Therefore, it was crucial for the interdisciplinary team to work together to leverage medical expertise, computing and statistics skills in order to gain a good grasp 
medRxiv preprint doi: https://doi.org/10.1101/2021.08.24.21262142; this version posted August 26, 2021. The copyright holder for this preprint (which was not certified by peer review) is the author/funder, who has granted medRxiv a license to display the preprint in perpetuity. It is made available under a CC-BY-NC-ND 4.0 International license.

of the wealth of information in the nuMoM2b dataset. The data preprocessing team worked to make sure that any medical assumptions, such as grouping related conditions together or deciding to drop select details, were approved by the medical experts.

It was equally crucial to understand the protocol that doctors follow in the administration of interventions. Debates about definitions, classification of conditions, and treatments exist and were taken into consideration. A notable example is the debate around the usage of progesterone as an intervention for preterm birth. Another is simply the definitions of spontaneous and indicated preterm birth and how the events that fall under those categories may have changed over time.

With regards to the data itself, the most significant challenges were understanding the dependencies between different features and their medical relevance to preterm birth. The data includes both patient interviews and abstractions from the patients' charts. Sometimes the questions overlapped, other times they were parallel, or had features that combined information from both. Each source has a different level of relevance in building the models.

Standardization of data formatting was another obstacle. Much of the original labeling and information provided in the codebooks was not sufficient to directly begin the modeling process. For instance, labels such as variable type had to be manually added. It was also important to determine when specific data were relevant and when they were collected. For example, for data that were not collected exactly within the strict time designations for Visits 1 through 4, the associated dates were computed relative to the estimated date for the start of pregnancy. Manual inspection was also required when coded values of responses did not match the information shown in the data collection forms. Codings such as Don't Know, or Refused response did not exist in the data even though they were mentioned in the codebooks.

Throughout the preprocessing, we aimed to make the filtering and imputation steps as systematic as possible, while organizing the data into medically homogeneous groups. The discussion here is merely a glimpse of the intended goals and actions taken during the preprocessing. As our team delves into the PTB-related research goals, we anticipate that more preprocessing will be required on specific data.

\section{Institutional review board statement and funding sources}

Human subjects approval for this study, titled "SCH: Prediction of Preterm Birth in Nulliparous Women", was obtained following review by Columbia University Human Subjects Institutional Review Board under number IRB-AAAR9413, and the City University of New York CUNY HRPP/IRB review number 2019-0855. Human subjects training requirements were completed by all authors of this study.

This work is supported by NIH/NLM (www.nlm.nih.gov) grant R01LM013327.

\section{References}

[1] http://www.nichd.nih.gov/research/supported/Pages/nuMoM2b.aspx.

[2] Clinical Informatics Group. Data pre-processing for the preterm prediction study MFMU dataset. http: //www.cs. columbia.edu/ ansaf/cing/CCLS-13-04.pdf, 2013.

[3] David Haas et al. A description of the methods of the nulliparous pregnancy outcomes study: monitoring mothers-to-be (numom2b). American Journal of Obstetrics and Gynecology, 212(4):539.e1-539.e24, 2015.

[4] Ilia Vovsha, Ashwath Rajan, Ansaf Salleb-Aouissi, Anita Raja, Axinia Radeva, Hatim Diab, Ashish Tomar, and Ronald Wapner. Predicting preterm birth is not elusive: Machine learning paves the way to individual wellness, 2014.

[5] Ilia Vovsha, Ansaf Salleb-Aouissi, Anita Raja, Thomas Koch, Alex Rybchuk, Axinia Radeva, Ashwath Rajan, Yiwen Huang, Hatim Diab, Ashish Tomar, and Ronald Wapner. Using kernel methods and model selection for prediction of preterm birth. In Finale Doshi-Velez, Jim Fackler, David Kale, Byron Wallace, and Jenna Wiens, editors, Proceedings of the 1st Machine Learning for Healthcare Conference, volume 56 of Proceedings of Machine Learning Research, pages 55-72, Children's Hospital LA, Los Angeles, CA, USA, 18-19 Aug 2016. PMLR. 